Contract No. W-7405-eng-92

\title{
DEVELOPMENT OF NIOBIUM-URANIUM ALLOYS \\ FOR ELEVATED-TEMPERATURE \\ FUEL APPLICATIONS
}

by

John A. DeMastry

Donald P. Moak

Seymour G. Epstein

Arthur A. Bauer

Ronald F. Dickerson

August 9, 1961

BATTELLE MEMORIAL INSTITUTE

$505 \mathrm{King}$ Avenue

Columbus 1, Ohio 


\section{DISCLAIMER}

This report was prepared as an account of work sponsored by an agency of the United States Government. Neither the United States Government nor any agency Thereof, nor any of their employees, makes any warranty, express or implied, or assumes any legal liability or responsibility for the accuracy, completeness, or usefulness of any information, apparatus, product, or process disclosed, or represents that its use would not infringe privately owned rights. Reference herein to any specific commercial product, process, or service by trade name, trademark, manufacturer, or otherwise does not necessarily constitute or imply its endorsement, recommendation, or favoring by the United States Government or any agency thereof. The views and opinions of authors expressed herein do not necessarily state or reflect those of the United States Government or any agency thereof. 


\section{DISCLAIMER}

Portions of this document may be illegible in electronic image products. Images are produced from the best available original document. 
ABSTRACT . . . . . . . . . . . . . . . . . . . . . . . 1

INTRODUCTION • . . . . . . . . . . . . . . . . . . . . . . 1

ALLOY PREPARATION BY ARC CASTING . . . . . . . . . . . . . 2

FABRICATION STUDIES OF ARC-CAST ALLOYS • . . . . . . . . . . 4

Flat Rolling . . . . . . . . . . . . . . . . . . . 5

Hot Forging . . . . . . . . . . . . . . . . . . . 5

Rod Rolling . . . . . . . . . . . . . . . . . . . 6

CONSUMABLE-ELECTRODE SKULL-CASTING STUDIES ～• • . . . . . $\quad 9$

Melting Studies . . . . . . . . . . . . . . . . . . 12

FABRICATION STUDIES OF SKULL-CAST ALLOYS . • . . . . . . . 15

MECHANICAL-PROPERTY DETERMINATIONS . . . . . . . . . . . 22

Elevated-Temperature Short-Time Tensile Tests . . . . . . . . 22

Creep Studies . . . . . . . . . . . . . . . . . . . 26

CORROSION-TEST RESULTS . . . . . . . . . . . . . . . . . . . . 31

In NaK and Sodium . . . . . . . . . . . . . . . . . . 31

In Water. . . . . . . . . . . . . . . . . . . . . 38

PHYSICAL-PROPERTY DETERMINATIONS . . . . . . . . . . . . 52

Thermal-Conductivity Measurements . . . . . . . . . . . 52

Electrical-Resistivity Measurements . . . . . . . . . . . . 52

Thermal-Expansion Measurements . . . . . . . . . . . . 55

Recrystallization Studies . . . . . . . . . . . . . . . 55

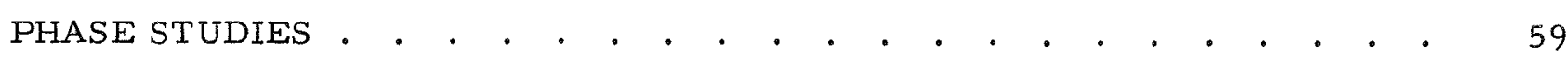

CONCLUSIONS • • . . . . . . . . . . . . . . . . . . . . . . . . . . 61

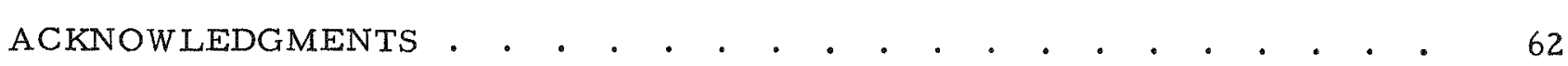

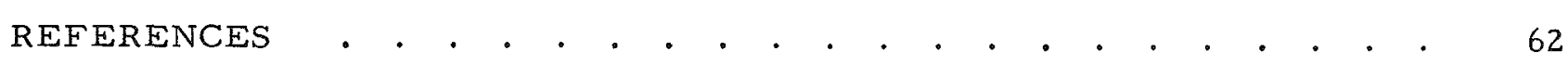




\section{DEVELOPMENT OF NIOBIUM-URANIUM ALLOYS FOR ELEVATED-TEMPERATURE FUEL APPLICATIONS}

John A. DeMastry, Donald P. Moak, Seymour G. Epstein, Arthur A. Bauer, and Ronald F. Dickerson

As a continuation of studies reported in BMI-1400, fabrication characieristics, physical and mechanical properties, and corrosion behavior in NaK, sodium, and water of niobiumuranium binary alloys containing up to $60 \mathrm{w} / \mathrm{o}$ uranium were investigated.

Alloys were cast by a skull melting and consumable and nonconsumable arcmelting methods. Fabrication difficulties with alloys containing greater than $25 \mathrm{w} / \mathrm{o}$ uranium were related to coring-type microsegregation during casting.

Tensile tests indicated 0.2 per cent offset yield strengths of $16,880,22,370$, and 28,600 psi for niobium-4.38, -14.3 , and $-20 \mathrm{w} / \mathrm{o}$ uranium alloys, respectively, at $2000 \mathrm{~F}$. Additional tensile data were obtained for alloys from 1600 to $2400 \mathrm{~F}$. Stresses to produce minimum creep rates of $0.001,0.01$, and 0.1 per cent per hr at 1600, 1800, and $2000 \mathrm{~F}$ were also determined. Both tensile and creep strengths were found to be sensitive to oxygen content.

All alloys appeared compatible with $\mathrm{NaK}$ at $1600 \mathrm{~F}$ and with sodium at $1500 \mathrm{~F}$. In $600 \mathrm{~F}$ water, most of the alloys tested exhibited negligible weight changes after 336 days' exposure. Weight changes were greater after 140 days' exposure to $680 \mathrm{~F}$ water, but corrosion rates were considered satisfactory for a clad fuel.

The thermal and electrical conductivities of niobium are lowered by the addition of uranium, while the thermal-expansion characteristics are essentially unaffected.

Recrystallization temperatures for 90 per cent cold-reduced niobium-4.38, $-14.3,-20,-25.0$, and $-30 \mathrm{w} / \mathrm{o}$ uranium alloys are $2300,2300,2400,2300$, and $2200 \mathrm{~F}$, respectively.

No appreciable effect of oxygen contents ranging from 100 to $1000 \mathrm{ppm}$ was observed on the composition limits of the gamma immiscibility gap in the niobiumuranium system.

\section{INTRODUCTION}

Utilization of metallic fuel alloys at elevated temperatures is dependent upon the development of materials which have sufficient strength to resist gas pressure resulting from the accumulation of fission gases in the fuel. It is also desirable that such fuels possess sufficient strength at elevated temperature to minimize the need of structural support. The niobium-uranium system appeared to be a logical choice for development of high-temperature fuel alloys because niobium and uranium exhibit complete mutual solubility at elevated temperatures and also because niobium and niobium alloys exhibit excellent high-temperature strength. Consequently, a study was undertaken to determine whether niobium alloys containing 10 to $60 \mathrm{w} / 0$ uranium had the necessary qualifications of fabricability, elevated-temperature strength, compatibility with various reactor coolants, and thermal conductivity for a reactor fuel material. 
The results of initial investigations of the niobium-uranium alloy system were reported in BMI-1400. (1) The conclusions indicated that niobium-uranium alloys, especially the niobium-20 w/o uranium alloy, showed excellent potential as reactor fuels. Niobium-20 w/o uranium alloy ingots were fabricated in molybdenum cans to prevent oxidation during forging at $2500 \mathrm{~F}$. The alloy exhibited a 0.2 per cent offset yield strength at $1600 \mathrm{~F}$ of $58,100 \mathrm{psi}$ with 16 per cent reduction in area. The corrosion life in 600 and $680 \mathrm{~F}$ water, $750 \mathrm{~F}$ steam, and $1600 \mathrm{~F} \mathrm{NaK}$ was more than adequate for a fue $\mathrm{I}$ material. Alloys containing $30 \mathrm{w} / \mathrm{o}$ or more uranium were not fabricable by the techniques employed in this initial study, and the need for a more basic understanding of the fabrication characteristics of alloys was indicated.

The results of more detailed studies of niobium-uranium alloys are contained in this report. These results were obtained on alloy material prepared by three different casting techniques: nonconsumable inert-electrode arc melting, consumable-electrode arc melting, and consumable-electrode skull-casting techniques. Most of the property data were obtained on material prepared by conventional consumable-electrode arcmelting practices. Preparation and fabrication studies involving these materials are presented first in this report. Mechanical-property data were obtained on material prepared by consumable-electrode arc melting and by consumable-electrode skull-casting techniques. Since no significant effect of casting technique was noted on mechanical properties, such data from the different materials are reported in one section.

\section{ALLOY PREPARATION BY ARC CASTING}

The niobium used was obtained from three suppliers. Table 1 lists the analysis of the niobium which was used as the high-purity melting stock in the property studies. Niobium with two levels of zirconium contamination was also used to prepare material for property studies. Table 2 lists the analyses for niobium of high and low zirconium content. Table 3 lists analyses for niobium used to prepare alloys for rod-rolling fabrication studies, consumable-electrode skull-casting studies, and also for the investigation of the effect of oxygen on the gamma loop. The uranium used for melting stock was highquality biscuit which contained 27 ppm oxygen and 2.1 ppm hydrogen.

Both consumable-electrode and nonconsumable inert-electrode arc melting were employed in specimen preparation.

Electrodes for consumable-electrode arc melting were prepared by welding uranium strip (rolled to a cross-section area which when attached to the niobium would give the composition desired) onto the niobium bars in a dry box (helium atmosphere). After melting, the ingots were turned on a lathe, quartered, and rewelded into an electrode which was remelted. Final ingots weighed between 3 and $4 \mathrm{lb}$ each. The niobium shown in Tables 1 and 2 was used in the above operations. Ingots prepared as above containing 10 and $20 \mathrm{w} / \mathrm{o}$ uranium were then "canned" in molybdenum and forged at $2550 \mathrm{~F}$ to $1 / 2-$ in. -thick slabs. After forging, the slabs were decanned and rolled in air from a heliumatmosphere furnace at $1800 \mathrm{~F}$ to sheet material. This sheet material was vapor blasted to remove surface oxide and utilized in property determination.

(1) References at end. 
TABLE 1. CHEMICAL ANALYSIS OF HIGH-FURITY NIOBIUM MEITING STOCK(a) USED IN PROPERTY STUDIES

\begin{tabular}{lc}
\hline \multicolumn{1}{c}{ Element } & $\begin{array}{c}\text { Analysis, } \\
\text { w/o }\end{array}$ \\
\hline Niobium & 99.8 minimum \\
Oxygen & 0.009 to 0.030 \\
Nitrogen & 0.020 to 0.030 \\
Carbon & 0.003 to 0.013 \\
Titanium & 0.012 to 0.015 \\
Tantalum & 0.075 to 0.082 \\
Nickel & 0.001 to 0.005 \\
Tungsten & $<0.01$ \\
Zirconium & $<0.02$ \\
Iron & $<0.007$ \\
Aluminum & $<0.0001$ \\
Yttrium & $<0.01$ \\
Lead & $<0.001$ \\
Chromium & $<0.001$ \\
Cobalt & $<0.001$ \\
Molybdenum & $<0.020$ \\
Silicon & $<0.010$ \\
Boxon & $<0.0001$ \\
Cadmium & $<0.0001$ \\
Lithium & $<0.0001$ \\
& \\
\hline
\end{tabular}

(a) Obtained from Fansteel Metallurgical Corporation.

TABLE 2. CHEMICAL ANA LYSIS OF HIGH-AND LOW-ZIRCONIUM NIOBIUM(a) USED IN PROPERTY STUDIES

\begin{tabular}{lcc}
\hline & \multicolumn{2}{c}{ Analysis, w/o } \\
\cline { 2 - 3 } Element & $<0.001$ & High Zirconium \\
\hline & 0.027 & $<0.0001$ \\
Boron & 0.060 & 0.028 \\
Nitrogen & 0.070 & 0.058 \\
Oxygen & 0.070 & 0.060 \\
Tantalum & $<0.005$ & 0.070 \\
Titanium & 0.020 & $<0.005$ \\
Iron & 0.010 & 0.020 \\
Silicon & 0.17 & 0.010 \\
Zirconium & 99.53 & 0.74 \\
Niobium & & 99.01 \\
& & \\
\hline \hline
\end{tabular}

(a) Obtained from Kennametal, Inc. 
TABLE 3. CHEMICAL ANALYSIS OF NIOBIUM MELTING STOCK(a)

USED FOR ROD-ROLLING FABRICATION STUDIES, SKULL-CASTING STUDIES, AND INVESTIGATION OF EFFECT OF OXYGEN ON GAMMA LOOP

\begin{tabular}{lc}
\hline Element & $\begin{array}{c}\text { Analysis } \\
\text { wo }\end{array}$ \\
\hline Aluminum & $<0.0020$ \\
Boron & 0.0001 \\
Carbon & 0.004 \\
Cadmium & $<0.0005$ \\
Chromium & $<0.002$ \\
Copper & $<0.004$ \\
Iron & 0.012 \\
Lead & $<0.002$ \\
Magnesium & $<0.002$ \\
Manganese & $<0.002$ \\
Molybdenum & $<0.002$ \\
Nitrogen & 0.005 \\
Nickel & $<0.002$ \\
Niobium & $>99.8$ \\
Oxygen & 0.009 \\
Silicon & $<0.010$ \\
Tantalum & 0.054 \\
Tin & $<0.0002$ \\
Titanium & $<0.015$ \\
Vanadium & $<0.002$ \\
Tungsten & 0.030 \\
Zinc & $<0.002$ \\
& \\
\hline \hline
\end{tabular}

(a) Obtained from Wah Chang Corporation.

For inert-electrode arc melting the niobium shown in Table 3 was rolled into sheet at room temperature. This sheet was then nibbled into $1 / 2$-in. squares for melting stock. These nibbles were arc melted into buttons which were then cast into shapes for the rodrolling and phase studies.

\section{FABRICATION STUDIES OF ARC-CAST ALLOYS}

The fabrication of niobium-uranium alloys was investigated by rolling flat plates, by forging, and by rod rolling. Evaluation of fabrication results reported in BMI-1400(1) suggested that higher fabrication temperatures (above $2500 \mathrm{~F}$ ), alloying with zirconium, or possibly the use of surface lubricants such as glass could improve the fabrication characteristics of the niobium-uranium alloys. In order to evaluate fabricability at higher temperatures $(2400$ to $3000 \mathrm{~F})$ and the effects of zirconium additions, the following studies were conducted: (1) niobium containing $30 \mathrm{w} / 0$ or more uranium and 0,10 , and $20 \mathrm{w} / \mathrm{o}$ zirconium additions was forged at temperatures ranging from 2400 to $3000 \mathrm{~F}$; and 
(2) niobium containing 10,20 , and $30 \mathrm{w} / 0$ uranium and niobium-30 w/o uranium-10 and $-20 \mathrm{w} / \mathrm{o}$ zirconium alloys were fabricated by rod rolling. Rod-rolling and forging oper. ations were conducted on specimens which had been canned in molybdenum packs. All fabrication was conducted between 2100 and $3000 \mathrm{~F}$, inclusive. In addition to the above, the use of a lubricant was evaluated by flat rolling alloys containing $30,40,50$, and 60 w/o uranium in a protective envelope of molten glass at $2500 \mathrm{~F}$.

\section{Flat Rolling}

Sections of alloys containing 30,40,50, and $60 \mathrm{w} / \mathrm{o}$ uranium were cut from consumably arc-melted ingots and machined to rectangular slabs 1 by $3 / 4$ by $1 / 2$ in. In order to determine if lubricant on the surface would prevent excessive surface cracking experienced during rolling, these slabs were encased in glass. This encasement was accomplished by dipping the cold slabs into molten glass and allowing the "glass pack" to cool in air. The specimens appeared to be successfully coated as the glass adhered to the metal slabs when cooled to room temperature. The glass-coated slabs were heated to $2500 \mathrm{~F}$ and flat rolling was attempted.

It was found that the molten glass failed to adhere to any except the $30 \mathrm{w} / \mathrm{o}$ uranium alloy during rolling. The oxide on the surfaces of the niobium-uranium alloys, with the exception of the $30 \mathrm{w} / 0$ uranium alloy, was apparently incompatible with the molten glass and wetting between the glass and surface oxide did not occur. Although the $30 \mathrm{w} / 0$ uranium alloy was successfully coated by the glass, the fabrication was unsuccessful since surface cracking was encountered. No further attempts at fabrication utilizing glass as a lubricant we re made.

\section{Hot Forging}

Additions of 10 and $20 \mathrm{w} / \mathrm{o}$ zirconium were made to niobium-30, $-40,-50$, and $-60 \mathrm{w} / \mathrm{o}$ uranium alloys in an attempt to improve their fabrication characteristics. All ingots were prepared by consumable-electrode arc melting using niobium containing $300 \mathrm{ppm}$ oxygen and $20 \mathrm{ppm}$ zirconium. The finished ingots which weighed approximately $3 \mathrm{lb}$ and were $2 \mathrm{in}$. in diameter were cut into slabs $3 / 4 \mathrm{in}$. thick. These slabs were then encapsulated in molybdenum cans and end plates were welded onto the cans in an inertatmosphere dry box. These packs were then upset forged from a hydrogen-atmosphere furnace held at temperatures of 2400,2800 , and $3000 \mathrm{~F}$.

The results of this fabrication study are summarized in Table 4. It appears that the addition of zixconium results in slightly increased fabricability of the 30 and $40 \mathrm{w} / \mathrm{o}$ uranium alloys. However, more improvement in fabricability appears to be gained by the reduction of fabrication temperatures from 3000 to $2400 \mathrm{~F}$. A more thorough investigation of the effects of lower working temperatures on the fabricability appeared to be advisable and rod rolling was selected for this study. 
TABLE 4. RESULTS OF UPSET FORGING(a) OF NIOBIUM-URANIUM AND NIOBIUM-URANIUM-ZIRCONIUM ALLOYS

\begin{tabular}{|c|c|c|}
\hline $\begin{array}{c}\text { Alloy Composition } \\
\text { (Balance Niobium), } \\
\text { w/o }\end{array}$ & $\begin{array}{c}\text { Fabrication } \\
\text { Temperature, } \\
\text { F } \\
\end{array}$ & Remarks \\
\hline $30 \mathrm{U}$ & 3000 & Slab fractured; severe surface cracks \\
\hline $30 \mathrm{U}-10 \mathrm{Zr}$ & 3000 & Slab fractured; severe surface cracks \\
\hline $40 \mathrm{U}$ & 3000 & Slab fractured \\
\hline $40 \mathrm{U}-10 \mathrm{Zr}$ & 3000 & Slab fractured \\
\hline $30 \mathrm{U}$ & 2800 & $\begin{array}{l}\text { Surface cracks; slab fractured into five } \\
\text { pieces }\end{array}$ \\
\hline $30 \mathrm{U}-10 \mathrm{Zr}$ & 2800 & $\begin{array}{l}\text { Surface cracks; slab fractured into three } \\
\text { pieces }\end{array}$ \\
\hline $40 \mathrm{U}-10 \mathrm{Zr}$ & 2800 & Slab fractured into three pieces \\
\hline $40 \mathrm{U}-20 \mathrm{Zr}$ & 2800 & Slab fractured \\
\hline $30 \mathrm{U}$ & 2400 & Slab fractured; slight surface cracks \\
\hline $30 \mathrm{U}-10 \mathrm{Zr}$ & 2400 & $\begin{array}{l}\text { Slab in two pieces; material appears sound } \\
\text { otherwise }\end{array}$ \\
\hline $40 \mathrm{U}-10 \mathrm{Zr}$ & 2400 & $\begin{array}{l}\text { Slab in one piece; edge cracks; radiograph } \\
\text { shows signs of slight internal cracks }\end{array}$ \\
\hline $40 \mathrm{U}-20 \mathrm{Zr}$ & 2400 & $\begin{array}{l}\text { Slab fractured into two pieces; material } \\
\text { appears to be sound otherwise }\end{array}$ \\
\hline
\end{tabular}

(a) Ingot was encased in evacuated molybdenum cans.

$\underline{\text { Rod Rolling }}$

Rod-rolling techniques were adopted for further studies of the effects of temperature on the fabrication characteristics of the niobium-uranium and niobium-uraniumzirconium alloys. Rod rolling offers a combination of advantages not obtainable by other methods available; it permits controlled reductions, radial restraint of ingots( 2 ), and the use of small cast ingots. Small right circular cylinders $1 / 2$ in. in diameter and 3 in. long were prepared by tungsten-electrode arc-melting techniques. Charges weighing 125 to $150 \mathrm{~g}$ were melted six times to insure homogeneity and were then cast into a rightcylinder water-cooled copper mold. These castings were prepared from niobium melting stock which contained $94 \mathrm{ppm}$ oxygen. The castings were given a homogenization anneal at $2300 \mathrm{~F}$ for $4 \mathrm{hr}$ and furnace cooled, and then they were inserted into molybdenum cans. These can assemblies, as shown in Figure 1, were reduced from a diameter of 1 in. to $3 / 8$ in. in rod rolls.

The temperature of fabrication and the composition of the alloys which were rod rolled are shown in Table 5. Observations concerning the conditions of the alloy specimens after fabrication were made by radiographing the can assembly. Figure 2 shows radiographs of alloys rolled at $2800 \mathrm{~F}$. As can be observed, the niobium-10 w/o uranium alloy is sound, the niobium-20 w/o uranium alloy shows evidence of cracking near one end, while the niobium $-30 \mathrm{w} / 0$ uranium and niobium $-30 \mathrm{w} / 0 \mathrm{uranium}-10$ and $-20 \mathrm{w} / 0$ 


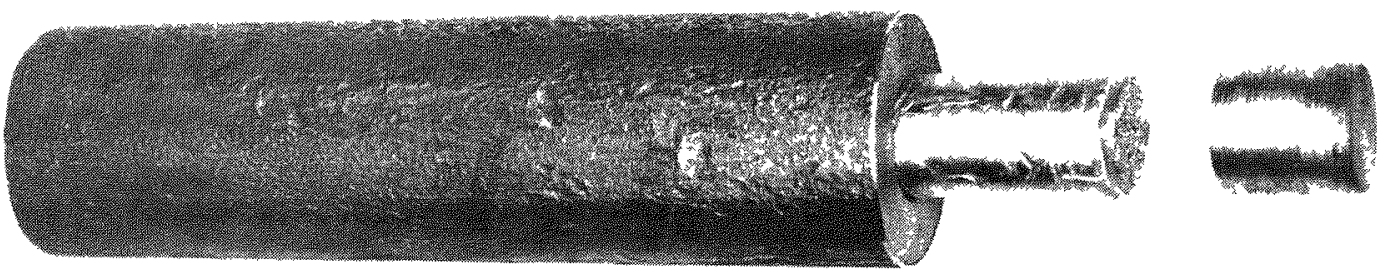

FIGURE 1. CAN ASSEMBLY

The end cap and outer tube are made of molybdenum. A portion of the casting can be seen protruding from the can. The plug shown on the extreme right is welded into place in an inert-atmosphere dry box.

TABLE 5. FABRICATION OF 1-IN. -DIAMETER CYLINDERS CONTAINING NIOBIUM-URANIUM AND NIOBIUMURANIUM-ZIRCONIUM ALLOYS

\begin{tabular}{ccc}
\hline $\begin{array}{c}\text { Alloy Composition } \\
\text { (Balance Niobium), } \\
\text { w/o }\end{array}$ & $\begin{array}{c}\text { Temperature, } \\
\text { F }\end{array}$ & Remarks \\
\hline $10 \mathrm{U}$ & 2800 & $\begin{array}{c}\text { Sound rod } \\
\text { Ditto }\end{array}$ \\
$20 \mathrm{U}$ & & Fractured \\
$30 \mathrm{U}$ & & $\begin{array}{c}\text { Ditto } \\
\text { Ditto }\end{array}$ \\
$30 \mathrm{U}-10 \mathrm{Zr}$ & & Fractured \\
$30 \mathrm{U}-20 \mathrm{Zr}$ & & $\begin{array}{c}\text { Ditto } \\
\text { Ditto }\end{array}$ \\
$30 \mathrm{U}$ & 2400 & Sound rod \\
$30 \mathrm{U}-10 \mathrm{Zr}$ & & Ditto \\
$30 \mathrm{U}-20 \mathrm{Zr}$ & & Fractured \\
$10 \mathrm{U}$ & 2100 & Ditto \\
$20 \mathrm{U}$ & & Ditto \\
$30 \mathrm{U}$ & & \\
$30 \mathrm{U}-10 \mathrm{Zr}$ & & $\mathrm{Zr}$
\end{tabular}


Niobium - 10 w/o uronium

Niobium - 20 w/o uranium

Niobium -30 w/o uronium

Niobium -30 w/o uranium - 10 w/o zirconium

Niobium -30 w/o uranium -20 w/o zirconium

FIGURE 2. RADIOGRAPH OF NIOBIUM-URANIUM ALLOYS

ROD ROLLED AT $2800 \mathrm{~F}$ 
zirconium alloys are badly fractured. Examination of the fractured areas of these alloys showed areas which appeared to have been molten. Microstructural examination revealed severe coring in alloys containing $30 \mathrm{w} / \mathrm{o}$ or more uranium. On the basis of the niobium-uranium phase diagram (Figure 3$)(3)$ and the shape of the liquidus and solidus curves, it would be expected that coring would be observed in alloys containing more than about $20 \mathrm{w} / 0$ uranium. Furthermore, if coring-type segregation is suffimciently severe, local areas could be molten at the higher $(2800$ to $3000 \mathrm{~F})$ fabrication temperatures employed. At $3000 \mathrm{~F}$, segregated areas containing $50 \mathrm{w} / 0$ uranium would be molten and areas containing $70 \mathrm{w} / 0$ uranium would cause localized melting at $2800 \mathrm{~F}$. Since the lower-melting constituents are segregated at grain boundaries, the alloys are effectively hot short during fabrication at the higher temperatures employed in these studies. If this analysis of the fabrication problems is correct, then fabricability should be improved by lowering the temperature of working. Such improvement was indicated in material which was upset forged, as seen previously in Table 4.

In an effort to further determine if the above analysis was correct, several alloys were fabricated at both 2400 and $2100 \mathrm{~F}$. Although the results of rolling the niobium -30 w/o uranium alloy at $2400 \mathrm{~F}$ were generally bette $r$ than those obtained by working at $2800 \mathrm{~F}$, the results were still unacceptable. Figure 4 shows a radiograph of the can as sembly containing the niobium $-30 \mathrm{w} / 0$ uranium alloy after fabrication at $2400 \mathrm{~F}$. While the cracks appear larger, the number of cracks is less than obtained at $2800 \mathrm{~F}$. At $2100 \mathrm{~F}$, material was produced which contained still fewer cracks than did material fabricated at the higher temperatures. Despite the improvement, however, fabricability was still poor.

It appears that segregation is the main deterrent to successful fabrication of niobium-uranium alloys containing more than $30 \mathrm{w} / \mathrm{o}$ uranium. The high strength of these alloys makes high temperatures a requisite for fabrication while coring limits the fabrication temperatures which may be employed without rendering the alloy hot short. Obviously, it would be desirable to produce a more homogeneous alloy for fabrication. However, diffusion rates in the niobium-uranium system are quite low until temperatures close to the melting point are achieved. As reported in a later section on phase studies, attempts to homogenize niobium-uranium alloys by annealing at temperatures ranging from 1200 to $1600 \mathrm{C}$ for $8 \mathrm{hr}$ were unsuccessful. Consequently, attempts to improve alloy homogeneity were restricted to attempts to improve the cast product by means of consumable-electrode skull casting.

\section{CONSUMABLE-ELECTRODE SKULL-CASTING STUDIES}

With conventional consumable-electrode arc melting segregation has been observed both in the form of microsegregation, resulting from the wide liquidus-solidus temperature range (Figure 3) for the high-uranium alloys, and as macrosegregation in the form

of banding. This banding appears to result from the density differences between niobium and uranium as well as wander and fluctuation of the arc during conventional arc melting. (4)

In an attempt to produce niobium alloys containing $30 \mathrm{w} / 0$ or more uranium with structures amenable to fabrication, skull-melting techniques were investigated. Six ingots with compositions varying from pure niobium to niobium-50 w/o uranium were 


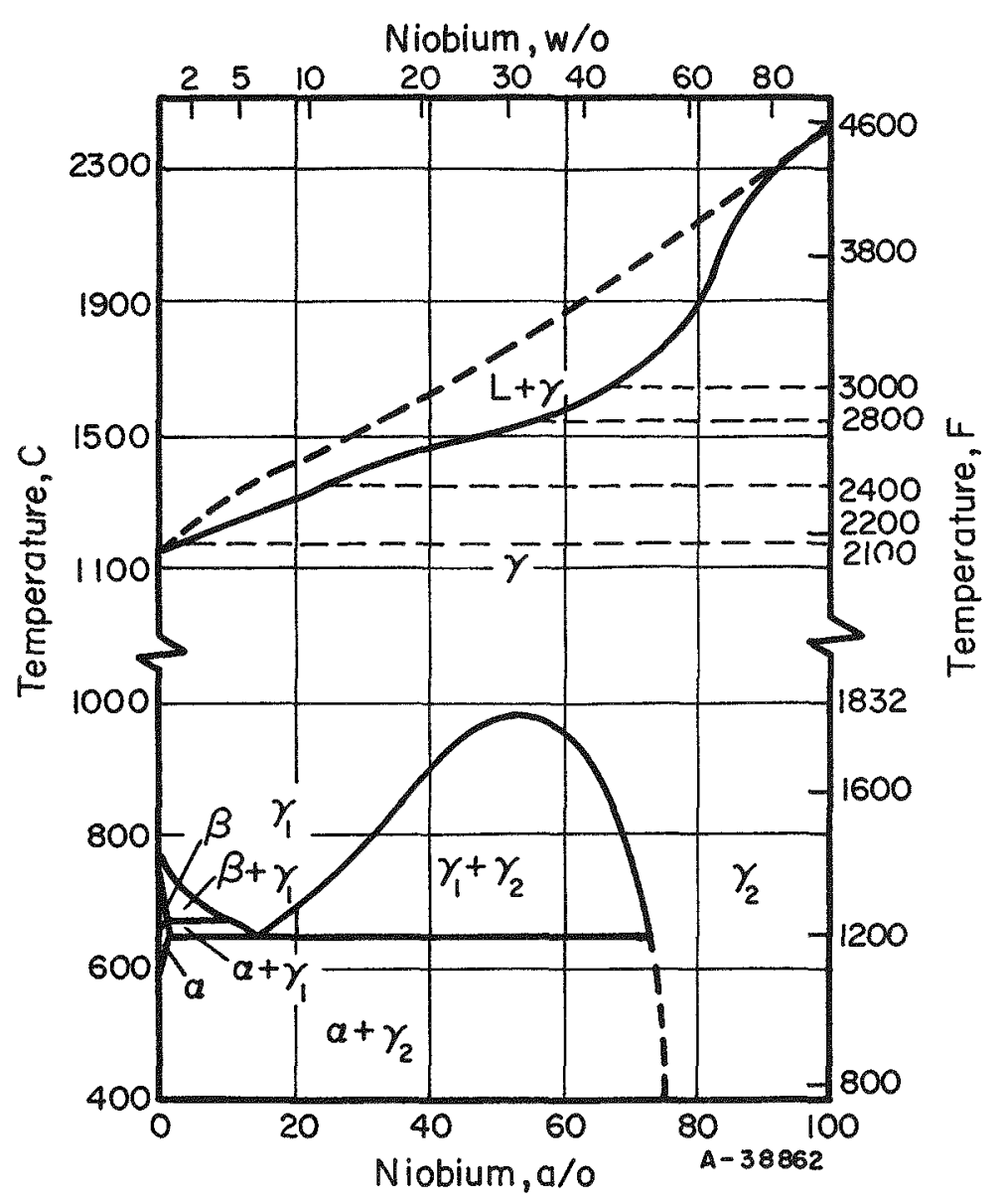

FIGURE 3. NIOBIUM-URANIUM PHASE DIAGRAM

Dashed lines show temperature of fabrication and points where segregation could cause localized melting. (3) 


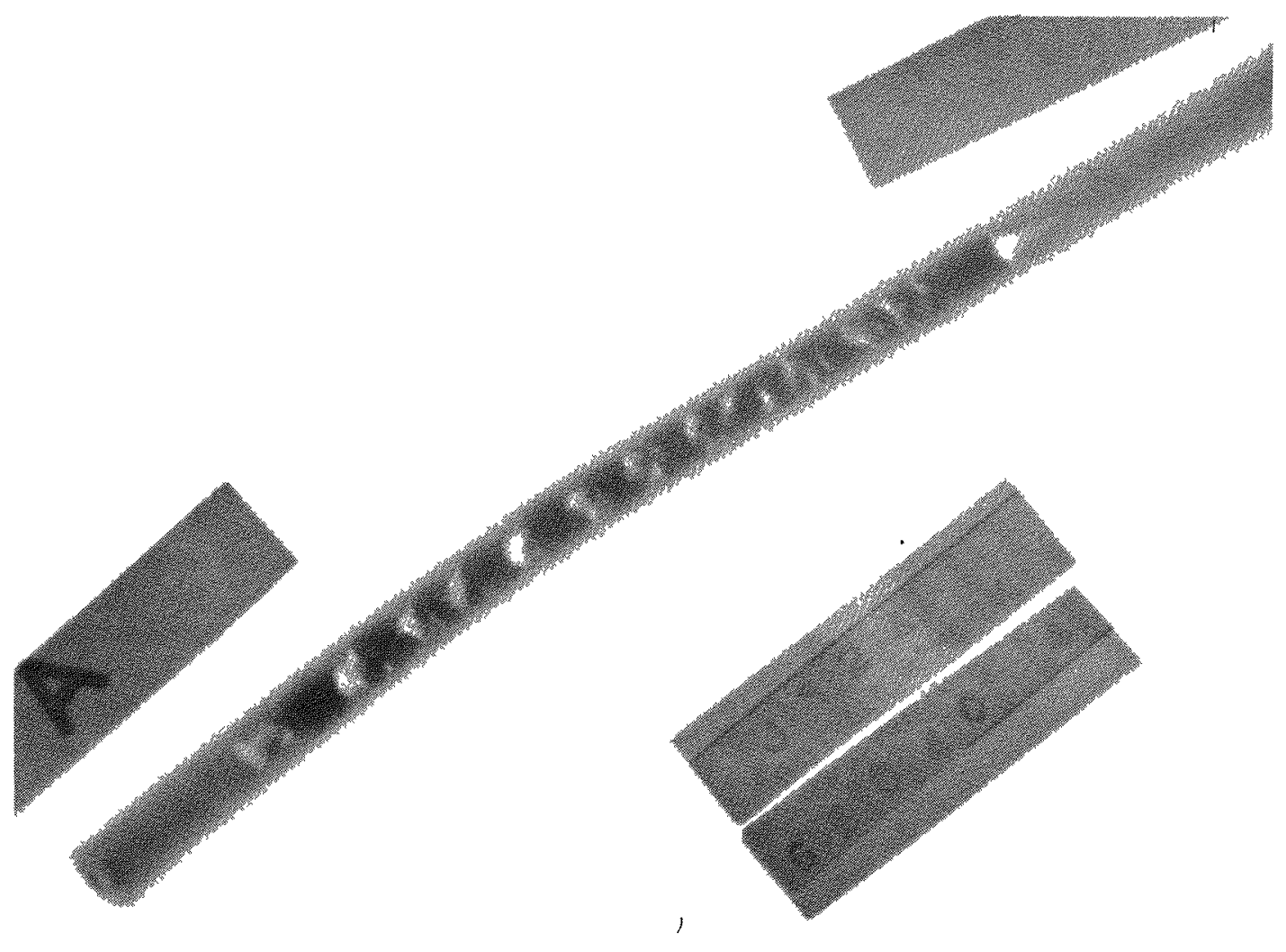

FIGURE 4. RADIOGRAPH OF NIOBIUM-30 w/O URANIUM ALLOY ROD ROLLED AT $2400 \mathrm{~F}$ 
prepared by means of consumable-electrode melting into a skull prior to pouring into a copper mold. Although microsegregation in niobium-uranium ingots with greater than $20 \mathrm{w} / 0$ uranium appears to be inherent in a cast product, it was felt that the macrosegregation ox banding might be eliminated by skull-melting procedures since arc-current fluctuations while the metal is solidifying, as in conventional cold-mold arc melting, would not be present. In addition, past experience with skull melting and casting of other alloys has revealed that the grain size of the cast product is reduced as compared with that observed in conventional cold-mold arc-melted material. It was anticipated that this reduced grain size, if obtained, would further facilitate subsequent fabrication.

\section{Melting Studies}

The starting materials consisted of a center-cut biscuit uranium having a nominal analysis of $30 \mathrm{ppm}$ oxygen and $2 \mathrm{ppm}$ hydrogen and niobium sintered bar (Table 3 ).

In order to build up a skull of sufficient height and thickness to allow for adequate molten metal to fill the mold, a lower grade of niobium (containing approximately $500 \mathrm{ppm}$ oxygen) was used. Three electrodes of approximately $8 \mathrm{lb}$ each of this unalloyed niobium were consumably melted into the water-cooled copper skull under a vacuum. After the last of these melts, an experimental ingot was poured to obtain a cavity in the skull of sufficient depth to allow for adequate molten metal to fill the mold. (Some metal will remain as solid in the skull due to heat losses to the water-cooled crucible.) This mold (Figure 5) consisted of three stepwise sections having the dimensions 3 by 4 by 1 in., 3 by 2 by $1 / 2$ in., and 3 by 2 by $1 / 4$ in. The mold cavity was adequately filled and a cursory examination of the resultant ingot revealed a very good surface.

The electrodes prepared for consumable-electrode arc melting into the skull prepared above consisted of 3/4-in.-square niobium bar with appropriately weighed uranium strips welded to opposite sides of the electrode. Uranium strips of the proper dimensions were pickled and fusion welded to the niobium in an inert atmosphere. Two electrodes of this type were welded together edgewise so as to give a final electrode with a cross section of approximately $1-1 / 2$ by $3 / 4$ (plus appropriate uranium width) in. Each electrode then contained approximately 100 per cent overcharge of material required to fill the mold. The electrode configuration can be seen in Figures 6 and 7 which illustrate the skull-melting setup.

All ingots were melted under vacuum utilizing from 3000 to 3500 -amp arc current, and were cast into the water-cooled copper mold. The unalloyed niobium was melted first followed by melts of increasing uranium content. A tabulation of the cast ingot sizes can be found in Table 6.

Recovery (i.e., weight of ingot/weight of electrode) was adequate in all cases except for the two unalloyed niobium ingots. As referenced in Table 6, two unalloyed niobium ingots were poured. The recovery for each of these was only 12 per cent compared with a recovery of greater than 50 per cent with all alloyed ingots. The cause of this poor recovery is not known. Factors which can influence recovery include: skull- and electrode-alloy melting points, the starting weight of the skull, and the position and the fit of the skull in the copper crucible.

As can be seen from the chemical analysis of the resultant ingots (Table 7) the uranium content in all alloys was lower than that desired. It appears that some remelting 


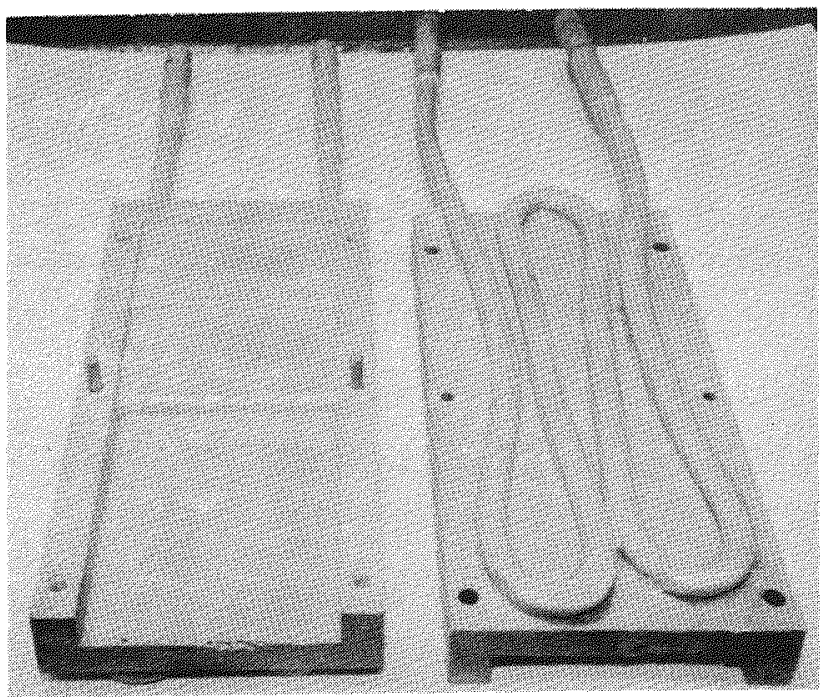

FIGURE 5. WATER-COOLED COPPER STEP MOLD Mold size, top to bottom: 3 by $1 / 4$ by 2 in. 3 by $1 / 2$ by 2 in. 3 by 1 by 4 in.

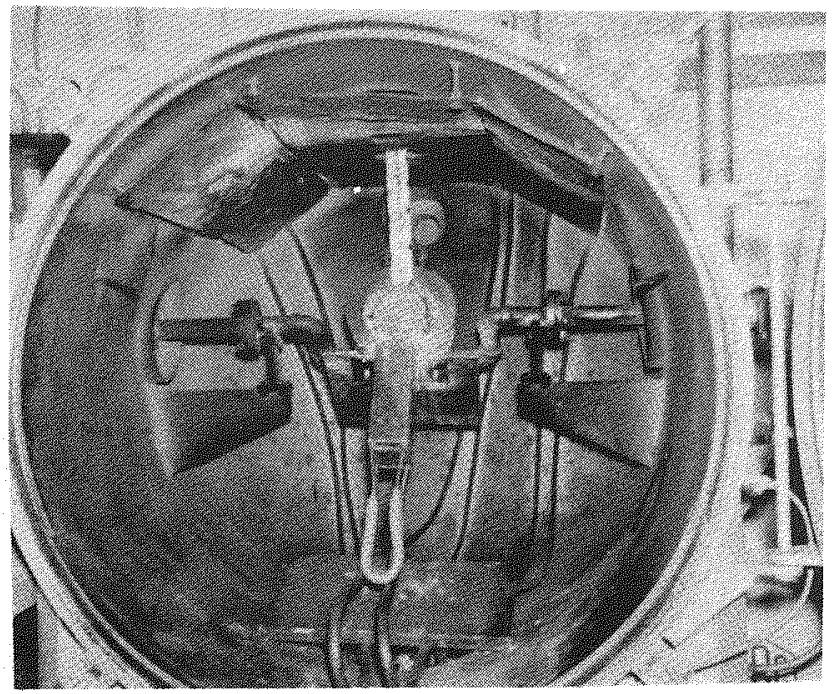

FIGURE 6. SKULL-MELTING-FURNACE SETUP SHOWING VACUUM CHAMBER

Electrode is in position with crucible tipped for pouring.

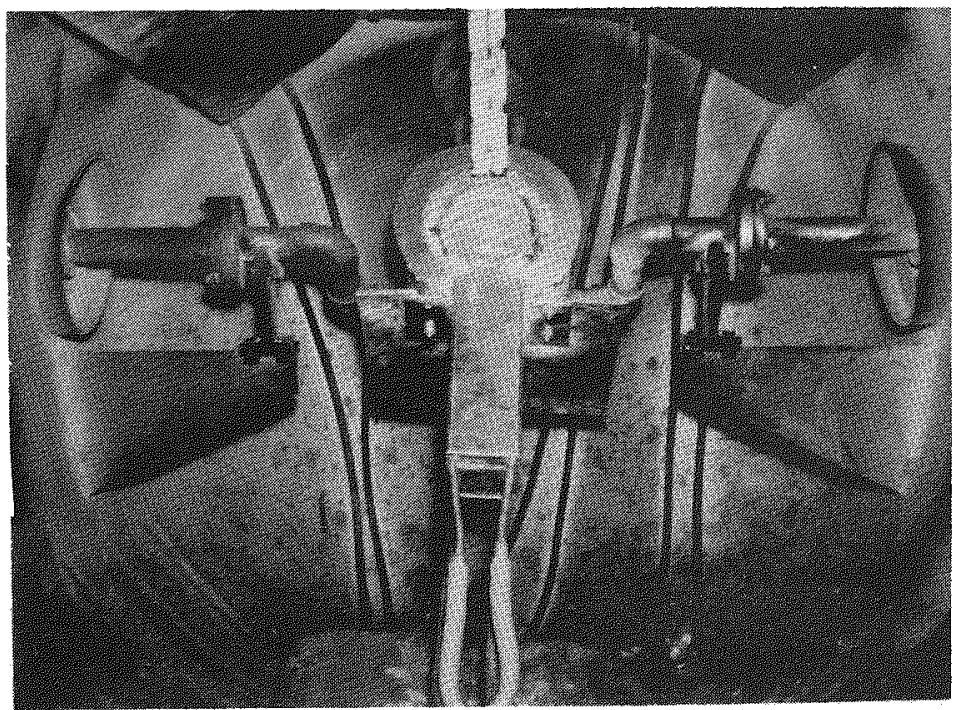

FIGURE 7. VIEW OF FURNACE INTERIOR SHOWING SKULL BUILDUP IN CRUCIBLE 
TABLE 6. SIZE OF EACH NIOBIUM-URANIUM INGOT CAST UTILIZING CONSUMABLE-ELECTRODE SKULLMELTING TECHNIQUES

\begin{tabular}{|c|c|c|}
\hline Ingot & $\begin{array}{c}\text { Nominal Composition } \\
\text { (Balance Niobium) } \\
\text { w/o }\end{array}$ & Ingot Size(a) \\
\hline $\mathrm{Nb}-\mathrm{X}$ & Unalloyed $\mathrm{Nb}(\mathrm{b})$ & $\begin{array}{l}3 \text { by } 1 \text { by } 1-1 / 4 \text { in. } \\
3 \text { by } 1 \text { by } 1-1 / 4 \text { in. }\end{array}$ \\
\hline A & $10 \mathrm{U}$ & $\begin{array}{l}3 \text { by } 1 \text { by } 4 \text { in. } \\
3 \text { by } 1 / 2 \text { by } 2 \text { in. } \\
3 \text { by } 1 / 4 \text { by } 2 \text { in. }\end{array}$ \\
\hline B & $20 \mathrm{U}$ & $\begin{array}{l}3 \text { by } 1 \text { by } 4 \text { in. } \\
3 \text { by } 1 / 2 \text { by } 2 \text { in. }\end{array}$ \\
\hline C & $30 \mathrm{U}$ & $\begin{array}{l}3 \text { by } 1 \text { by } 4 \text { in. } \\
3 \text { by } 1 / 2 \text { by } 2 \text { in. } \\
3 \text { by } 1 / 4 \text { by } 2 \text { in. }\end{array}$ \\
\hline $\mathrm{D}$ & $40 U^{(b)}$ & 3 by 1 by 4 in. \\
\hline $\mathrm{E}$ & $50 \mathrm{U}$ & $\begin{array}{l}3 \text { by } 1 \text { by } 4 \text { in. } \\
3 \text { by } 1 / 2 \text { by } 2 \text { in. } \\
3 \text { by } 1 / 4 \text { by } 2 \text { in. }\end{array}$ \\
\hline
\end{tabular}

(a) All slabs of the same composition were cast in the same ingot utilizing a mold of stepwise configuration with the exception of unalloyed niobium slabs which were cast independently.

(b) Attempted to cast only larger section ( 3 by 1 by 4 in.) of mold.

TABLE 7. ANALYSIS OF SKULL-MELTED NIOBIUMURANIUM INGOTS

\begin{tabular}{ccccc}
\hline Ingot & \begin{tabular}{c} 
Uranium Content, w/o \\
\cline { 2 - 5 } Nominal
\end{tabular} & $\begin{array}{c}\text { Analyzed } \\
\text { ppm }\end{array}$ & $\begin{array}{c}\text { Oxygen, } \\
\text { ppm }\end{array}$ \\
\hline A & 10 & 4.38 & 3 & 160 \\
B & 20 & 14.3 & -- & -- \\
C & 30 & 25.0 & -- & -- \\
D & 40 & 34.6 & -- & -- \\
E & 50 & 46.7 & 2 & 115 \\
\hline
\end{tabular}


of the residual skull, which was lower alloy content, occurred in each case, thereby lowering the uranium content below that desired. This occurrence is the reverse of that observed in melting the two unalloyed niobium charges where a great percentage of the charge material was not recovered but froze onto the existing skull. The decreasing melting point of niobium with increasing uranium content may, in part, explain this behavior. In addition, the skull was removed after each melt to facilitate positioning of the next electrode to be melted. Due to slight variations in the contour of the outside surface of the skull, the heat-transfer coefficient across the skull-crucible interface could be altered sufficiently to have a significant effect on the rate of cooling in the skull.

The oxygen pickup upon melting appears to be very small as indicated in Table 7. Analyses were made on one of the first ingots cast as well as the last ingot cast with the resultant analyses in the same range. Oxygen contamination from the niobium skull was minor as was expected.

Ingots containing 34.6 and $46.7 \mathrm{w} / \mathrm{o}$ uranium both cracked upon solidification. The fracture interface shows an area of very porous material, most probably a result of shrinkage. (See Figure 8). These alloys apparently could not withstand the thermal shock imparted by chilling on the water-cooled copper mold.

A photograph of all of the ingots cast is shown in Figure 9. The $\mathrm{Nb}-\mathrm{X}$ ingot was cast during the skull buildup and was subsequently used as a mold plug for casting the single-mold section of unalloyed niobium and niobium-40 w/o uranium ingots.

The microstructures shown in Figure 10 of selected compositions appear very similar to those cast by the conventional cold-mold consumable-electrode arc-melting technique. (1) Segregation on a microscale is present, the dark dendrites being rich in uranium.

Radiographs of the 3 by 1 by 4 -in. section of the as-cast ingots (see Figure 11) revealed quite a bit of shrinkage porosity. However, there is no evidence of macrosegregation or banding. For purposes of comparison, Figure 12, a radiograph, shows a banding in a niobium $-30 \mathrm{w} / 0$ uranium ingot cast by the conventional cold-mold arcmelting technique.

Although further development of skull-melting procedures for the production of sound niobium-uranium alloys is required, it has been shown that macrosegregation can be eliminated by skull melting and casting. Microsegregation, however, is not eliminated by these techniques.

\section{FABRICATION STUDIES OF SKULL-CAST ALLOYS}

Flat rolling was the only fabrication method employed for the skull-cast slabs. The 1/2- and 1/4-in. -thick slabs were utilized in this study.

Initially, the 1/4-in.-thick slabs were rolled in air at $1000 \mathrm{~F}$. Both the niobium25.0 and $-46.7 \mathrm{w} / 0$ uranium alloy showed edge cracking after very slight reductions in thickness and the rolling temperature was raised to $1850 \mathrm{~F}$. At this temperature, the 


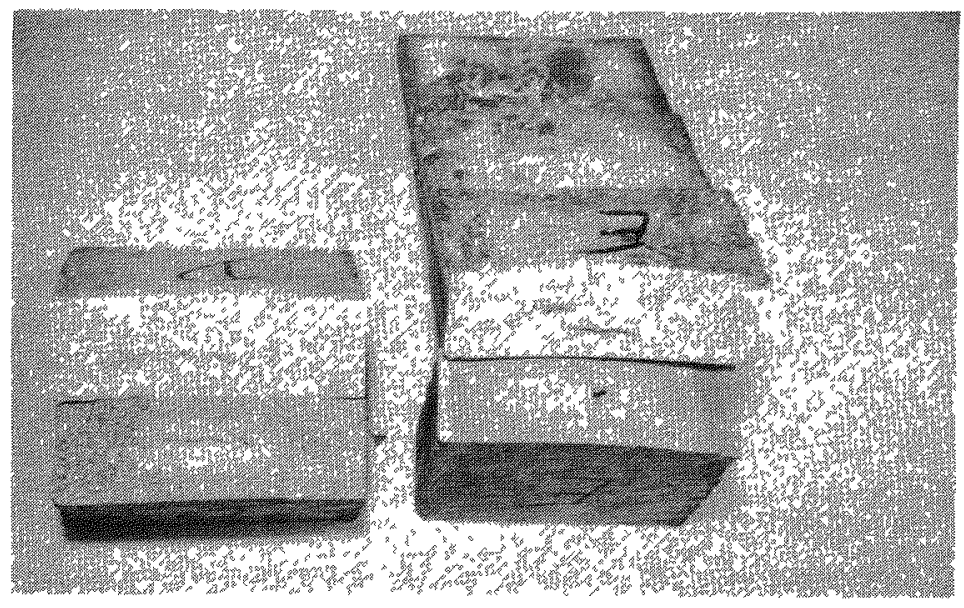

FIGURE 8. FRACTURED SURF ACES OF INGOTS CONT AINING 34.6 W/O URANIUM (INGOT D) AND 46.7 w/o URANIUM (INGOT E)

The fractured interfaces show areas of porous material which probably is due to shrinkage.

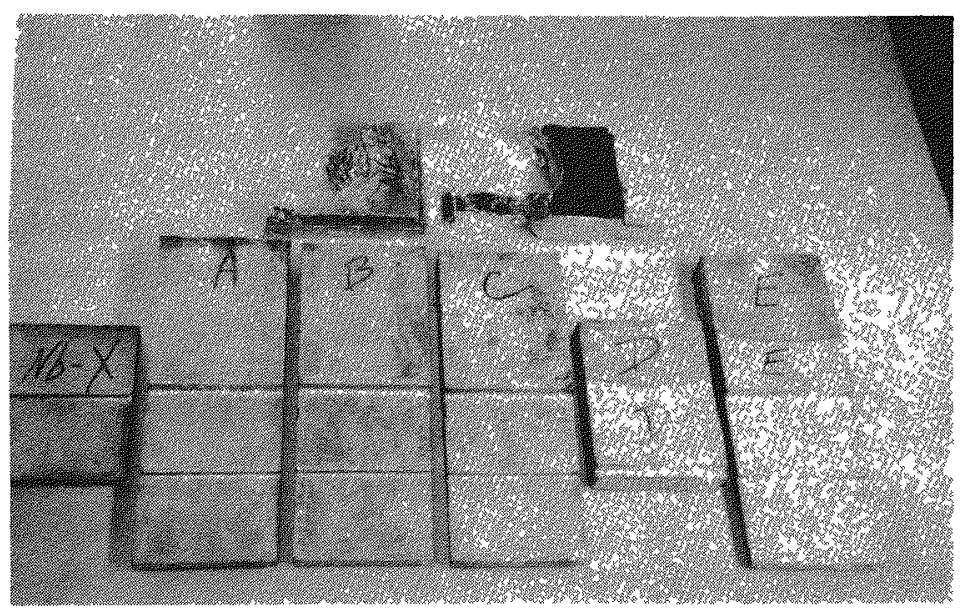

FIGURE 9. SKULL-MELTED NIOBIUM-URANIUM INGOTS

Identification:
$\mathrm{Nb}-\mathrm{X}$ - unalloyed niobium
C - niobium-25.0 w/o uranium
A - niobium $-4.38 \mathrm{w} / \mathrm{o}$ uranium
D - niobium-34.6 w/o uranium
B - niobium-14.3 w/o uranium
E - niobium-46.7 w/o uranium 


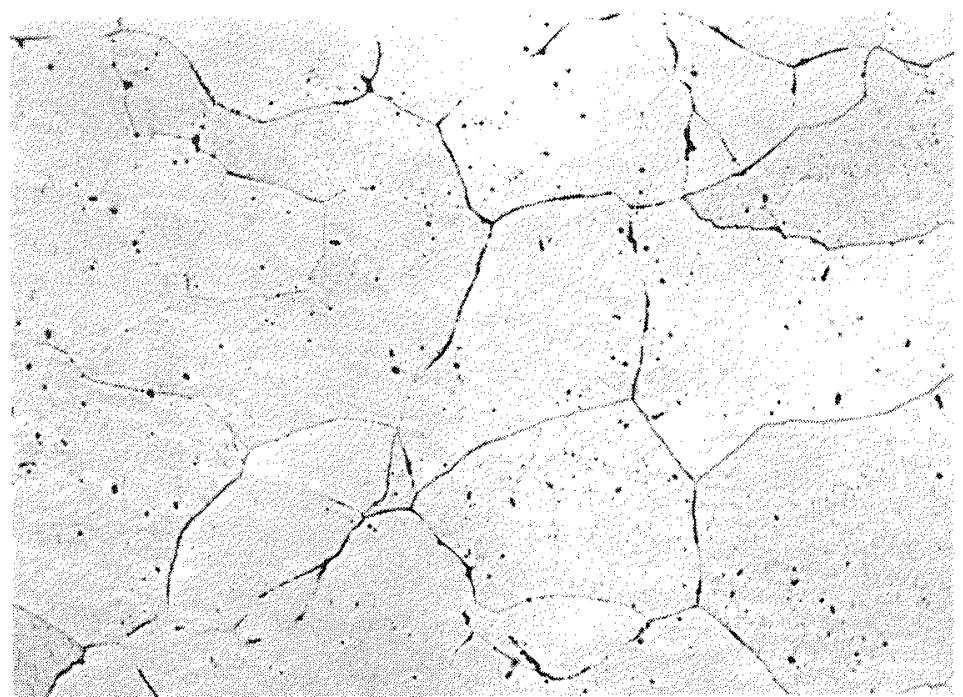

$100 \mathrm{x}$

RM18355

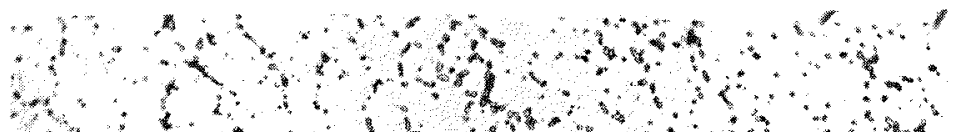

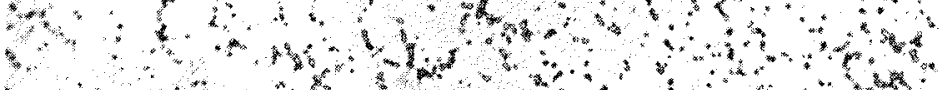

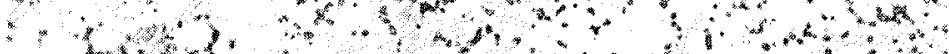
$\left.x^{2}+4,30,1\right\}$

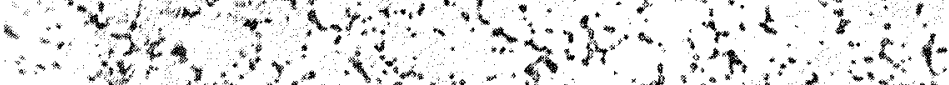

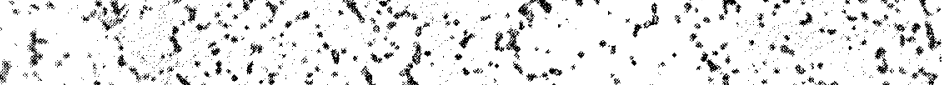

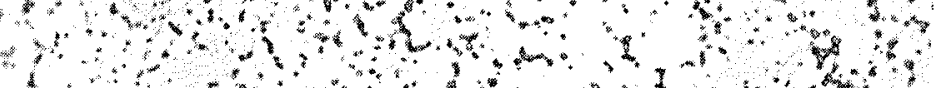

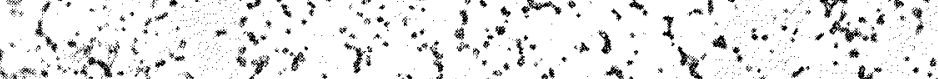

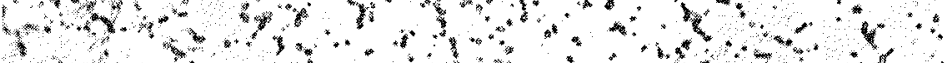

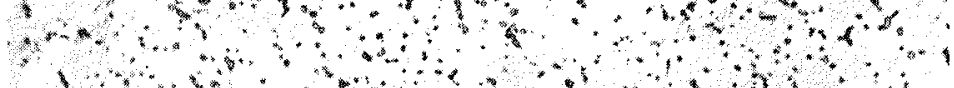

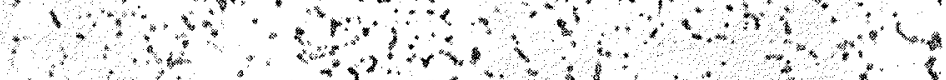

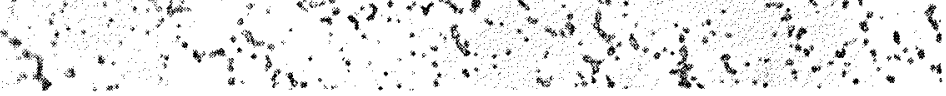
$100 \mathrm{X}$

RM18359

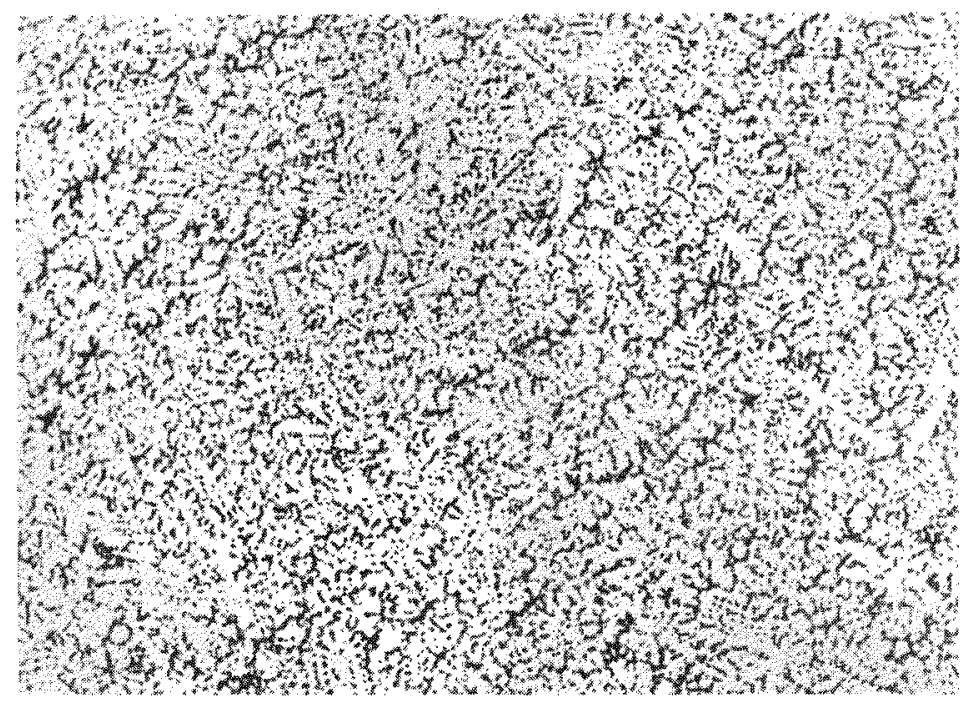

a. Niobium $-4.38 \mathrm{w} / \mathrm{o}$ Uranium

Slight grain-boundary segregation is evident.

b. Niobium-25.0 w/o Uranium

Note dendritic, cored structure.

c. Niobium $-46.7 \mathrm{w} / \mathrm{o}$ Uranium

Two-phase structure is shown.

FIGURE 10. MICROSTRUCTURES OF SKULLMELTED NIOBIUM-URANIUM ALLOYS 


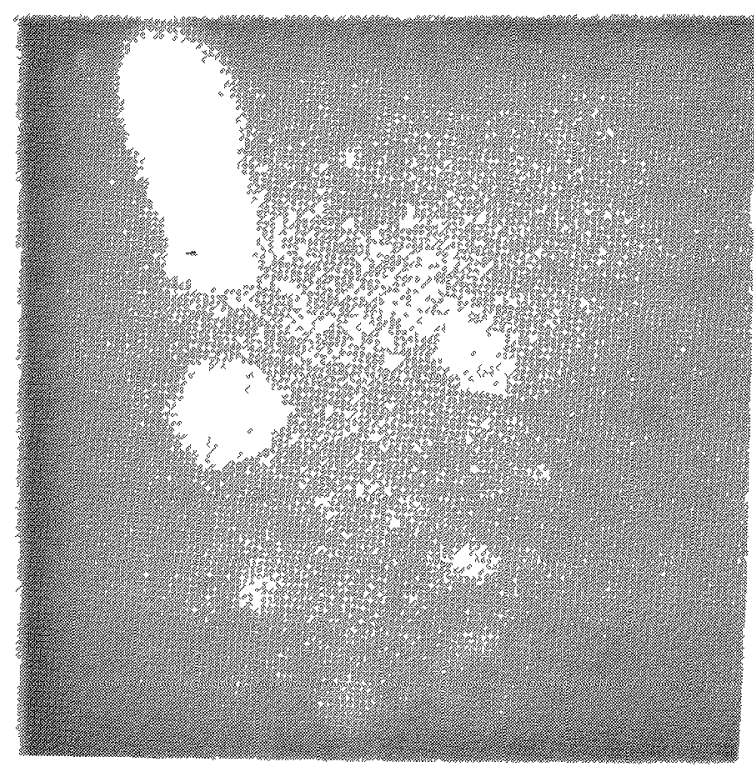

a. Niobium-4.38 w/o Uranium, Ingot $A$

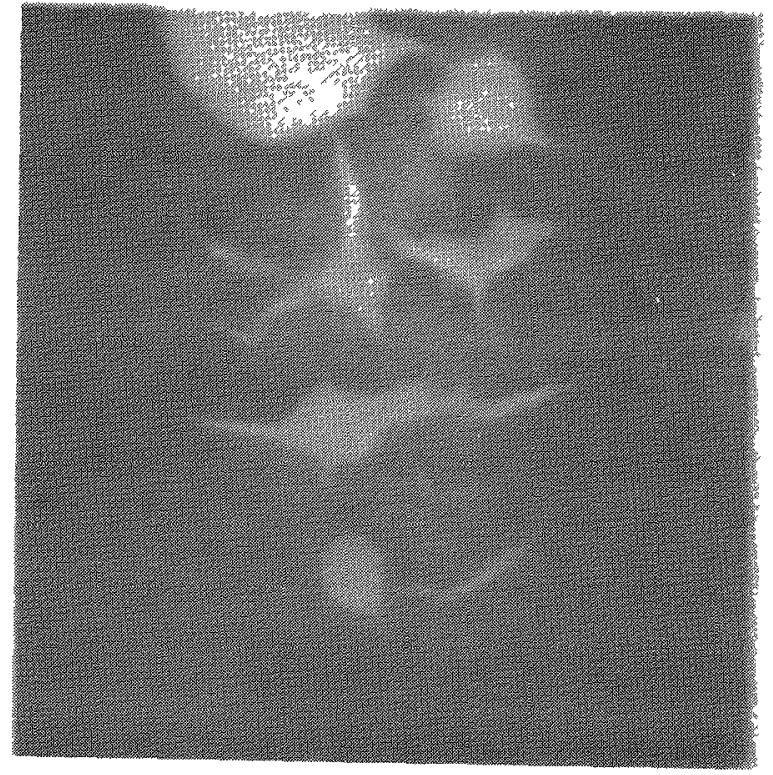

b. Niobium-25.0 w/o Uranium, Ingot $C$

FIGURE 11. RADIOGRAPHS OF NIOBIUM-URANIUM INGOTS

Extensive shrinkage is evident. No macrosegregation or banding is visible. 


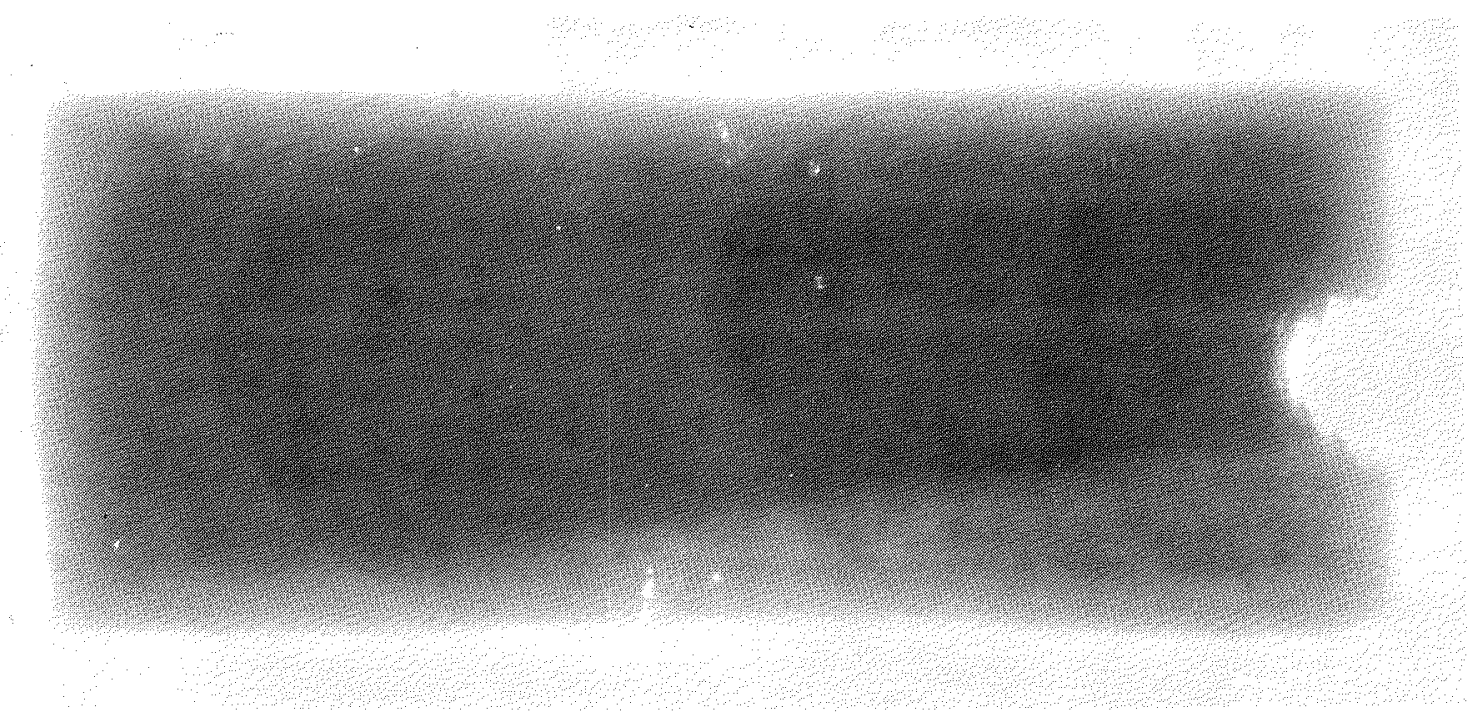

FIGURE 12. RADIOGRAPH SHOWING MACROSEGREGATION OR BANDING IN A NIOBIUM-30 w/o URANIUM ALLOY CAST BY THE CONVENTIONAL CONSUMABLE-ELECTRODE ARC-MELTING TECHNIQUE 
niobium-25.0 w/o uranium alloy was reduced with some edge and surface cracking but fabrication of the niobium $-46.7 \mathrm{w} / 0$ uranium alloy was unsuccessful. These results are summarized in Table 8. Figure 13 shows macrographs of the fabricated sheet. The fabricability of the 4.38 and $14.3 \mathrm{w} / 0$ uranium alloys produced by skull casting appears to be better than that experienced with consumable-electrode arc castings. This was the first material whose cast structure could be broken down by direct rolling without initial forging. This improvement is probably due to ingot geometry since little evidence of grain refinement was noted. Fabrication of the niobium-25.0 w/o uranium alloy is at best marginal at $1850 \mathrm{~F}$, while the niobium $-46.7 \mathrm{w} / 0$ uranium alloy was not fabricable at either 1000 or $1850 \mathrm{~F}$.

TABLE 8. FABRICATION RESULTS WITH SKULL-CAST NIOBIUM-URANIUM ALLOYS

\begin{tabular}{|c|c|c|c|}
\hline $\begin{array}{c}\text { Composition } \\
\text { (Balance Niobium), } \\
\text { w/o }\end{array}$ & $\begin{array}{c}\text { Temperature, } \\
F\end{array}$ & $\begin{array}{l}\text { Reduction in } \\
\text { Thickness, per cent }\end{array}$ & Remarks \\
\hline $4.38 \mathrm{U}$ & 1000 & 80 & $\begin{array}{l}\text { Sound sheet, slight edge } \\
\text { cracking }\end{array}$ \\
\hline $14.3 \mathrm{U}$ & 1000 & 80 & Ditto \\
\hline \multirow[t]{2}{*}{$25.0 \mathrm{U}$} & 1000 & 10 & $\begin{array}{l}\text { Edge cracking; tempera- } \\
\text { ture raised for sub- } \\
\text { sequent fabrication }\end{array}$ \\
\hline & 1850 & $84(a)$ & $\begin{array}{l}\text { Edge and surface } \\
\text { cracking; material is } \\
\text { marginal }\end{array}$ \\
\hline \multirow[t]{2}{*}{$46.7 \mathrm{U}$} & 1000 & 1 & $\begin{array}{l}\text { Severe edge cracking; } \\
\text { temperature raised }\end{array}$ \\
\hline & 1850 & $19(a)$ & Specimen fractured \\
\hline
\end{tabular}

(a) Per cent reduction includes that obtained at $1000 \mathrm{~F}$.

A 1/2-in. -thick section of the niobium-46.7 w/o uranium alloy was sectioned into 3 by $1 / 2-i n$. pieces. These samples were encased in a molybdenum can (Figure 1) and flat rolled at $2000,2200,2400$, and $2500 \mathrm{~F}$. All of the specimens were reduced approximately 85 per cent but exhibited extensive cracking generally completely across the sheet perpendicular to the rolling direction. No successfully fabricated material was obtained.

Although improvement in the fabricability of the lower-uranium-containing alloys was observed, skull-melted material containing higher amounts of uranium (above $25 \mathrm{w} / \mathrm{o}$ ) did not appear to be any more fabricable than alloys cast by the conventional consumableelectrode arc-melting technique. 


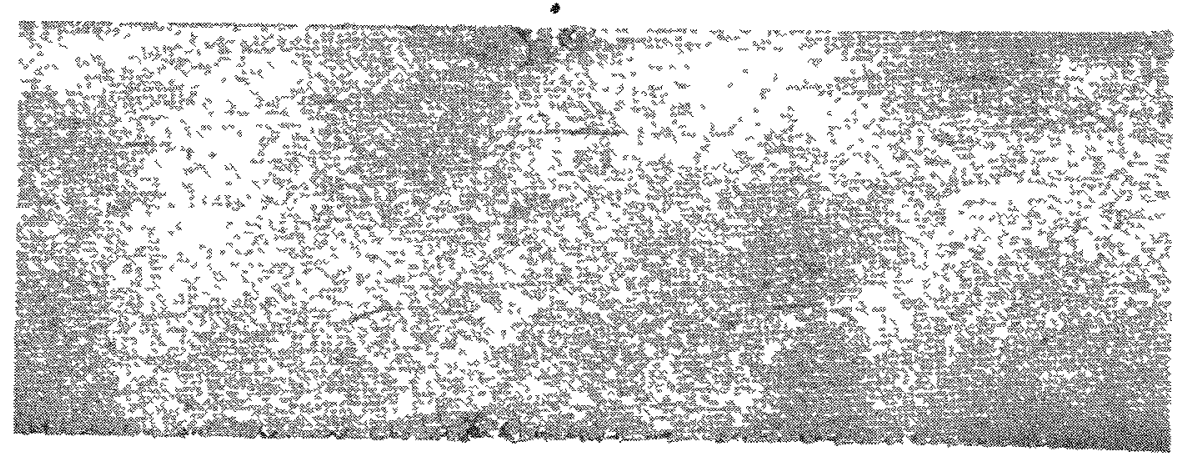

$1 \mathrm{X}$

a. Niobium-4.38 w/o Uranium Alloy Reduced 80 Per Cent by Rolling at $1000 \mathrm{~F}$

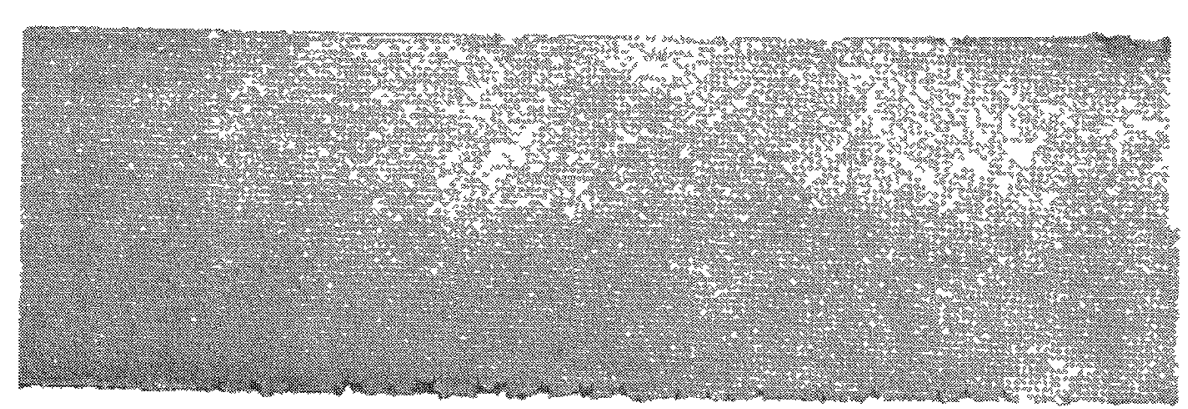

$1 \mathrm{x}$

b. Niobium-14.3 w/o Uranium Alloy Reduced 80 Per Cent by Rolling at $1000 \mathrm{~F}$
RM18037

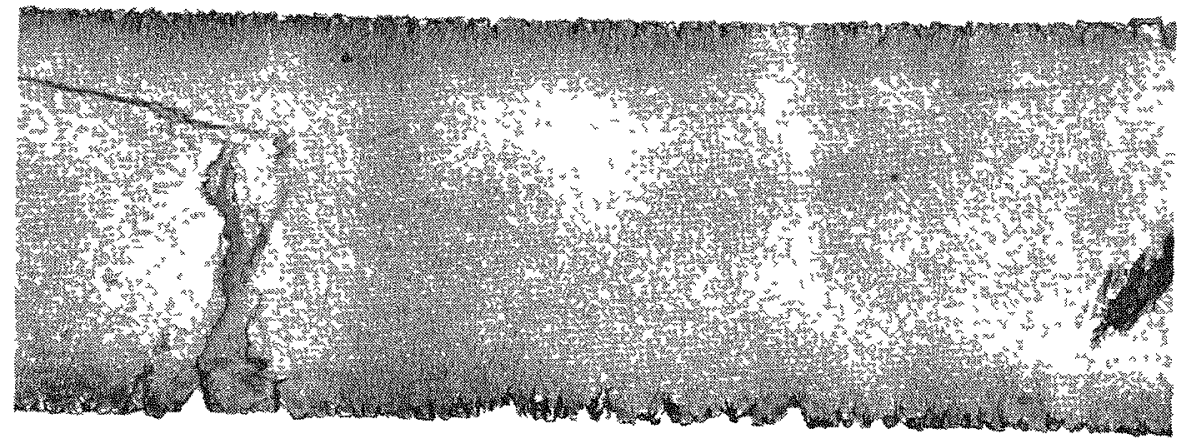

$1 X$

c. Niobium-30 w/o Uranium Alloy Reduced 84 Per Cent by Rolling at 1000 and $1850 \mathrm{~F}$
RM18038

$1 X$

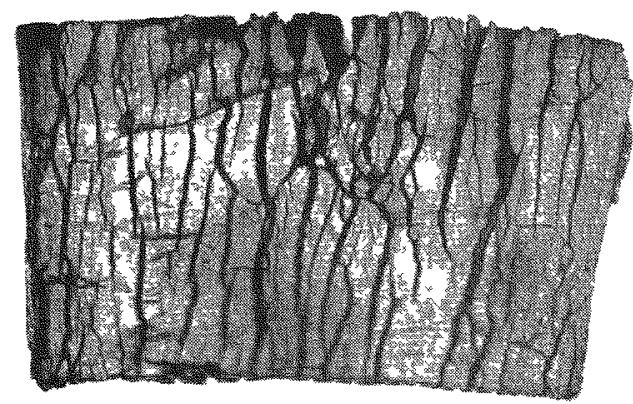

d. Niobium-46.7 w/o Uranium Alloy Specimen That Failed to Roll at $1850 \mathrm{~F}$

FIGURE 13. FLAT-ROLLED SKULL-CAST NIOBIUM-URANIUM ALLOYS 


\section{MECHANICAL-PROPERTY DETERMINATIONS}

Tensile strength and creep data for the niobium-4.38,-10,-14.3, and $-20 \mathrm{w} / \mathrm{o}$ uranium alloys were obtained at elevated temperatures. These mechanical-property data are of interest both from the viewpoint of structural design and in predicting irradiation swelling. The data presented in this section were obtained on material prepared both by skull-melting and by consumable-electrode arc-melting techniques. All specimens were given a 1 -hr vacuum stress-relief anneal at $1800 \mathrm{~F}$ prior to testing.

Elevated-Temperature Short-Time Tensile Tests

Elevated-temperature tensile tests were performed on niobium-uranium alloy sheet specimens in vacuum testing units. Stress-strain curves for temperatures below $1800 \mathrm{~F}$ were obtained with a mechanical extensometer. A deflectometer, which measured crosshead movement, was used to obtain stress-strain curves for specimens tested above $1800 \mathrm{~F}$.

Figure 14 shows plots of the tensile strengths of the niobium-uranium alloys versus temperature. The alloys shown retained their strengths well even above $2000 \mathrm{~F}$. In Figure 15, the ultimate tensile strength of the niobium-uranium alloys tested is compared with that of unalloyed niobium and niobium-2. $37 \mathrm{w} / 0$ chromium(5) a high-strength, niobium-base alloy. The niobium-uranium alloys compare quite favorably. Uranium appears to be a potent strengthener of niobium. However, from Figure 16, which is a plot of tensile strength versus uranium content, it is apparent that after the initial increase in strength further increases in strength due to increasing uranium content are relatively small. The main benefit derived from uranium content above $4 \mathrm{w} / \mathrm{o}$ is from increased fuel loading.

Tensile tests performed on the niobium-10 w/o uranium alloy material produced apparent discrepancies in strength at $1600 \mathrm{~F}$. The ultimate tensile strength of the initial alloy specimen tested was much higher than expected. Further tensile tests above $1600 \mathrm{~F}$ indicated that its strength was as high as that of the niobium-20 w/o uranium alloy. The tensile ductility of this niobium-10 w/o uranium alloy was quite low, however (1 per cent), compared with that of the niobium-20 w/o uranium alloy (10 per cent). Analyses of the wrought sheet from the three heats of the niobium-10 w/o uranium alloy being tested showed large differences in oxygen content. The oxygen content of the three heats was 680,1190 , and $3170 \mathrm{ppm}$. A plot of oxygen content versus ultimate tensile strength is shown in Figure 17 for niobium-10 w/o uranium alloys tested at $1600 \mathrm{~F}$. As can be seen, the tensile strength seems to increase linearly with increasing oxygen content while the tensile elongation drops rapidly. Since it is generally believed that the strengthening effect due to oxygen content decreases with increasing temperature, a more thorough investigation of the strength of the niobium-10 w/o uranium alloy con taining $3170 \mathrm{ppm}$ oxygen was made at temperatures up to $2200 \mathrm{~F}$. A plot of the tensile strength of the niobium-10 w/o uranium $-0.31 \mathrm{w} / \mathrm{o}$ oxygen alloy as a function of temperature is found in Figure 18. The data presented show that the niobium-10 w/o uranium $-0.31 \mathrm{w} / \mathrm{o}$ oxygen alloy is extremely brittle in the temperature range between 800 and $1500 \mathrm{~F}$. All specimens tested in the abovementioned temperature range failed while the material was still undergoing elastic deformation. These values are plotted as fracture 

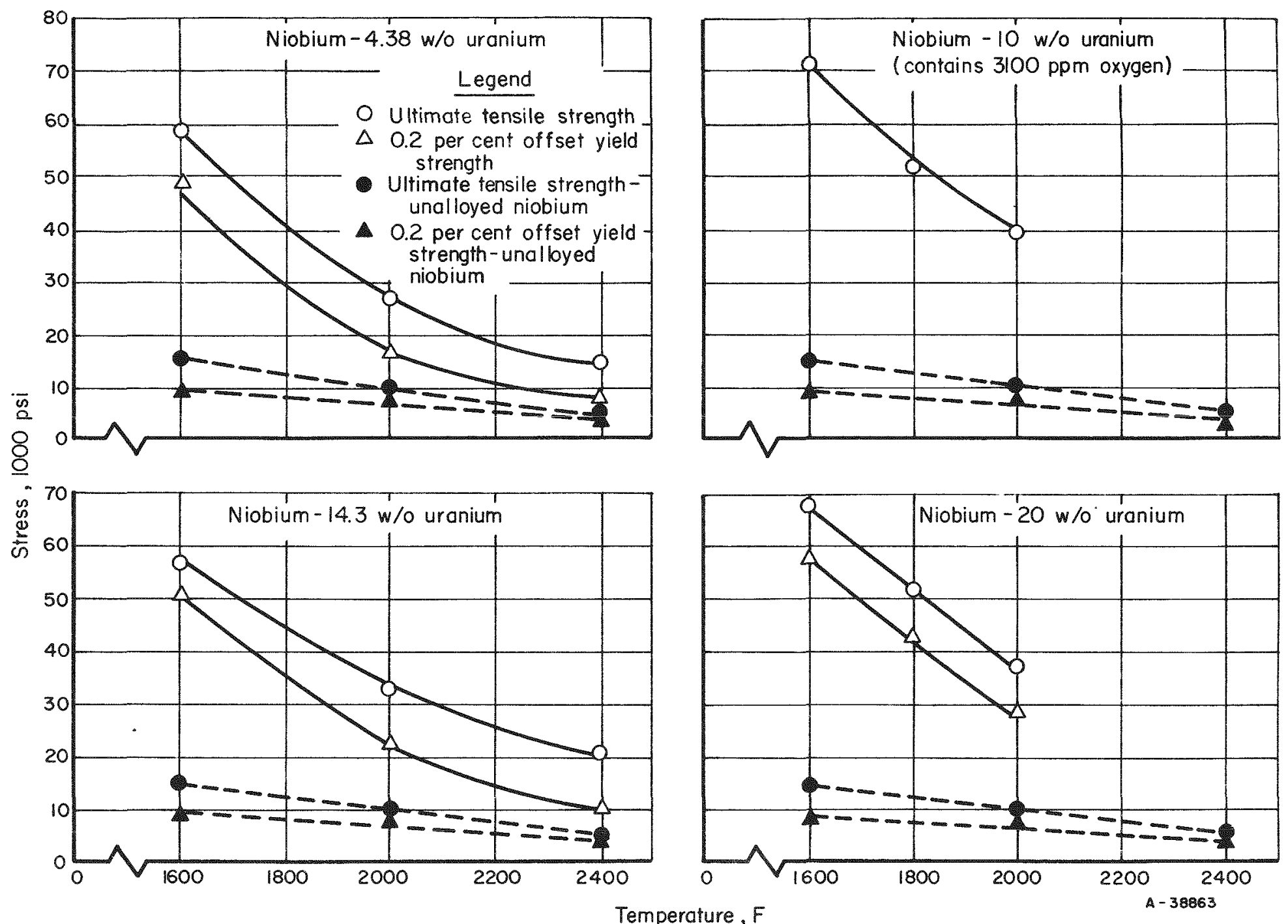


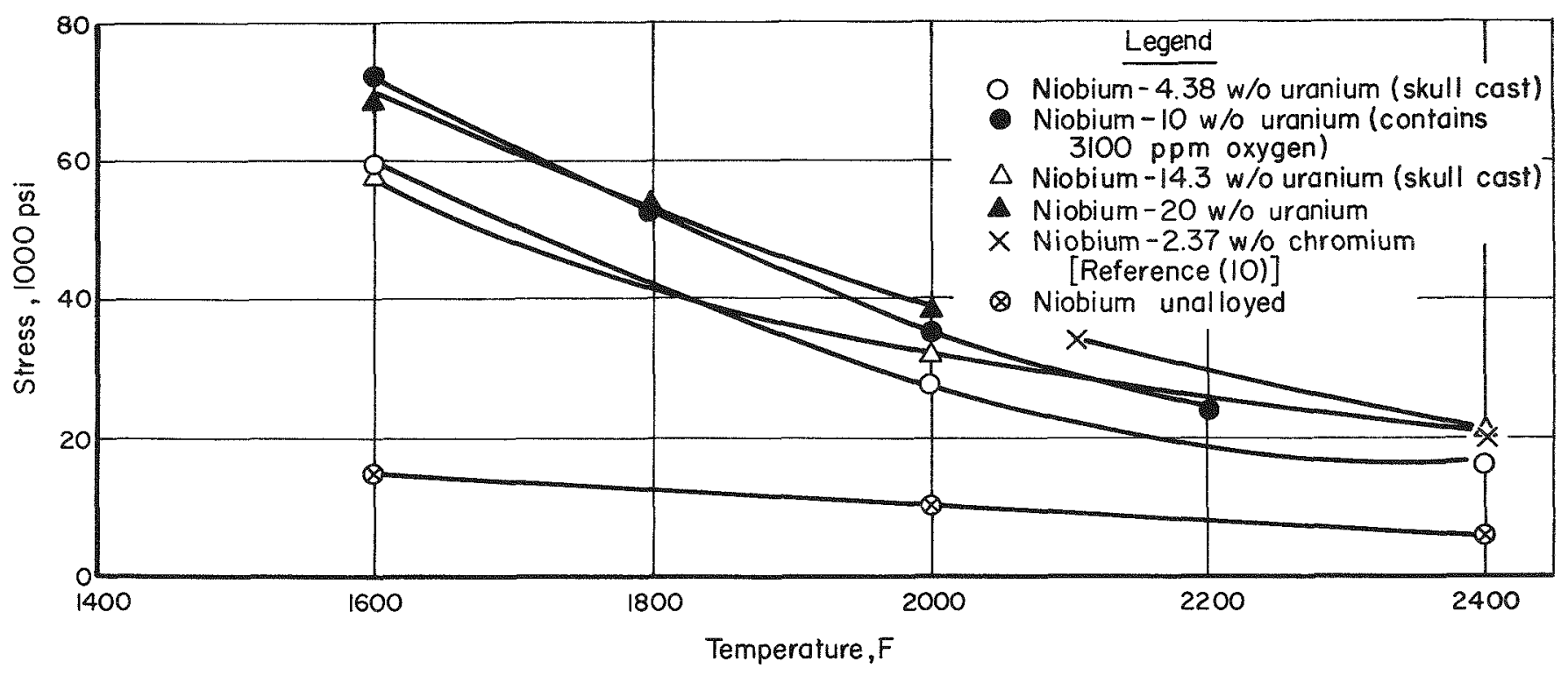

FIGURE 15. COMPARISON OF ELEVATED-TEMPERATURE ULTIMATE TENSILE STRENGTH OF CONSUMABLE-ELECTRODE ARC-MELTED AND SKULL-CAST NIOBIUM-URANIUM ALLOYS

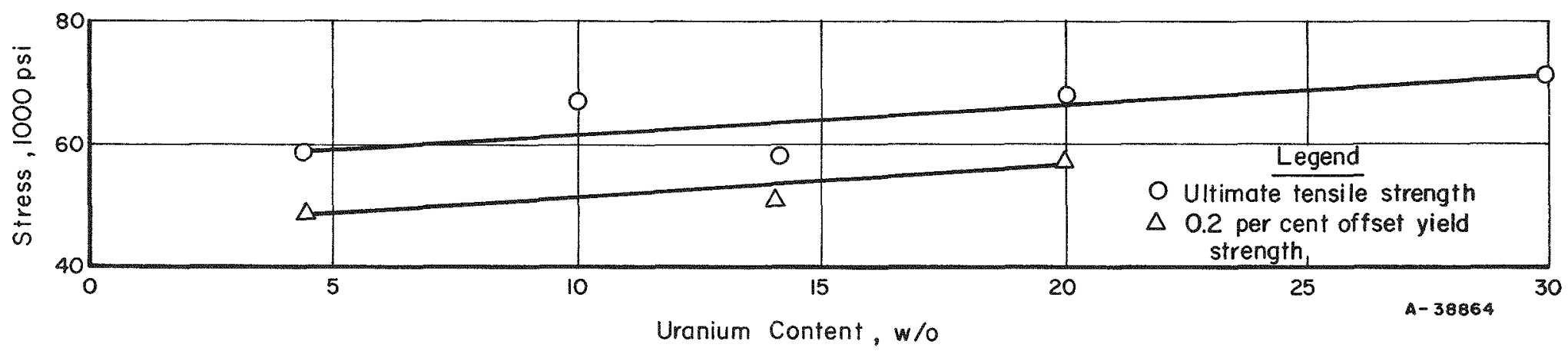

FIGURE 16. EFFECT OF INCREASING URANIUM CONTENT ON THE TENSILE STRENGTH OF NIOBIUM-BASE ALLOYS AT 1600F 


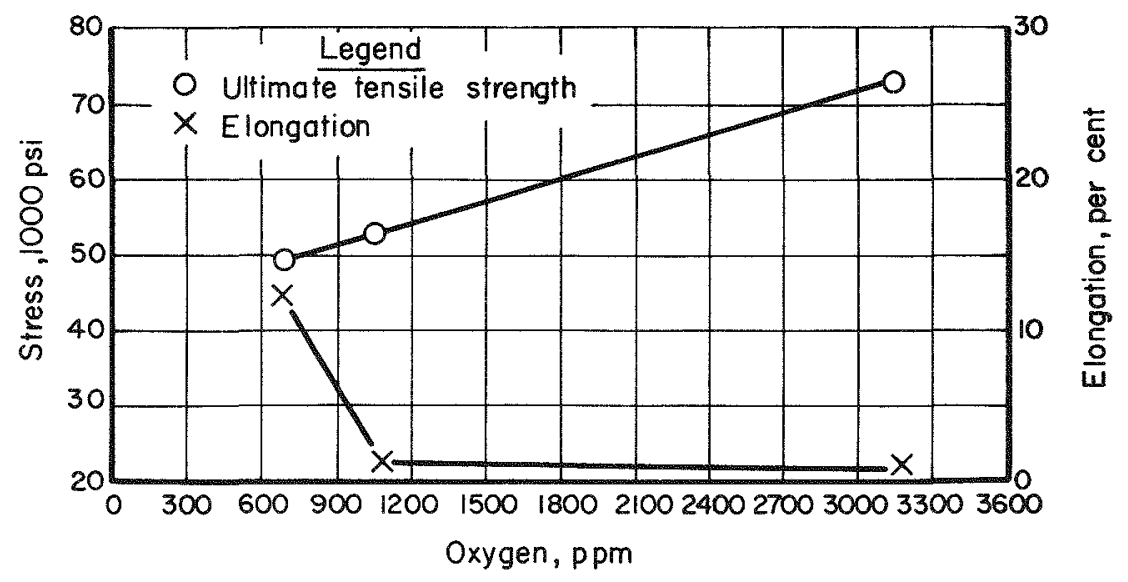

FIGURE 17. EFFECT OF INCREASING OXYGEN CONTENT ON ULTIMATE TENSILE STRENGTH AND ELONGATION OF NIOBIUM-10W/O URANIUM ALLOY AT 1600 F

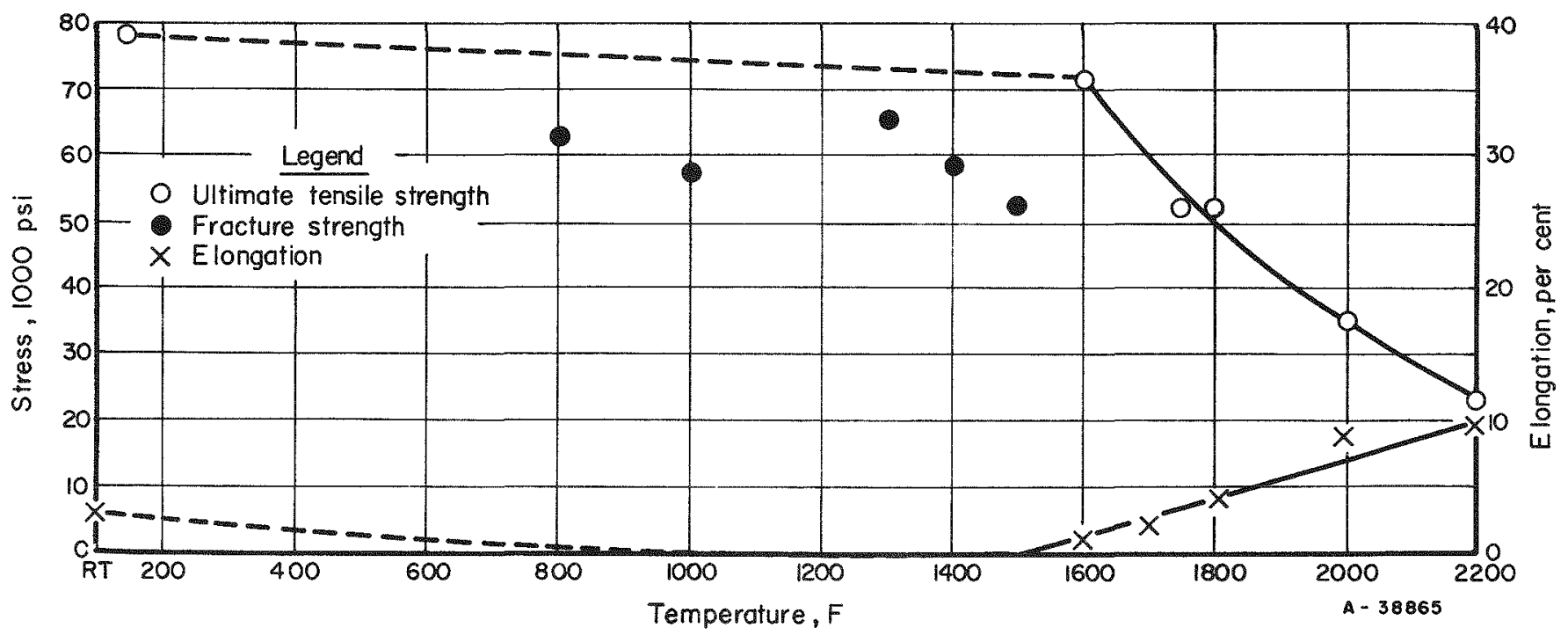


strengths in Figure 18. Above $1500 \mathrm{~F}$ some ductility was noted and the material underwent plastic deformation. Ductility as measured by tensile elongation was low ( 10 per cent) even at $2200 \mathrm{~F}$ where elongations on the order of 80 to 90 per cent could be expected for low-oxygen material.

The effect of oxygen on niobium-10 w/o uranium alloys is important in that it indicates that although $0.3 \mathrm{w} / \mathrm{o}$ oxygen is an effective strengthener of niobium at elevated temperature, the high-oxygen content results in a severe reduction in ductility, which is generally undesirable.

The niobium-uranium alloys possess rather remarkable strength at temperatures up to $2000 \mathrm{~F}$. A glance at Table 9, which compares the tensile strength of the niobiumuranium alloys with that of several commonly used high-strength alloys, shows that the niobium-uranium alloys are as strong or stronger than any alloy listed at $1800 \mathrm{~F}$ and also exhibit comparable ductility. This high strength at elevated temperature negates the need for a cladding material which must support the fuel core. The niobiumuranium alloys appear to need a cladding which will primarily protect them from the coolant and reduce the hazard of radioactive contamination of the coolant.

Creep Studies

The stresses which result in minimum creep rates of $0.001,0.01$, and 0.1 per cent per hr were determined at 1600 and $2000 \mathrm{~F}$ for the niobium-4.38 and $14.3 \mathrm{w} / \mathrm{o}$ uranium alloys and at 1600 and $1800 \mathrm{~F}$ for the niobium-10 and $-20 \mathrm{w} / \mathrm{o}$ uranium alloys. All creep tests were performed in standard creep machines. Vacuum was maintained at about $5 \times 10^{-4} \mathrm{~mm}$ of mercury and temperatures were controlled to about $\pm 5 \mathrm{~F}$ for each test. A filar microscope was used to measure creep deformation. Results are shown in Table 10 and are plotted in Figures 19 and 20.

In Figure 20, the creep rates for all four alloys tested are compared. As can be seen, all four alloys follow the same general slope at $1600 \mathrm{~F}$. The niobium-10 w/o uranium alloy follows the same general slope even though it had been strengthened additionally through accidental contamination by oxygen as well as the addition of uranium.

A summary of the stresses that will produce creep rates of $0.001,0.01$, and 0.1 per cent per hour is shown in Table 11 .

Design curves for the niobium -4.38 and $-14.3 \mathrm{w} / \mathrm{o}$ uranium alloys are presented in Figures 21 and 22. These figures show rupture curves and also curves representing various percentages of total deformation as related to specific stresses and times of application. Curves were not prepared for the niobium-10 and $-20 \mathrm{w} / 0$ uranium alloys as data for these alloys were not complete.

The creep strength obtained for the niobium-10 w/o uranium alloy is higher than expected, this is undoubtedly due to the high oxygen content of this alloy as discussed in the previous section. Chemical analyses of the niobium $-4.38 \mathrm{w} / 0$ uranium alloy indicate that $1100 \mathrm{ppm}$ oxygen is present in this alloy which probably explains why its creep strength is higher than that of either the niobium-14.3 (contains $160 \mathrm{ppm}$ oxygen) or $-20 \mathrm{w} / \mathrm{o}$ (contains $198 \mathrm{ppm}$ oxygen) uranium alloy. Contamination of the niobium-4. 38 and $-10 \mathrm{w} / \mathrm{o}$ uranium alloy creep specimens with oxygen probably occurred during vacuum stress-relief annealing. 
TABLE 9. COMPARISON OF SHORT-TIME TENSILE PROPERTIES OF NIOBIUMURANIUM ALLOYS AND SELECTED STRUCTURAL MATERIALS

\begin{tabular}{|c|c|c|c|c|c|}
\hline Material & $\begin{array}{c}\text { Temperature, } \\
\text { F }\end{array}$ & $\begin{array}{c}0.2 \text { Per Cent } \\
\text { Offset Yield } \\
\text { Strength, } \\
\text { psi }\end{array}$ & $\begin{array}{c}\text { Ultimate } \\
\text { Tensile } \\
\text { Strength, } \\
\text { psi }\end{array}$ & $\begin{array}{l}\text { Elongation, } \\
\text { per cent }\end{array}$ & Reference \\
\hline $\mathrm{Nb}-4.38 \mathrm{w} / \mathrm{OU}$ & $\begin{array}{l}1600 \\
2000 \\
2400\end{array}$ & $\begin{array}{r}49,850 \\
16,880 \\
8,500\end{array}$ & $\begin{array}{l}58,940 \\
27,420 \\
15,600\end{array}$ & $\begin{array}{l}9.0 \\
2.5 \\
6.6\end{array}$ & $\begin{array}{l}-- \\
-- \\
--\end{array}$ \\
\hline $\mathrm{Nb}-10 \mathrm{w} / 0 \mathrm{U}$ & $\begin{array}{l}1600 \\
1800 \\
2000 \\
2200\end{array}$ & $\begin{array}{c}-- \\
44,600 \\
25,400 \\
--\end{array}$ & $\begin{array}{l}72,000 \\
52,500 \\
35,300 \\
24,000\end{array}$ & $\begin{array}{r}1 \\
4.0 \\
9.0 \\
10.0\end{array}$ & $\begin{array}{l}-- \\
-- \\
-- \\
--\end{array}$ \\
\hline $\mathrm{Nb}-14.3 \mathrm{w} / \mathrm{oU}$ & $\begin{array}{l}1600 \\
2000 \\
2400\end{array}$ & $\begin{array}{l}50,970 \\
22,370 \\
10,200\end{array}$ & $\begin{array}{l}57,060 \\
32,870 \\
21,100\end{array}$ & $\begin{array}{l}14.0 \\
57.0 \\
66.0\end{array}$ & $\begin{array}{l}-- \\
-- \\
--\end{array}$ \\
\hline $\mathrm{Nb}-20 \mathrm{w} / \mathrm{OU}$ & $\begin{array}{r}75 \\
1600 \\
1800 \\
2000\end{array}$ & $\begin{array}{l}93,200 \\
58,100 \\
43,000 \\
28,600\end{array}$ & $\begin{array}{r}102,000 \\
68,400 \\
52,000 \\
37,500\end{array}$ & $\begin{array}{r}7 \\
10 \\
34 \\
74\end{array}$ & $\begin{array}{l}(1) \\
(1) \\
-- \\
--\end{array}$ \\
\hline Unalloyed niobium & $\begin{array}{r}75 \\
1600 \\
2000 \\
2400\end{array}$ & $\begin{array}{r}36,000 \\
9,400 \\
8,100 \\
4,000\end{array}$ & $\begin{array}{r}48,000 \\
15,200 \\
10,100 \\
5,500\end{array}$ & $\begin{array}{l}48 \\
47 \\
34 \\
70\end{array}$ & $\begin{array}{l}(6) \\
-- \\
-- \\
--\end{array}$ \\
\hline Type 304 stainless & $\begin{array}{r}75 \\
1500 \\
1900\end{array}$ & $\begin{array}{c}34,000 \\
10,000 \\
=-\end{array}$ & $\begin{array}{r}85,000 \\
21,000 \\
7,000\end{array}$ & $\begin{array}{l}63 \\
39 \\
63\end{array}$ & $\begin{array}{l}(7) \\
-- \\
--\end{array}$ \\
\hline Type 316 stainless & $\begin{array}{r}75 \\
1500 \\
1900\end{array}$ & $\begin{array}{c}38,500 \\
18,500 \\
=-\end{array}$ & $\begin{array}{l}85,500 \\
27,500 \\
10,500\end{array}$ & $\begin{array}{c}60 \\
42 \\
--\end{array}$ & $\begin{array}{l}(7) \\
-- \\
--\end{array}$ \\
\hline Hastelloy $X$ & $\begin{array}{r}75 \\
1800 \\
2300\end{array}$ & $\begin{array}{c}55,800 \\
17,000 \\
--\end{array}$ & $\begin{array}{r}113,000 \\
21,000 \\
3,300\end{array}$ & $\begin{array}{l}43 \\
43 \\
21\end{array}$ & $\begin{array}{l}(8) \\
-- \\
--\end{array}$ \\
\hline René 41 & $\begin{array}{l}\mathrm{RT} \\
1650 \\
1800\end{array}$ & $\begin{array}{r}140,000 \\
75,000 \\
35,000\end{array}$ & $\begin{array}{r}185,000 \\
75,000 \\
35,000\end{array}$ & $\begin{array}{l}20 \\
12 \\
20\end{array}$ & $\begin{array}{l}(9) \\
-- \\
--\end{array}$ \\
\hline
\end{tabular}


TABLE 10. CREEP DATA ON NIOBIUM-BASE ALLOYS TESTED IN VACUUM

\begin{tabular}{|c|c|c|c|c|c|c|c|c|c|}
\hline $\begin{array}{c}\text { Alloy Composition } \\
\text { (Balance Niobium), } \\
\text { w/o }\end{array}$ & $\begin{array}{l}\text { Temperature, } \\
\text { F }\end{array}$ & $\begin{array}{l}\text { Stress, } \\
\text { psi }\end{array}$ & $\begin{array}{l}\text { Rupture } \\
\text { T'ime, } \\
\text { hr }\end{array}$ & $\begin{array}{c}\text { Initial } \\
\text { Deformation, } \\
\text { per cent }\end{array}$ & \multicolumn{3}{|c|}{$\begin{array}{l}\text { Deformation, per cent, } \\
\text { After Indicated Time }\end{array}$} & $\begin{array}{c}\text { Minimum } \\
\text { Creep Rate, } \\
\text { per cent per hr }\end{array}$ & $\begin{array}{c}\text { Total } \\
\text { Elongation, } \\
\text { per cent }\end{array}$ \\
\hline \multirow[t]{2}{*}{$4.38 \mathrm{U}$} & 1600 & 35,000 & 41.4 & 0.396 & 2.48 & -- & -- & 0.175 & 16.5 \\
\hline & & 20,000 & $575.0^{(a)}$ & -0.010 & 0.235 & 0.735 & 4.77 & 0.005 & 5.75 \\
\hline \multirow[t]{4}{*}{$14.3 \mathrm{U}$} & 1600 & 35,000 & 8.7 & 0.593 & -- & -- & - & 1.86 & 43.3 \\
\hline & & 30,000 & 17,5 & -0.021 & -- & - & - & 0.012 & 8.25 \\
\hline & & 20,000 & $337.6(b)$ & 0.161 & 1.05 & 3.94 & - & 0.029 & 13.9 \\
\hline & & 10,000 & $785.9^{(\mathrm{c})}$ & 0.067 & 0.162 & 0.325 & 0.622 & 0.0007 & 0.778 \\
\hline \multirow[t]{2}{*}{$4.38 \mathrm{U}$} & 2000 & 10,000 & 238.2 & 0.191 & 2.40 & 10.50 & $m$ & 0.081 & 30.9 \\
\hline & & 5,000 & $145.1^{(b)}$ & 0.182 & 0.450 & 0.745 & -- & 0.002 & 0.807 \\
\hline \multirow[t]{4}{*}{$14.3 \mathrm{U}$} & 2000 & 10,000 & 127.1 & 0.500 & 7.80 & 22.8 & $-\infty$ & 0.156 & 27.8 \\
\hline & & 5,000 & $11.0^{(\mathrm{c})}$ & 0.075 & -. & - & $\ldots$ & 0.15 & 2.2 \\
\hline & & 5,000 & $19.2^{(d)}$ & -. & - & -- & $-\infty$ & - & $\ldots$ \\
\hline & & 4,000 & $157.4^{(c)}$ & 0.043 & 0.42 & 0.92 & - & 0.0025 & 1.0 \\
\hline \multirow[t]{5}{*}{$10 \mathrm{U}$} & 1600 & 30,000 & 60.2 & -. & -- & -- & -- & 0.71 & 1.0 \\
\hline & & 25,000 & 381.3 & -. & -- & - & $m$ & 0.0052 & 6.0 \\
\hline & & 20,000 & $169.0^{(b)}$ & $\cdots$ & -- & -- & $-\infty$ & 0.0028 & 0.8 \\
\hline & 1800 & 20,000 & 28.9 & -- & -. & $m$ & -. & 0.036 & 14.0 \\
\hline & & 14,000 & 54.0 & -- & -- & -- & - & 0.20 & 15.0 \\
\hline \multirow[t]{3}{*}{$20 \mathrm{U}$} & 1600 & 30,000 & 38.7 & -- & -. & -- & -- & 0.71 & 82.7 \\
\hline & 1800 & 20,000 & 27.2 & $-\infty$ & -- & -- & $-\infty$ & 1.16 & 71.0 \\
\hline & & 15,000 & 169.7 & -- & -- & -. & -- & 0.122 & 93.0 \\
\hline
\end{tabular}

(a) Test in progress.

(b) Test discontinued.

(c) Test failed due to flaw in material.

(d) Test discontinued, extensometer was not readable. 

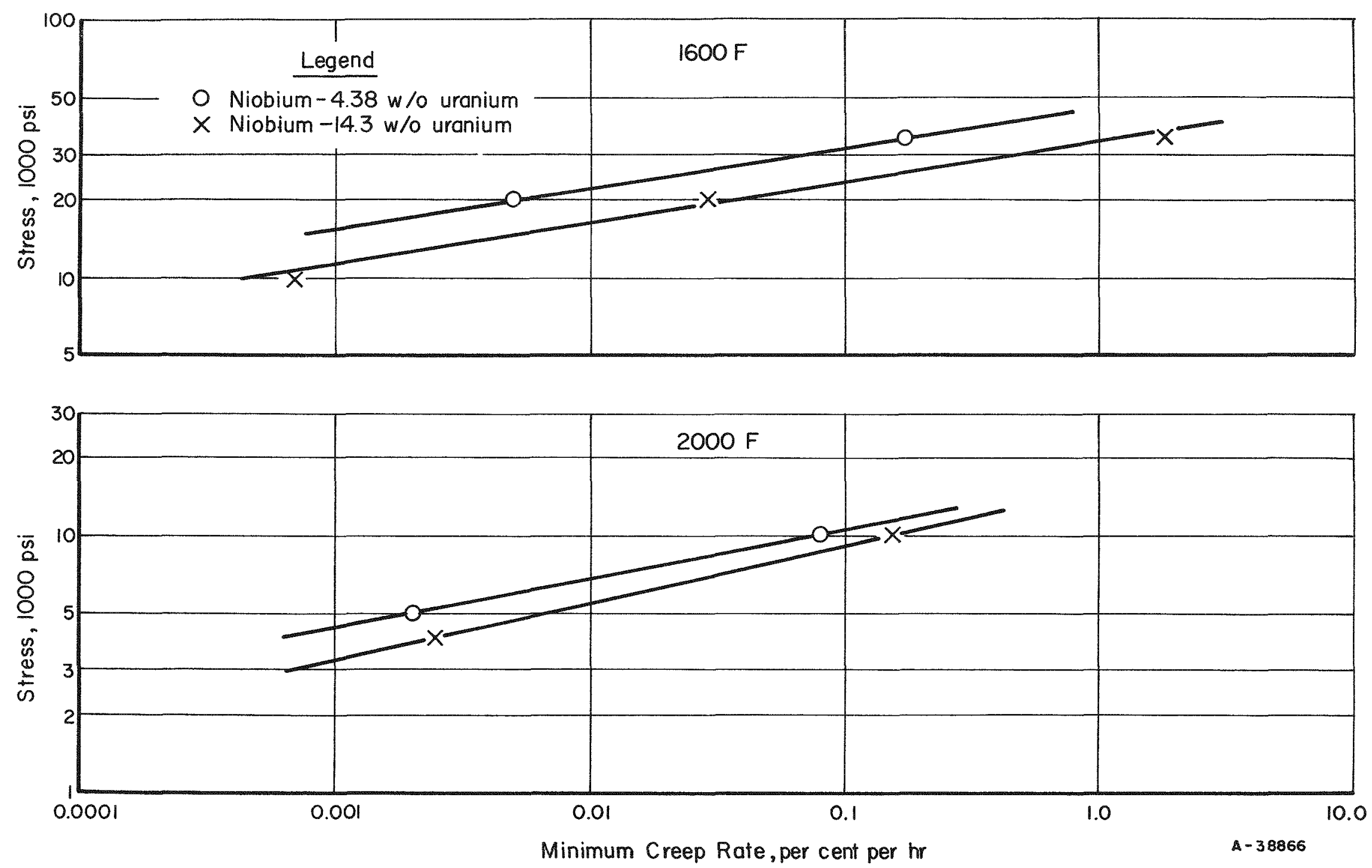

FIGURE 19. STRESS VERSUS MINIMUM CREEP RATE FOR TWO NIOBIUM-BASE ALLOYS AT 1600 AND 2000 F 

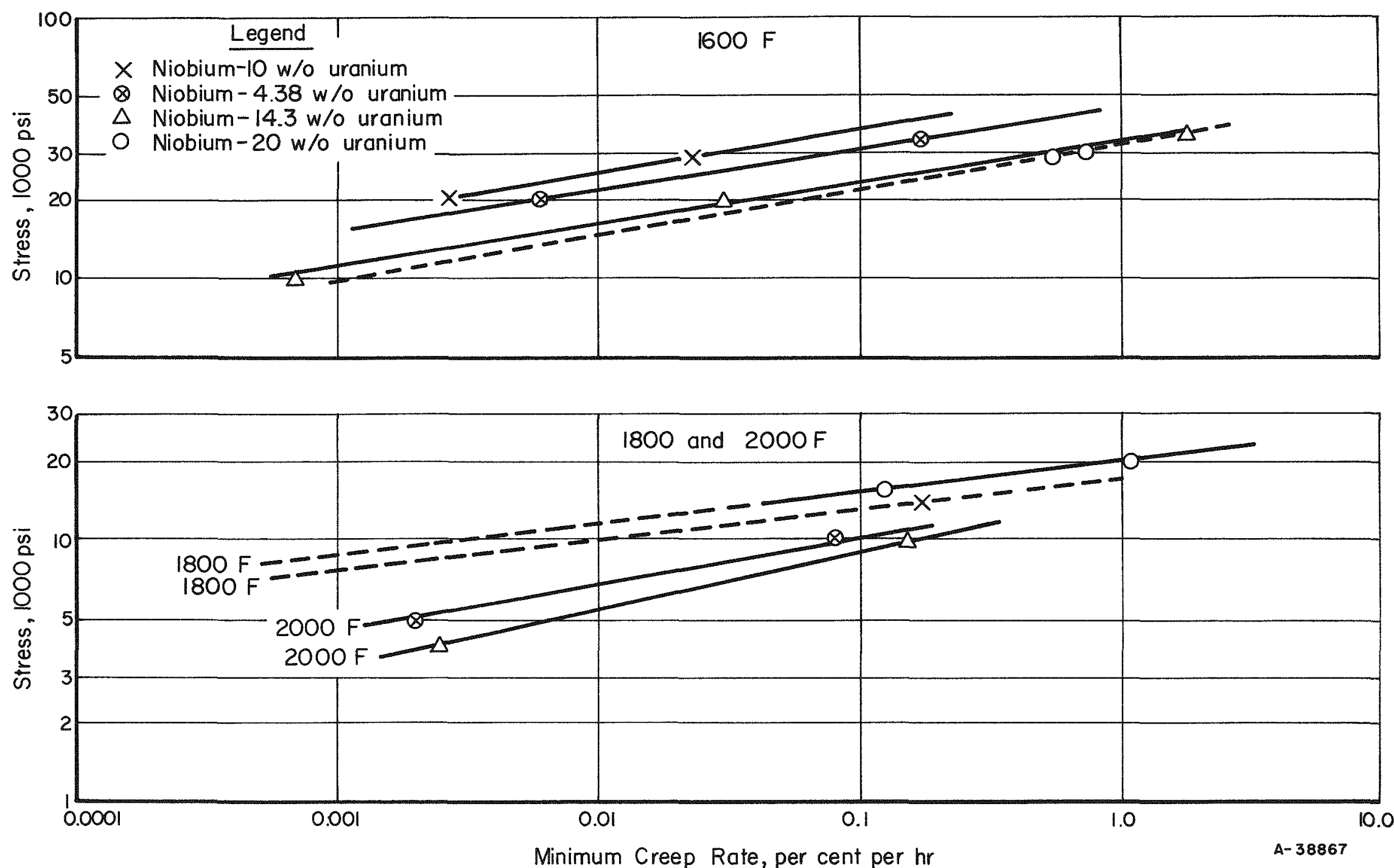

FIGURE 20. COMPARISON OF STRESS VERSUS MINIMUM CREEP RATES FOR FOUR NIOBIUM-URANIUM ALLOYS AT 1600,1800 , AND $2000 \mathrm{~F}$ 
TABLE 11. STRESS TO PRODUCE CREEP RATES OF 0.001, 0.01, AND 0.1 PER CENT PER HR IN NIOBIUM-URANIUM ALLOYS

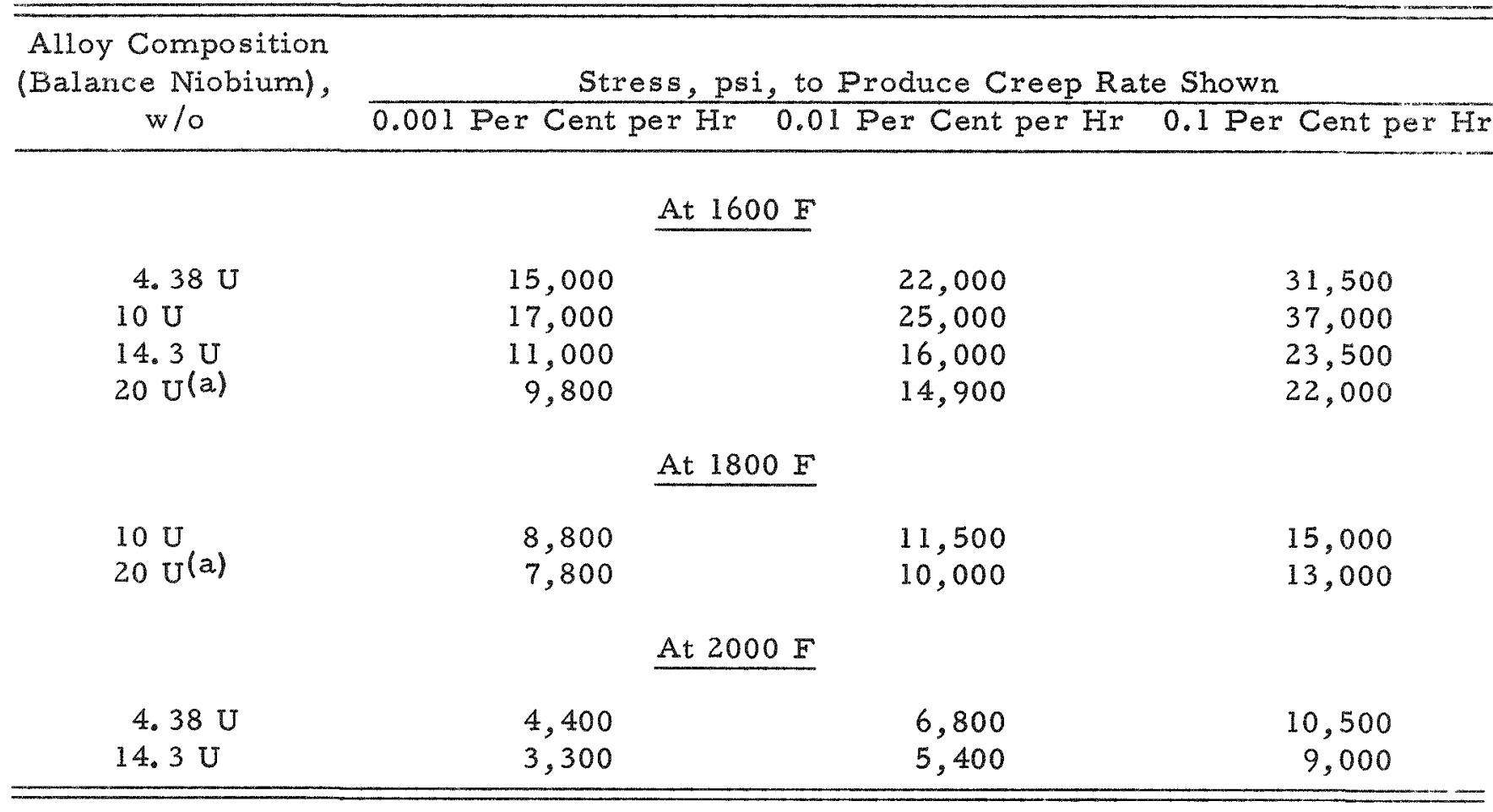

(a) Stresses are estimated.

The data presented above indicate that the niobium-uranium alloys tested have creep strengths which are comparable to many structural materials. The strengths exhibited are more than sufficient for a fuel alloy and further indicate that a cladding material will be needed only to prevent corrosion and to contain fission products.

\section{CORROSION-TEST RESULTS}

Corrosion tests were performed to evaluate the behavior of niobium-uraniun alloys in potential reactor coolants. The coolants studied were $\mathrm{NaK}$ at $1600 \mathrm{~F}$, sodium at $1500 \mathrm{~F}$, and water at 600 and $680 \mathrm{~F}$.

In $\mathrm{NaK}$ and Sodium

Fabricated specimens of niobium -10 and $-20 \mathrm{w} / 0$ uranium and as-cast specimens of niobium $-30,-40,-50$, and $-60 \mathrm{w} / \mathrm{o}$ uranium were exposed to $\mathrm{NaK}$ at $1600 \mathrm{~F}$ and sodium at $1500 \mathrm{~F}$. Testing was conducted in NaK because it is a commonly used heat-transfer medium in irradiation studies. Compatibility with sodium was determined since sodium is used as a reactor coolant. The experimental procedure was identical for testing in both media. Specimens were placed in stainless steel capsules which contained sufficient $\mathrm{NaK}$ (potassium-44 w/o sodium) or sodium to completely immerse the specimens. 

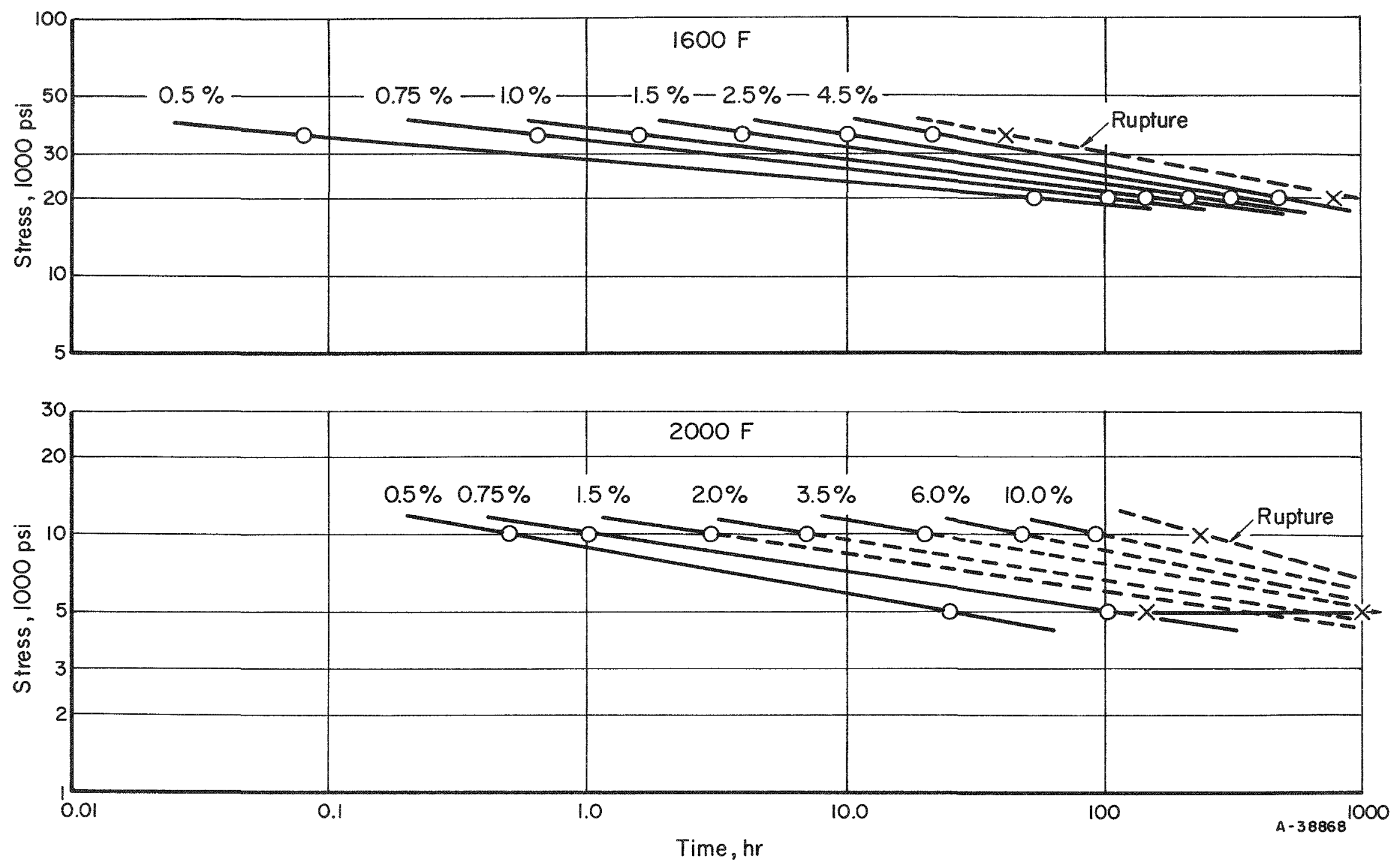

FIGURE 21. DESIGN CURVE FOR NIOBIUM-4. $38 \mathrm{w} / 0$ URANIUM ALLOY AT 1600 AND $2000 \mathrm{~F}$ 

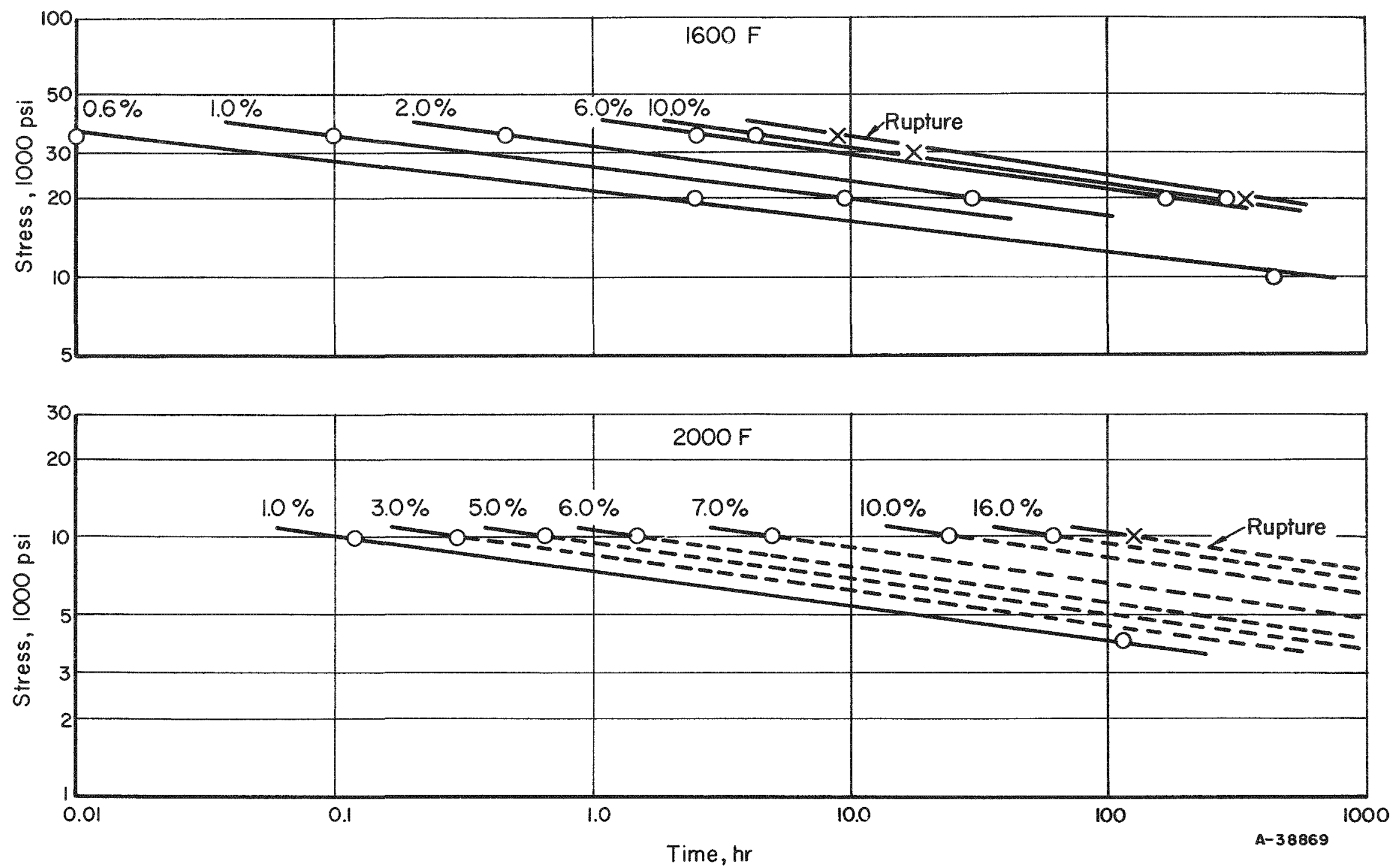

FIGURE 22. DESIGN CURVE FOR NIOBIUM-14.3 w/0 URANIUM ALLOY AT 1600 AND $2000 \mathrm{~F}$ 
Closure of the capsules was accomplished by welding end plugs in place in a heliumfilled dry box. The capsules, each of which contained two specimens, were placed in a stainless steel can which had a thermocouple well so fixed that temperature measurements could be made at the center of the capsule-containing shell. Tests were run in duplicate.

Specimens tested in $\mathrm{NaK}$ were examined and weighed after exposures of 156,656 , and $1000 \mathrm{hr}$. A summary of data obtained is shown in Table 12. Representative specimens of niobium-uranium alloys before and after exposure are shown in Figure 23. Specimens tested in sodium at $1500 \mathrm{~F}$ were examined after exposures of 500,1000 , and $1500 \mathrm{hr}$. The weight-change data for these tests are shown in Table 13. Figure 24 shows representative specimens of the niobium-uranium alloys before and after exposure to sodium. The surfaces of specimens prior to testing were quite rough. The surfaces were tested in this condition so that the maximum surface area would be exposed. No gross surface attack by either $\mathrm{NaK}$ or sodium occurred as is shown by the macrographs; the stain observed was introduced during cleaning.

TABLE 12. CORROSION DATA FOR NIOBIUM-URANIUM ALLOYS(a) IN NaK AT $1600 \mathrm{~F}$

\begin{tabular}{|c|c|c|c|c|c|c|}
\hline \multirow{3}{*}{$\begin{array}{c}\text { Alloy Composition } \\
\text { (Balance Niobium), } \\
\text { w/o }\end{array}$} & \multicolumn{2}{|c|}{ Impurity Content } & \multirow{3}{*}{$\begin{array}{l}\text { Specimen } \\
\text { Condition }\end{array}$} & \multirow{2}{*}{\multicolumn{3}{|c|}{$\begin{array}{c}\text { Total Weight Change, } \\
\text { mg per } \mathrm{cm}^{2} \text {, After } \\
\text { Indicated. Time }\end{array}$}} \\
\hline & \multirow{2}{*}{$\begin{array}{l}\text { Oxygen }(b) \\
\text { ppm }\end{array}$} & \multirow{2}{*}{$\begin{array}{c}\text { Zirconium(c), } \\
\text { w/o }\end{array}$} & & & & \\
\hline & & & & $156 \mathrm{Hr}$ & $656 \mathrm{Hr}$ & $1000 \mathrm{Hr}$ \\
\hline $10 \mathrm{U}$ & 680 & 0.74 & Fabricated & 0 & 0.17 & 0.14 \\
\hline & 1190 & 0.17 & Fabricated & -0.66 & 0.05 & -1.01 \\
\hline & 3170 & 0.02 & Fabricated & -0.33 & -0.03 & -0.31 \\
\hline $20 \mathrm{U}$ & 458 & 0.74 & Fabricated & 0.92 & 0.37 & 1.25 \\
\hline & 523 & 0.17 & Fabricated & 0.67 & 0.14 & 0.93 \\
\hline & 198 & 0.02 & Fabricated & 0.31 & 0.25 & 0.69 \\
\hline $30 \mathrm{U}$ & 165 & 0.02 & As cast & 0.93 & 0.52 & 2.09 \\
\hline $40 \mathrm{U}$ & 261 & 0.02 & As cast & 1. 48 & 0.38 & 2.51 \\
\hline $50 \mathrm{U}$ & 271 & 0.02 & As cast & 0.96 & 0.55 & 2.50 \\
\hline $60 \mathrm{U}$ & 192 & 0.02 & As cast & 1.36 & 1.15 & 3.24 \\
\hline
\end{tabular}

(a) Values are averages from two specimens.

(b) Analyzed values.

(c) Nominal composition. 


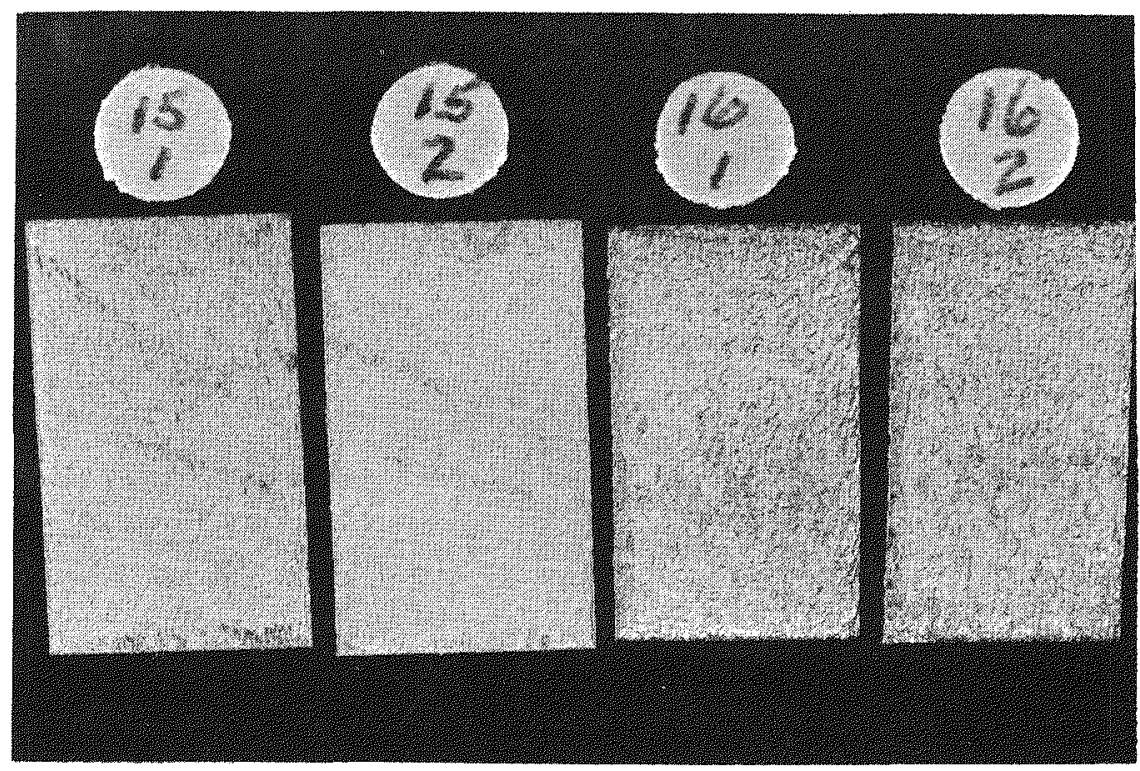

$2 \mathrm{X}$

RM12978

a. Before Exposure to NaK

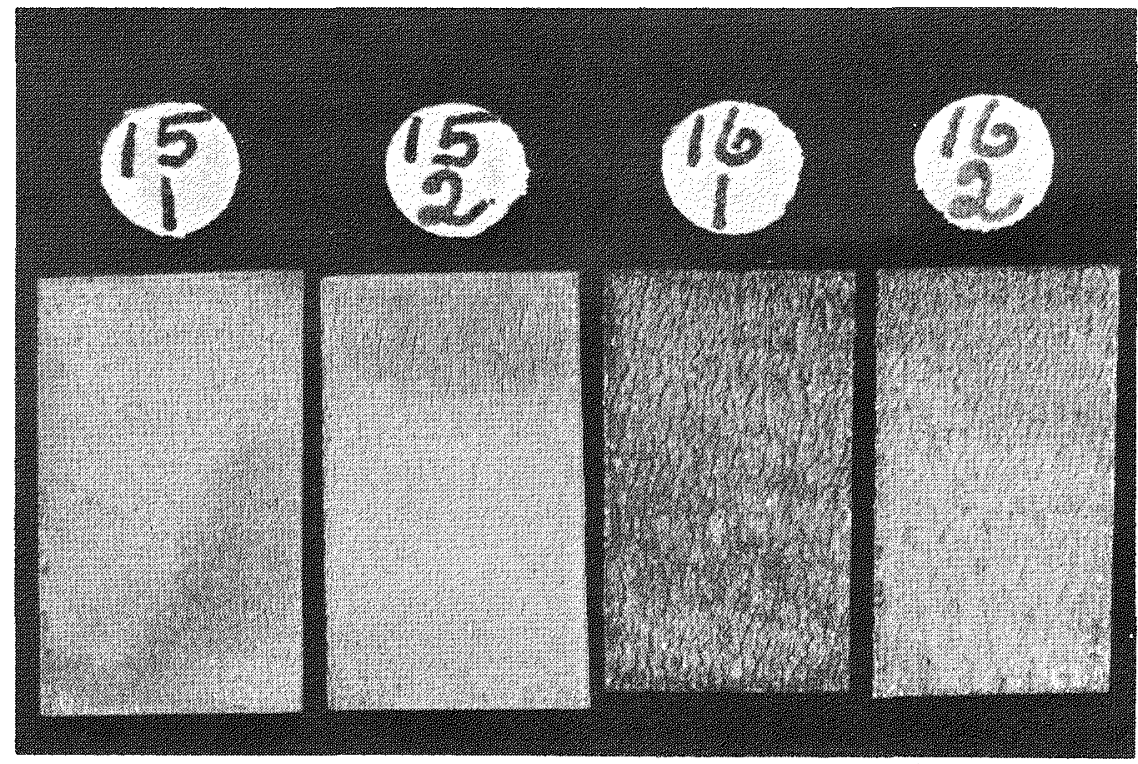

$2 X$

RM14752

b. After Exposure to $\mathrm{NaK}$ at $1600 \mathrm{~F}$ for $1000 \mathrm{Hr}$

FIGURE 23. NIOBIUM-10 AND - 20 w/o URANIUM ALLOYS BEFORE AND AFTER EXPOSURE TO NaK AT $1600 \mathrm{~F}$

Specimens 16-1 and 16-2 were niobium-10 w/o uranium alloys; Specimens $15-1$ and $15-2$ were niobium-20 w/o uranium alloys. 


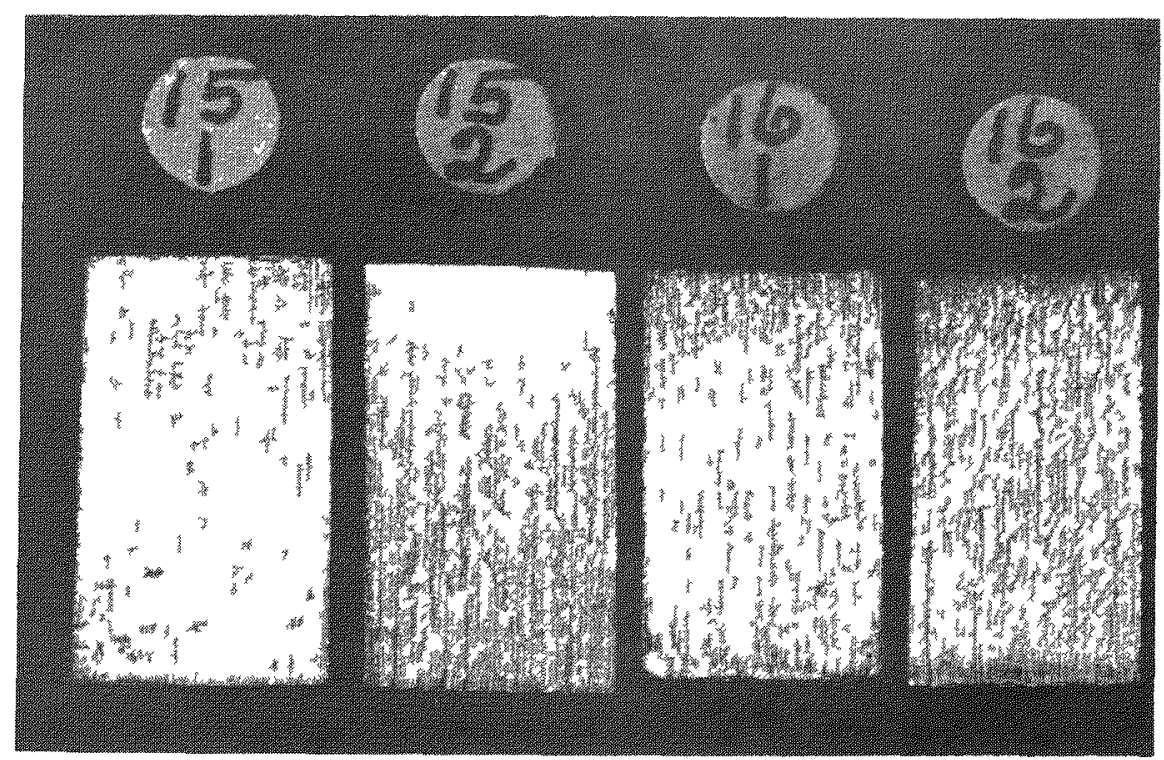

$2 X$

RM14829

a. Before Exposure to Sodum

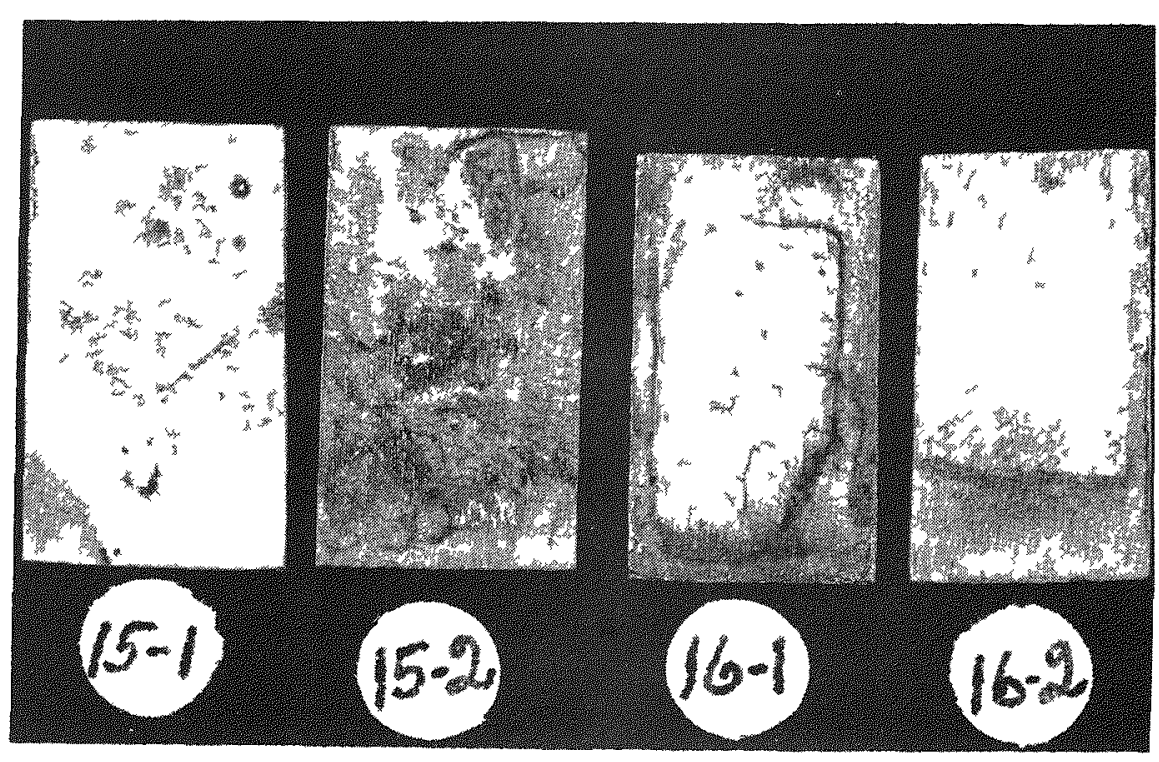

$2 \mathrm{X}$

b. After Exposure to Sodium at $1500 \mathrm{~F}$ for $1500 \mathrm{Hr}$

RM16582

FIGURE 24. NIOBIUM-10 AND - 20 W/o URANIUM ALLOYS BEFORE AND AFTER EXPOSURE TO SODIUM AT $1500 \mathrm{~F}$

Specimens 16-1 and 16-2 are niobium-10 w/o uranium alloys, Specimens $15-1$ and $15-2$ are niobium- $20 \mathrm{w} / 0$ uranum alloys. 
TABLE 13. CORROSION DATA FOR NIOBIUM-URANIUM ALLOYS(a) EXPOSED TO SODIUM AT $1500 \mathrm{~F}$

\begin{tabular}{|c|c|c|c|c|c|c|}
\hline \multirow{2}{*}{$\begin{array}{c}\text { Alloy Content } \\
\text { (Balance Niobium), } \\
\text { w/o }\end{array}$} & \multicolumn{2}{|c|}{ Impurity Content } & \multirow{2}{*}{$\begin{array}{l}\text { Specimen } \\
\text { Condition }\end{array}$} & \multicolumn{3}{|c|}{$\begin{array}{c}\text { Total Weight Change, } \\
\text { mg per } \mathrm{cm}^{2} \text {, After } \\
\text { Indicated Time }\end{array}$} \\
\hline & ppm & w/o & & $500 \mathrm{Hr}$ & $1000 \mathrm{Hr}$ & $1500 \mathrm{Hr}$ \\
\hline \multirow{3}{*}{$10 \mathrm{U}$} & 680 & 0.74 & Fabricated & 0.03 & -0.06 & -0.08 \\
\hline & 1190 & 0.17 & Fabricated & 0.05 & 0.07 & 0.15 \\
\hline & 3170 & 0.02 & Fabricated & -0.10 & -0.41 & -0.41 \\
\hline \multirow[t]{3}{*}{$20 \mathrm{U}$} & 458 & 0.74 & Fabricated & 0.15 & -0.30 & -1.04 \\
\hline & 523 & 0.17 & Fabricated & 0.17 & 0.52 & 0.64 \\
\hline & 198 & 0.02 & Fabricated & -0.04 & 0.10 & 0.10 \\
\hline $30 \mathrm{U}$ & 165 & 0.02 & As cast & 0.18 & 0.89 & 1.70 \\
\hline $40 \mathrm{U}$ & 261 & 0.02 & As cast & 0.55 & 1.78 & 2.32 \\
\hline $50 \mathrm{U}$ & 271 & 0.02 & As cast & 0.49 & 3.32 & 4.45 \\
\hline
\end{tabular}

(a) Values are averages from two specimens.

(b) Analyzed values.

(c) Nominal composition.

The source of the weight changes which occur during exposure is the oxygen contained in the sodium and $\mathrm{NaK}$. Both contained approximately $50 \mathrm{ppm}$ oxygen with the oxygen being reintroduced during each capsule opening for weight measurements. Examination of the weight-change data for the NaK and sodium exposures indicates that increased weight gains accompany increases in uranium content. This is illustrated graphically in Figure 25, which shows a plot of weight gain versus uranium content.

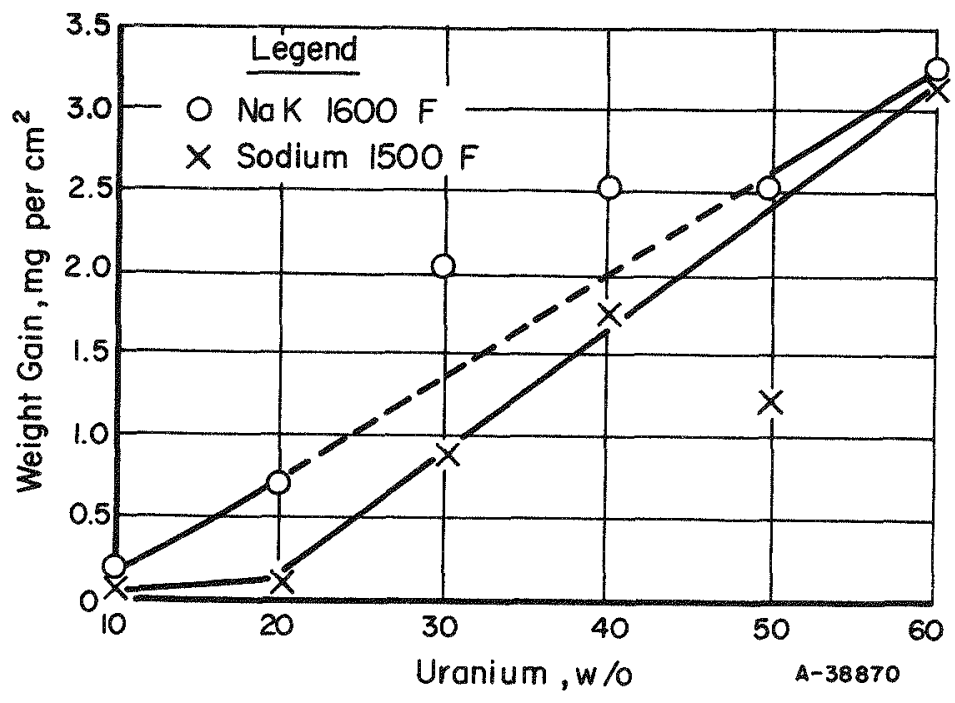

FIGURE 25. EFFECT OF INCREASING URANIUM CONTENT ON WEIGHT GAIN OF NIOBIUM IN NaK AT 1600 F AND SODIUM AT 1500 F FOR 1000 -HR TEST 
Specimens tested in sodium were examined-metallographically to determine the extent, if any, of oxygen penetration. Figures $26 \mathrm{a}$ and $26 \mathrm{~b}$ show a cross-sectional view of the niobium -10 and $-20 \mathrm{w} / 0$ uranium alloys respectively. No obvious penetration or oxide layer was noted in these alloys. Apparently, the weight gains observed are a result of either or both the formation of a very thin surface oxide or the solution of oxygen in the alloys. While oxygen is fairly soluble in niobium, it is expected that the addition of uranium will decrease this solubility, although the extent of the decrease cannot be predicted.

Figure 27 shows the surface of the niobium-60w/o uranium sample which had experienced a large weight gain. This particular alloy sample was tested in the as-cast condition and dark appearing uranium-rich dendrites are seen in the bulk of the material. However, a change in structure is observed in the area just below the surface of the specimen. In the higher magnification in the as-polished condition, it is evident that this change in structure is the result of internal oxidation. It appears that the uraniumrich dendrites provide a path for oxygen diffusion which leads to the probable formation of uranium dioxide.

These results indicate that niobium-uranium alloys containing less than $60 \mathrm{w} / 0$ uranium are highly resistant to attack by either $\mathrm{NaK}$ or sodium even if oxygen is present in the liquid metal. In the absence of oxygen, little attack by either sodium or NaK would be expected.

The above experimental results indicate that the niobium-uranium alloys containing less than $60 \mathrm{w} / 0$ uranium are highly resistant to attack by either NaK or sodium and, in fact, would probably remain relatively unaffected if exposed to oxygen-free NaK or sodium.

In Water

Tests in 600 and $680 \mathrm{~F}$ water were conducted for 336 and 140 days, respectively. Plate-type specimens were prepared for testing by machining approximately 0.0007 in. from each specimen surface and pickling in a solution of nitric acid, water, and HF to remove an additional 0.0002 in. from the surface. The specimens were then weighed and placed in autoclaves for testing. All tests were performed in duplicate.

In order to evaluate the effect of impurity content on corrosion behavior of the alloys, vacuum-fusion and chemical analyses were obtained on material which was taken from the area adjacent to that from which the test specimens were prepared. These analyses are shown in Table 14. A majority of the niobium-uranium specimens contain less than $600 \mathrm{ppm}$ oxygen, although a few contain over $1000 \mathrm{ppm}$.

A summary of weight changes observed in $600 \mathrm{~F}$ water for 336 days of exposure is shown in Table 15. Although specimens were examined and weighed every 14 days, only data for 1-month intervals are shown. No obvious trend in corrosion rate with change in uranium content up to $50 \mathrm{w} / \mathrm{o}$ uranium is apparent from the data. However, the $60 \mathrm{w} / \mathrm{o}$ uranium alloy shows a definitely higher corrosion weight loss as compared with the remaining alloys. Also, from the data for the $10 \mathrm{w} / \mathrm{o}$ uranium alloy, it can be concluded that corrosion resistance decreases when oxygen content becomes excessive, greater than about $1000 \mathrm{ppm}$ for this particular alloy. 


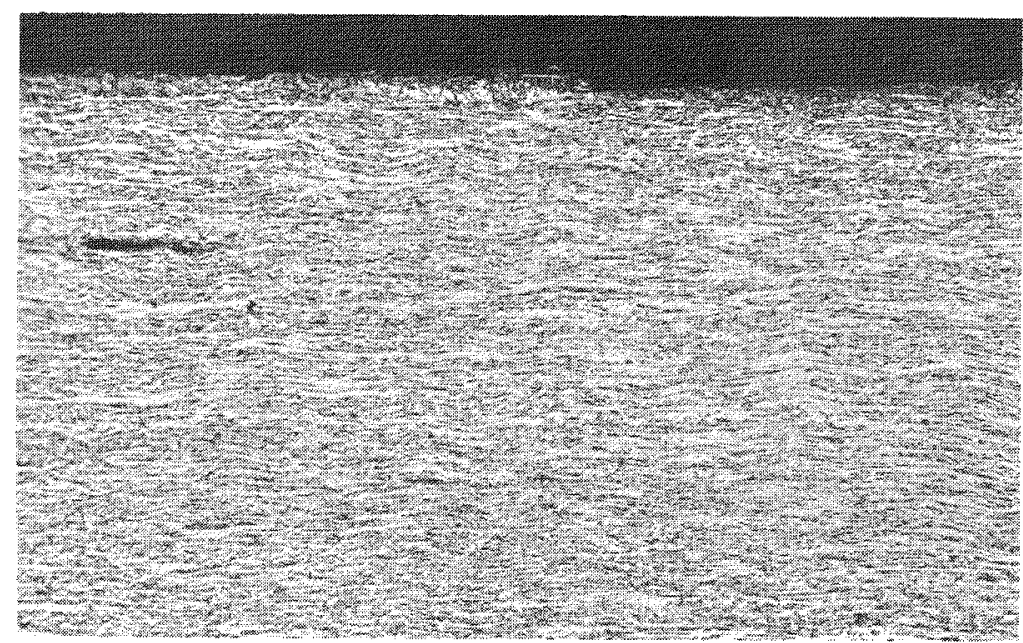

a. Niobium-10 w/o Uranium Alloy

No penetration occurred. Structure is that of heavily worked material. Alloy contained $680 \mathrm{ppm}$ oxygen. Total weight gain was $0.15 \mathrm{mg}$ per $\mathrm{cm}^{2}$.

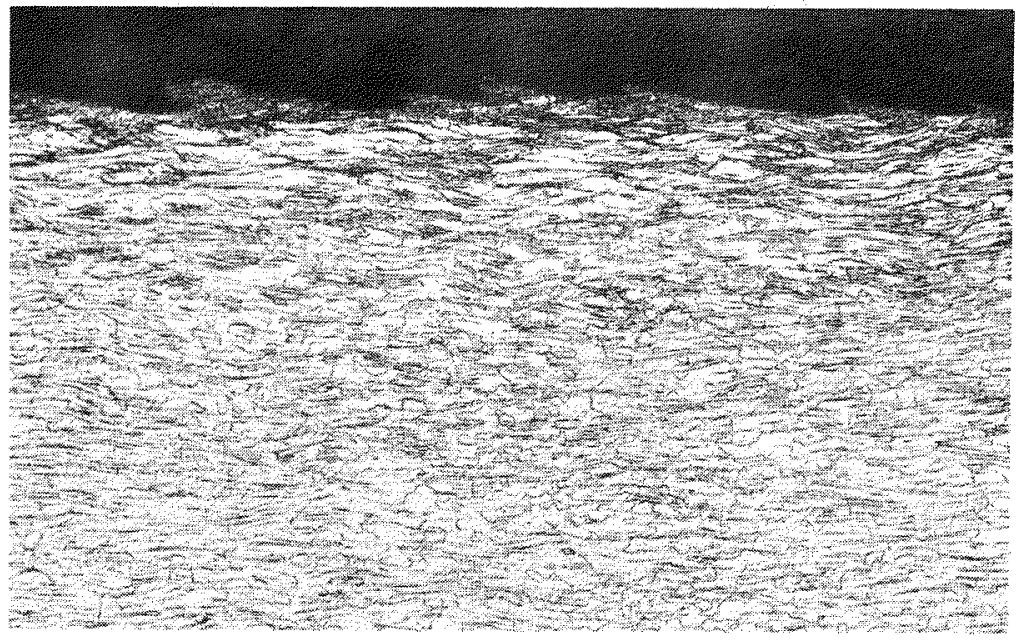

b. Niobium-20 w/o Uranium Alloy

No penetration occurred. Structure is that of heavily worked material. Alloy contained $198 \mathrm{ppm}$ oxygen. Total weight gain was $0.10 \mathrm{mg}$ per $\mathrm{cm}^{2}$.

FIGURE 26. NIOBIUM-10 AND -20 w/O URANIUM ALLOYS EXPOSED TO SODIUM AT 1500 F FOR $1500 \mathrm{HR}$ 


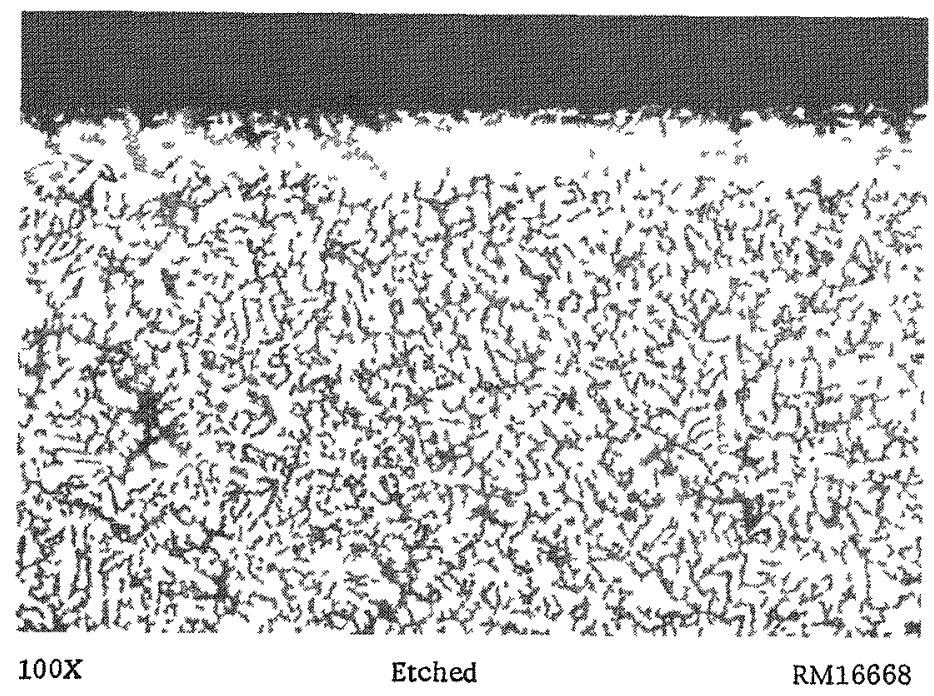

a. Extensive Dendritic Structure and Oxygen-Affected Zone at the Surface

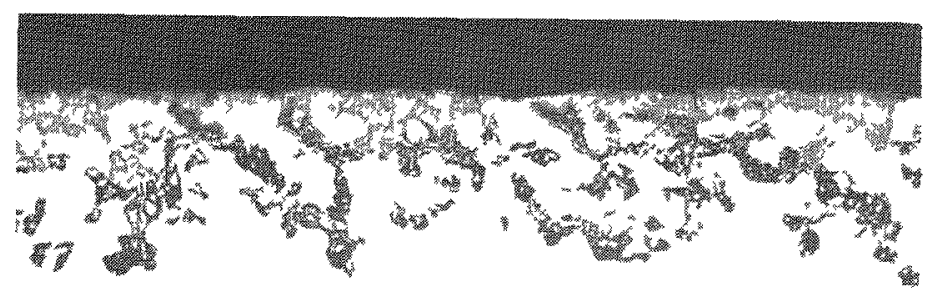

is

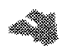

品

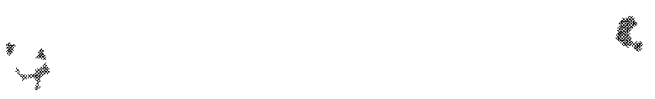

$250 X$

As Pollshed

RM17451

b. Evidence of Internal Oxidation

FIGURE 27. NIOBIUM-60 W/O URANIUM ALLOY EXPOSED TO SODIUM AT 1500 F FOR $1500 \mathrm{HR}$

Material was in the as-cast condition. Alloys contained 192 ppm oxygen prior to testing. 
TABLE 14. PRECORROSION CHEMICAL ANALYSIS OF NIOBIUM-URANIUM SPECIMENS

\begin{tabular}{|c|c|c|c|c|c|c|c|c|c|}
\hline \multirow{2}{*}{$\begin{array}{c}\text { Alloy Composition, } \\
\text { (Balance Niobium), } \\
\text { w/o }\end{array}$} & \multicolumn{4}{|c|}{ Impurity Content of Niobium Melting Stock, ppm } & \multirow[b]{2}{*}{ Condition } & \multicolumn{4}{|c|}{ Analyzed Impurity Content of Alloy Before Exposure, ppm } \\
\hline & Oxygen & Hydrogen & Nitrogen & Carbon & & Oxygen & Hydrogen & Nitrogen & Carbon \\
\hline \multirow[t]{3}{*}{$10 \mathrm{U}$} & 600 & $-\infty$ & 580 & 280 & Fabricated & 680 & 9 & 900 & 340 \\
\hline & 700 & -- & 600 & 270 & Fabricated & 1190 & 3 & 780 & 340 \\
\hline & 300 & -- & 300 & 100 & Fabricated & 3170 & 7 & 780 & 80 \\
\hline \multirow[t]{3}{*}{$20 \mathrm{U}$} & 600 & -- & 580 & 280 & Fabricated & 458 & 7 & 1600 & 370 \\
\hline & 700 & - & 600 & 270 & Fabricated & 523 & 10 & 1000 & 330 \\
\hline & 300 & -- & 300 & 100 & Fabricated & 198 & 19 & 340 & 60 \\
\hline \multirow[t]{3}{*}{$30 \mathrm{U}$} & 600 & -- & 580 & 280 & As cast & 586 & 62 & 850 & 420 \\
\hline & 700 & -- & 600 & 270 & Fabricated & 669 & 12 & 410 & 250 \\
\hline & 300 & -- & 300 & 100 & As cast & 165 & 39 & 120 & 50 \\
\hline \multirow[t]{3}{*}{$40 \mathrm{U}$} & 600 & -- & 580 & 280 & As cast & 661 & 7 & 320 & 310 \\
\hline & 700 & -- & 600 & 270 & As cast & 579 & 2 & 330 & 230 \\
\hline & 300 & -- & 300 & 100 & As cast & 261 & 0.7 & 130 & 20 \\
\hline \multirow[t]{3}{*}{$50 \mathrm{U}$} & 600 & -- & 580 & 280 & As cast & 375 & 7 & 270 & 260 \\
\hline & 700 & -- & 600 & 270 & As cast & 334 & 4 & 260 & 280 \\
\hline & 300 & $-\infty$ & 300 & 100 & As cast & 271 & 2 & 130 & 300 \\
\hline \multirow[t]{3}{*}{$60 \mathrm{U}$} & 600 & - & 580 & 280 & As cast & 471 & 9 & 230 & 190 \\
\hline & 700 & -- & 600 & 270 & As cast & 273 & 3 & 200 & 190 \\
\hline & 300 & - & 300 & 100 & As cast & 192 & 3 & 120 & 80 \\
\hline
\end{tabular}


TABLE 15. CORROSION DATA FOR NIOBIUM-

\begin{tabular}{|c|c|c|c|c|c|c|c|}
\hline \multirow{3}{*}{$\begin{array}{c}\text { Alloy Composition } \\
\text { (Balance Niobium), } \\
\text { w/o }\end{array}$} & \multicolumn{2}{|c|}{ Impurity Content } & \multirow{3}{*}{$\begin{array}{l}\text { Specimen } \\
\text { Condition }\end{array}$} & \multirow[b]{3}{*}{7} & \multirow[b]{3}{*}{28} & \multirow[b]{3}{*}{56} & \multirow[b]{3}{*}{84} \\
\hline & \multirow{2}{*}{$\begin{array}{c}\text { Oxygen }(b), \\
\text { ppm }\end{array}$} & \multirow{2}{*}{$\begin{array}{c}\text { Zirconium } \\
\mathrm{w} / \mathrm{o}\end{array}$} & & & & & \\
\hline & & & & & & & \\
\hline \multirow[t]{3}{*}{$10 \mathrm{U}$} & 680 & 0.74 & Fabricated & 0.12 & 0.28 & 0.40 & 0.62 \\
\hline & 1190 & 0.17 & Fabricated & 0.25 & 0.48 & 0.74 & 1.05 \\
\hline & 3170 & 0.02 & Fabricated & 0.29 & 0.53 & 0.82 & 1.10 \\
\hline \multirow[t]{3}{*}{$20 \mathrm{U}$} & 458 & 0.74 & Fabricated & 0.18 & 0.42 & 0.64 & 1.06 \\
\hline & 523 & 0.17 & Fabricated & 0.25 & 0.49 & 0.78 & 1.08 \\
\hline & 198 & 0.02 & Fabricated & 0.18 & 0.33 & 0.51 & 0.76 \\
\hline \multirow[t]{3}{*}{$30 \mathrm{U}$} & 586 & 0.74 & As cast & 0.31 & 0.53 & 0.78 & 0.94 \\
\hline & 669 & 0.17 & Fabricated & 0.27 & 0.42 & 0.76 & 0.76 \\
\hline & 165 & 0.02 & As cast & 0.31 & 0.64 & 1.03 & 1.43 \\
\hline \multirow[t]{3}{*}{$40 \mathrm{U}$} & 661 & 0.74 & As cast & 0.52 & 0.83 & 1.03 & 0.78 \\
\hline & 579 & 0.17 & As cast & 0.29 & 0.50 & 0.63 & 1.01 \\
\hline & 261 & 0.02 & As cast & 0.23 & 0.40 & 0.61 & 1.04 \\
\hline \multirow[t]{3}{*}{$50 \mathrm{U}$} & 375 & 0.74 & As cast & 0.24 & 0.47 & 0.68 & 0.96 \\
\hline & 334 & 0.17 & As cast & 0.25 & 0.46 & 0.62 & 0.80 \\
\hline & 271 & 0.02 & As cast & 0.26 & 0.46 & 0.55 & 0.95 \\
\hline \multirow[t]{3}{*}{$60 \mathrm{U}$} & 471 & 0.74 & As cast & 0.27 & 0.42 & 0.18 & -0.48 \\
\hline & 273 & 0.17 & As cast & 0.31 & 0.48 & 0.62 & 0.50 \\
\hline & 192 & 0.02 & As cast & 0.20 & 0.36 & 0.46 & 0.58 \\
\hline $100 \mathrm{Nb}$ & 131 & 0.05 & Fabricated & $\cdots$ & -- & - & 0.53 \\
\hline Zircaloy-2 & -- & -. & Fabricated & 0.09 & 0.12 & 0.14 & 0.16 \\
\hline
\end{tabular}

(a) Average of duplicate specimens.

(b) Analyzed value.

(c) Nominal composition. 
URANIUM ALLOYS(a) IN WATER AT $600 \mathrm{~F}$

\begin{tabular}{|c|c|c|c|c|c|c|c|c|}
\hline 112 & 140 & 168 & 196 & 224 & 252 & 280 & 308 & 336 \\
\hline 0.70 & 0.61 & 0.60 & 0.61 & 0.63 & 0.73 & 0.61 & 0.71 & 0.81 \\
\hline 0.90 & 0.60 & -0.59 & -1.12 & -0.76 & -1.23 & -3.45 & -3.92 & -4.56 \\
\hline 0.62 & 0.38 & -1.52 & -2.20 & -3.51 & -3.93 & -5.03 & -5.46 & -6.03 \\
\hline 1.20 & 1.14 & 0.98 & 0.96 & 0.95 & 0.93 & 0.92 & 1.05 & 1.14 \\
\hline 1.34 & 1.35 & 1.64 & 1.90 & 1.93 & 2.33 & 1.99 & 1.32 & 0.82 \\
\hline 0.84 & 0.71 & 0.69 & 0.73 & 0.76 & 0.76 & 0.73 & 0.80 & 0.86 \\
\hline 0.87 & 0.74 & 0.53 & 0.15 & 0.10 & -0.11 & -0.41 & -0.40 & -0.63 \\
\hline 0.54 & -0.25 & -1.28 & -2.15 & -2.32 & -2.75 & -2.78 & -2.79 & -2.78 \\
\hline 1.02 & 1.07 & 0.40 & -0.78 & -0.59 & -0.86 & -1.61 & -1.30 & -1.25 \\
\hline 0.75 & 0.49 & 0.49 & 0.43 & 0.43 & 0.63 & 0.63 & 0.40 & 0.20 \\
\hline 0.75 & 0.47 & 0.28 & 0.20 & 0.20 & 0.23 & 0.03 & 0.07 & 0.18 \\
\hline 0.89 & 0.77 & 0.57 & 0.61 & 0.62 & 0.75 & 0.53 & 0.67 & 0.96 \\
\hline 1.00 & 0.87 & 0.61 & 0.31 & 0.15 & -0.17 & -0.53 & -0.77 & -1.16 \\
\hline 0.92 & 0.66 & 0.53 & 0.40 & 0.37 & 0.24 & -0.06 & -0.07 & -0.11 \\
\hline 0.59 & 0.38 & 0.04 & -0.31 & -0.54 & -0.88 & -1.45 & -1.82 & $-2,62$ \\
\hline-1.21 & -2.12 & -3.28 & -4.70 & -6.02 & -7.53 & -8.76 & -10.63 & -12.60 \\
\hline 0.03 & -1.32 & -2.80 & -4.23 & -5.44 & -6.47 & -7.34 & -8.16 & -9.50 \\
\hline-0.38 & -0.18 & -0.76 & -1.27 & -1.67 & -2.16 & -2.78 & -3.67 & $-\infty$ \\
\hline 0.63 & 0.67 & 0.75 & 0.79 & 0.73 & 0.89 & 0.76 & 0.70 & - \\
\hline 0.20 & 0.22 & $\cdots$ & $m$ & 0.24 & 0.26 & 0.28 & 0.32 & $\ldots$ \\
\hline
\end{tabular}




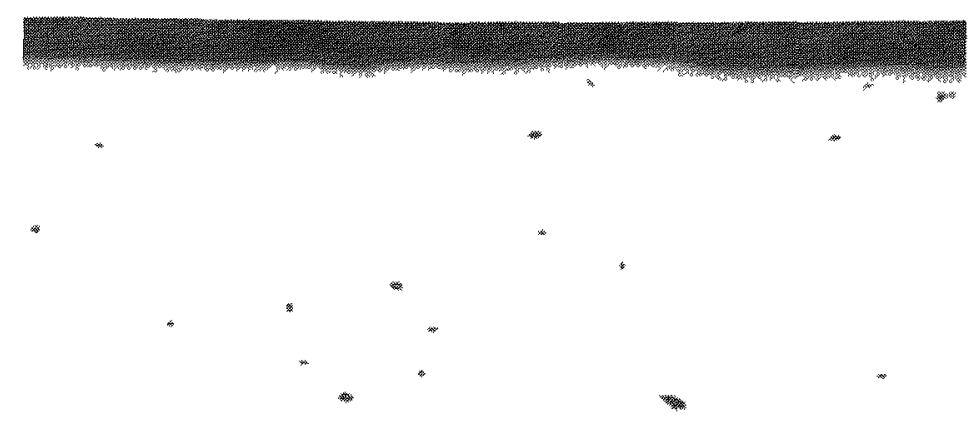

$250 \mathrm{X}$

a. As Polished

RM17452

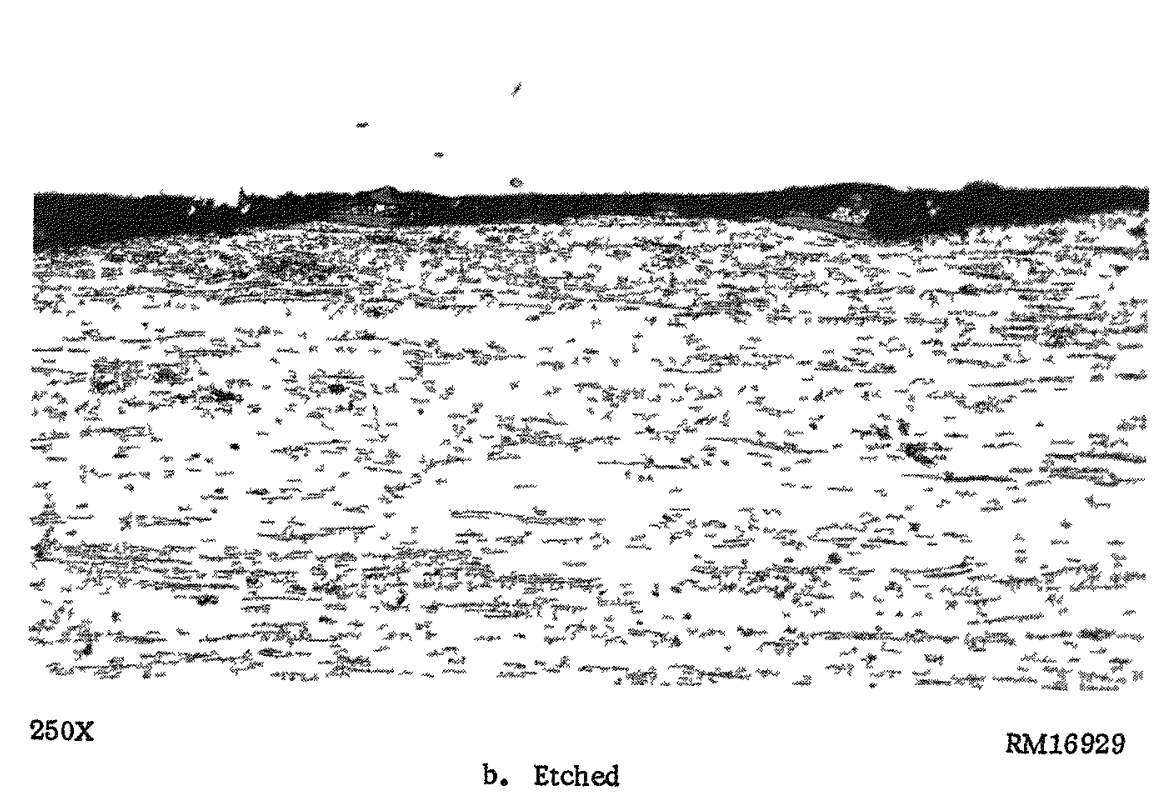

FIGURE 28. NIOBIUM-10 W/O URANIUM ALLOY EXPOSED TO 600 F WATER FOR 336 DAYS

No oxide penetration into the structure is apparent. Specimen showed a total weight gain of $0.81 \mathrm{mg}$ per $\mathrm{cm}^{2}$. Slight surface oxide is visible. 


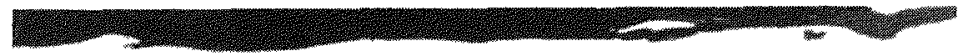

a. As Polished

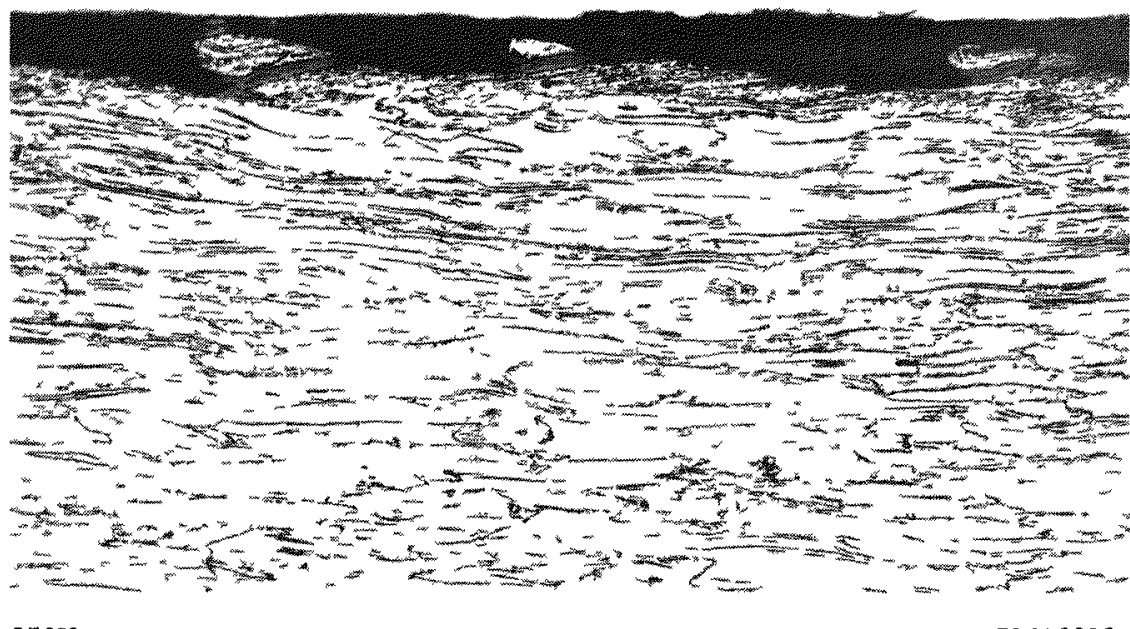

$250 \mathrm{X}$

b. Etched

RM16928

FIGURE 29. NIOBIUM-20 W/O URANIUM ALLOY EXPOSED TO $600 \mathrm{~F}$ WATER FOR 336 DAYS

No oxide penetration into structure is apparent. Specimen showed a total weight gain of $86 \mathrm{mg}$ per $\mathrm{cm}^{2}$. Slight surface oxide is visible. 


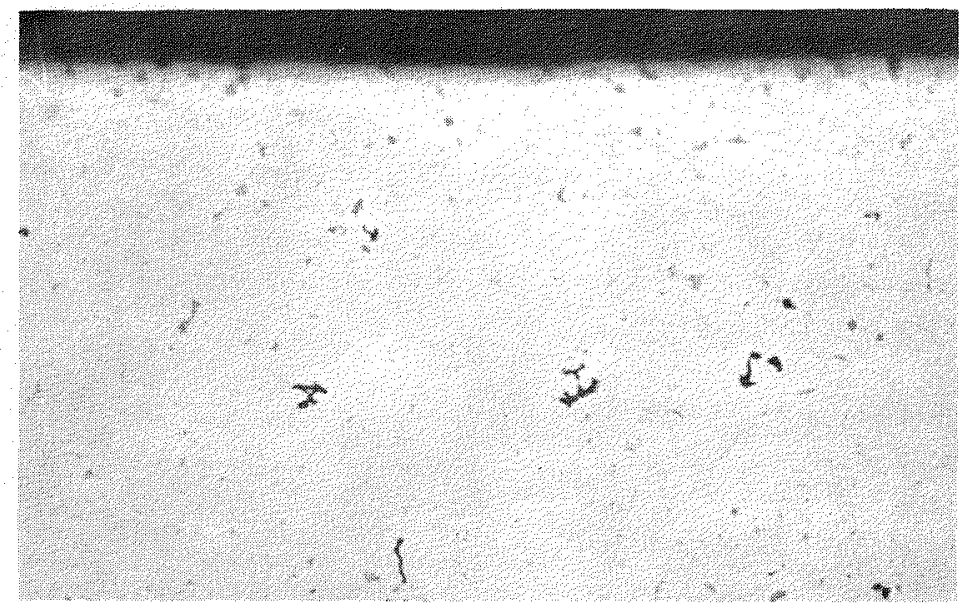

$250 \mathrm{X}$

RM17449

a. As Polished

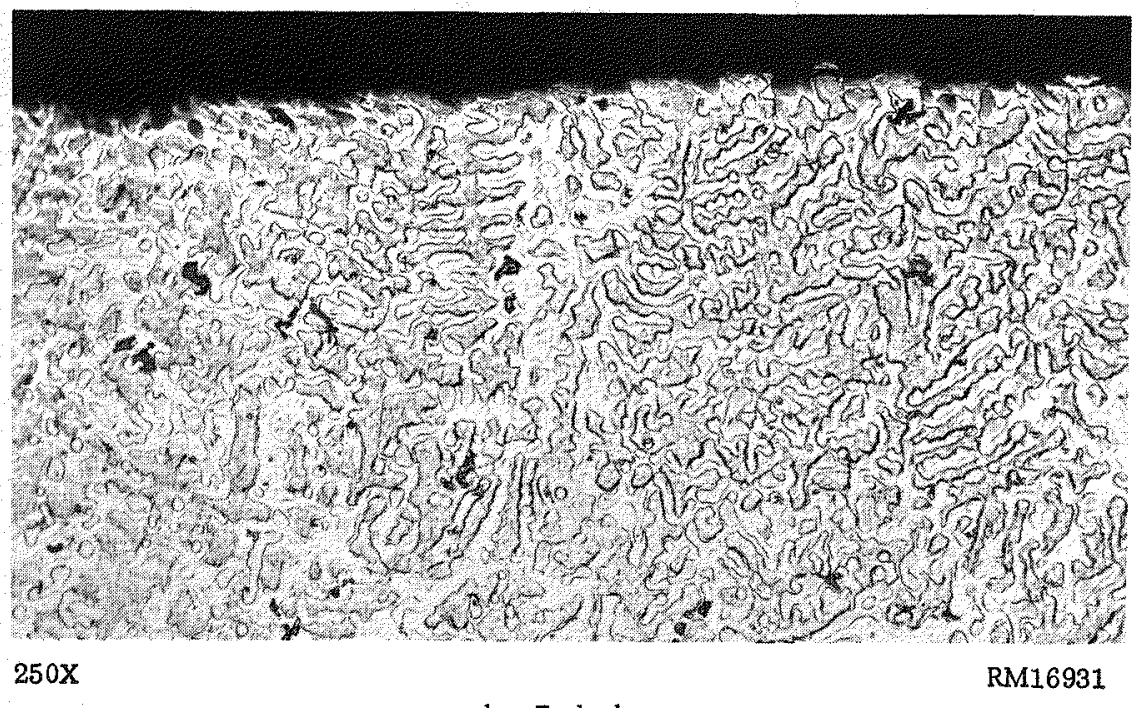

b. Etched

FIGURE 30. NIOBIUM-50 W/O URANIUM ALLOY EXPOSED TO $600 \mathrm{E}$ WATER FOR 336 DAYS

No oxide penetration into structure is apparent. Specimen showed a total weight loss of $0.11 \mathrm{mg}$ per $\mathrm{cm}^{2}$. Structure is as cast and shows dendrites. 
The surfaces of niobium-10, -20 , and $-50 \mathrm{w} / 0$ uranium specimens are shown in Figures 28, 29, and 30, respectively, in both the as-polished and etched condition. These micrographs show a slight oxide film but no apparent penetration. The niobium-10 and $-20 \mathrm{w} / 0$ uranium alloys were tested in a cold-worked condition while the niobium-50 $\mathrm{w} / \mathrm{o}$ uranium alloy was in the as-cast condition. The structure of the $50 \mathrm{w} / \mathrm{o}$ uranium alloy, Figure 30, shows dendrites formed during solidification.

As would be expected, more extensive attack by water (Table 16) was observed at $680 \mathrm{~F}$. After 140 days' exposure, almost all of the alloys showed weight losses. In order to determine if there was any correlation between hydrogen pickup and corrosion, samples of each alloy were analyzed for hydrogen. Table 17 lists the changes in hydrogen content and total weight gain of hydrogen. Evaluation of data shown in this table indicates that in the high-niobium alloys (niobium-10, -20 , and $-30 \mathrm{w} / \mathrm{o}$ uranium), excessive weight losses are accompanied by large increases in hydrogen content; however, in the remaining alloys (niobium $-40,-50$, and $-60 \mathrm{w} / 0$ uranium) the weight loss does not appear to be related to hydrogen pickup. The corrosion mechanism for the niobiumuranium alloys probably changes with increasing uranium content with the role of hydrogen in corrosion becoming negligible in the higher uranium alloys.

The microstructure of the niobium-10 w/o uranium alloy which lost $1.66 \mathrm{mg}$ per $\mathrm{cm}^{2}$ after 140 days' exposure is shown in Figure 31. An oxide layer can be observed on the surface.

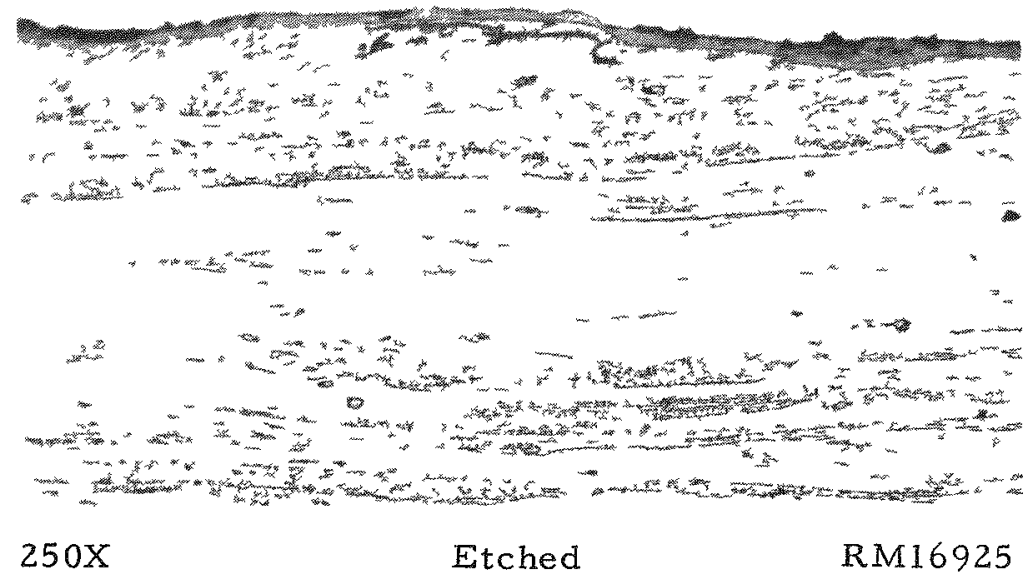

FIGURE 31. NIOBIUM-10 w/O URANIUM ALLOY EXPOSED TO 680 F WATER FOR 140 DAYS

Continuous surface oxide is visible. Specimen showed a weight loss of $1.66 \mathrm{mg}$ per $\mathrm{cm}^{2}$.

The niobium-20 w/o uranium alloy appears to possess the best corrosion resistance in both 600 and $680 \mathrm{~F}$ water of the niobium-uranium alloys tested. Figure 32 shows a plot of the corrosion behavior of this alloy in 600 and $680 \mathrm{~F}$ water as compared with that of Zircaloy-2 in $680 \mathrm{~F}$ water. In $600 \mathrm{~F}$ water the alloy shows a slight weight increase which levels off quickly; very little change in weight is noted up to 336 days after the initial increase. In $680 \mathrm{~F}$ water, the niobium-20 w/o uranium alloy shows a steady 
TABLE 16. CORROSION DATA FOR NIOBIUM-

\begin{tabular}{|c|c|c|c|c|c|}
\hline \multirow{3}{*}{$\begin{array}{c}\text { Alloy Composition } \\
\text { (Balance Niobium), } \\
\text { w/o }\end{array}$} & \multicolumn{2}{|c|}{ Impurity Content } & \multirow{3}{*}{$\begin{array}{l}\text { Specimen } \\
\text { Condition }\end{array}$} & \multirow[b]{3}{*}{7} & \multirow[b]{3}{*}{14} \\
\hline & \multirow{2}{*}{$\begin{array}{c}\text { Oxygen }(b), \\
\text { ppm }\end{array}$} & \multirow{2}{*}{$\begin{array}{c}\operatorname{Zirconium}(c), \\
\text { w/o }\end{array}$} & & & \\
\hline & & & & & \\
\hline \multirow[t]{3}{*}{$10 \mathrm{U}$} & 680 & 0.74 & Fabricated & 0.28 & 0.32 \\
\hline & 1190 & 0.17 & Fabricated & 0.09 & -1.52 \\
\hline & 3170 & 0.02 & Fabricated & -4.22 & -14.3 \\
\hline \multirow[t]{3}{*}{$20 \mathrm{U}$} & 458 & 0.74 & Fabricated & 0.30 & 0.48 \\
\hline & 523 & 0.17 & Fabricated & 0.43 & 0.68 \\
\hline & 198 & 0.02 & Fabricated & 0.22 & 0.38 \\
\hline \multirow[t]{3}{*}{$30 \mathrm{U}$} & 586 & 0.74 & As cast & 1.00 & 1.19 \\
\hline & 669 & 0.17 & Fabricated & 0.97 & 0.88 \\
\hline & 165 & 0.02 & As cast & 0.50 & 0.70 \\
\hline \multirow[t]{3}{*}{$40 \mathrm{U}$} & 661 & 0.74 & As cast & 0.66 & 0.75 \\
\hline & 579 & 0.17 & As cast & 0.46 & 0.43 \\
\hline & 261 & 0.02 & As cast & 0.46 & 0.65 \\
\hline \multirow[t]{3}{*}{$50 \mathrm{U}$} & 375 & 0.74 & As cast & 0.83 & 0.47 \\
\hline & 334 & 0.17 & As cast & 0.44 & 0.39 \\
\hline & 271 & 0.02 & As cast & 0.38 & 0.27 \\
\hline \multirow[t]{3}{*}{$60 \mathrm{U}$} & 471 & 0.74 & As cast & 1.86 & -24.0 \\
\hline & 273 & 0.17 & As cast & 0.57 & -0.26 \\
\hline & 192 & 0.02 & As cast & 0.31 & $=0.02$ \\
\hline \multirow[t]{2}{*}{$100 \mathrm{Nb}$} & 131 & 0.05 & Fabricated & -- & 0.79 \\
\hline & 500 & 0.03 & Fabricated & -- & 0.41 \\
\hline Zircaloy-2 & -- & -- & Fabricated & -- & 0.15 \\
\hline
\end{tabular}

(a) Average of duplicate specimens.

(b) Analyzed values.

(c) Nominal compositions.

(d) Both specimens taken off tests.

(e) Completely oxidized after 56 days of exposure. 
URANIUM ALLOYS $^{(a)}$ IN 680 F WATER

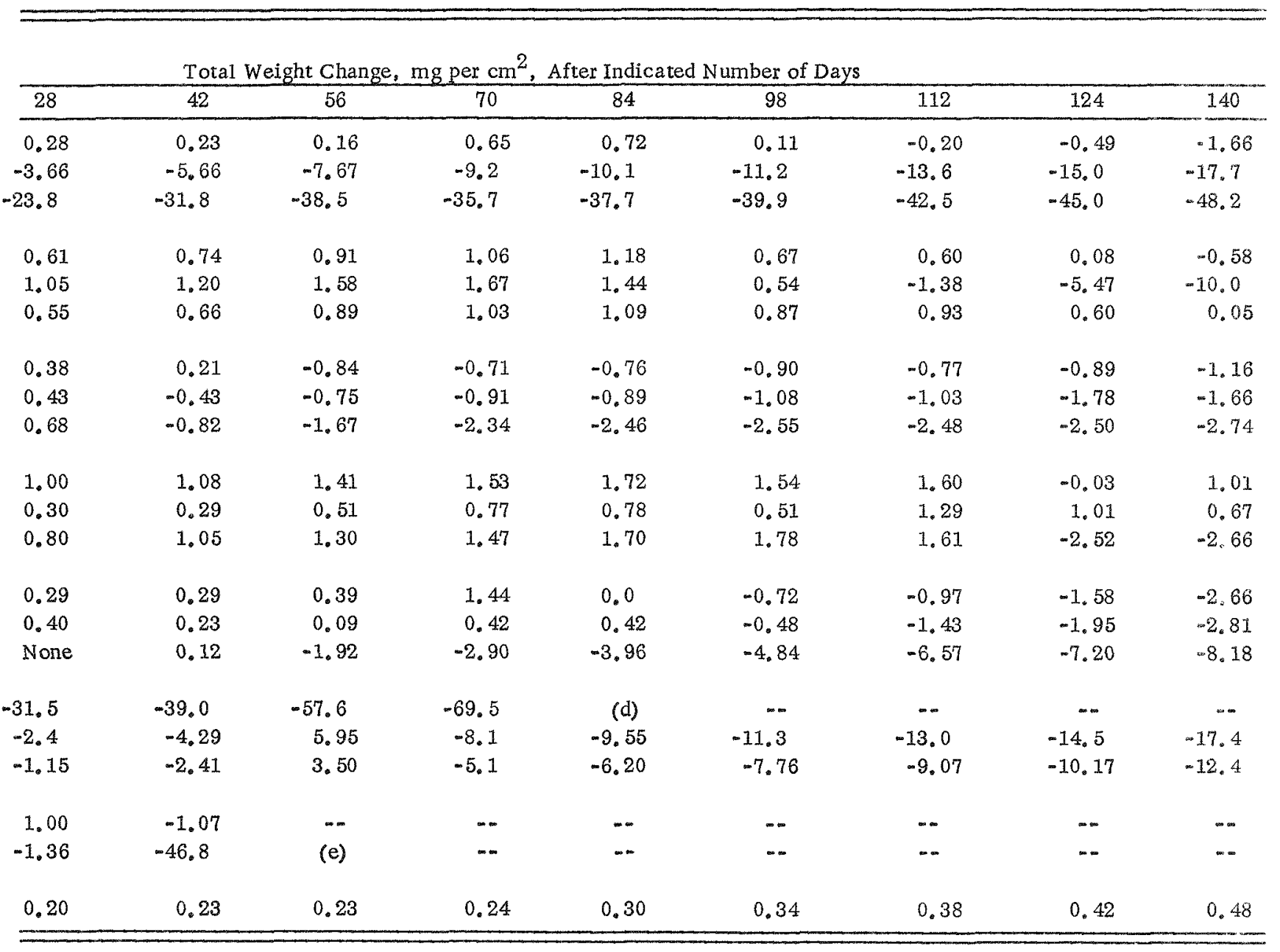


TABLE 17. RESULTS OF ANALYSES (a) FOR HYDROGEN CONTENT OF NIOBIUM-URANIUM ALLOYS AFTER 140 DAYS IN $680 \mathrm{~F}$ WATER

\begin{tabular}{|c|c|c|c|c|c|}
\hline $\begin{array}{c}\text { Alloy } \\
\text { Composition } \\
\text { (Balance Niobium), } \\
\text { w/o }\end{array}$ & $\begin{array}{l}\text { Analyzed } \\
\text { Oxygen } \\
\text { Content, } \\
\text { ppm }\end{array}$ & $\begin{array}{l}\text { Hydrogen } \\
\text { Before } \\
\text { Exposure }\end{array}$ & $\frac{\text { Content, ppm }}{\text { After }}$ & $\begin{array}{l}\text { Total Weight } \\
\text { Gain of } \\
\text { Hydrogen, } \\
\text { mg per } \mathrm{cm}^{2}\end{array}$ & $\begin{array}{c}\text { Total Weight } \\
\text { Change, } \\
\text { mg per } \mathrm{cm}^{2}\end{array}$ \\
\hline \multirow[t]{3}{*}{$10 \mathrm{U}$} & 680 & 9 & 155 & 0.011 & -1.66 \\
\hline & 1190 & 3 & 870 & 0.27 & -17.7 \\
\hline & 3170 & 7 & 1510 & 0.51 & -48.2 \\
\hline \multirow[t]{3}{*}{$20 \mathrm{U}$} & 458 & 7 & 89 & 0.028 & -0.58 \\
\hline & 523 & 10 & 790 & 0.415 & -10.0 \\
\hline & 198 & 19 & 47 & 0.026 & 0.05 \\
\hline \multirow[t]{3}{*}{$30 \mathrm{U}$} & 586 & 62 & 127 & 0.011 & -1.16 \\
\hline & 669 & 12 & 66 & 0.054 & -1.66 \\
\hline & 165 & 39 & 21 & -0.028 & -2.74 \\
\hline \multirow[t]{3}{*}{$40 \mathrm{U}$} & 661 & 7 & 52 & 0.038 & 1.01 \\
\hline & 579 & 2 & 46 & 0.038 & 0.67 \\
\hline & 261 & 0.7 & 10 & 0.009 & -2.66 \\
\hline \multirow[t]{3}{*}{$50 \mathrm{U}$} & 375 & 7 & 28 & 0.02 & -2.66 \\
\hline & 334 & 4 & 16 & 0.017 & -2.81 \\
\hline & 271 & 2 & 23 & 0.017 & -8.18 \\
\hline \multirow[t]{3}{*}{$60 \mathrm{U}$} & 471 & 9 & (c) & -- & (c) \\
\hline & 273 & 3 & 66 & 0.05 & -17.4 \\
\hline & 192 & 3 & 35 & 0.02 & -12.4 \\
\hline
\end{tabular}

(a) Vacuum-fusion method.

(b) Performed on unabraded surfaces.

(c) Specimens lost in tests after 70 days. 


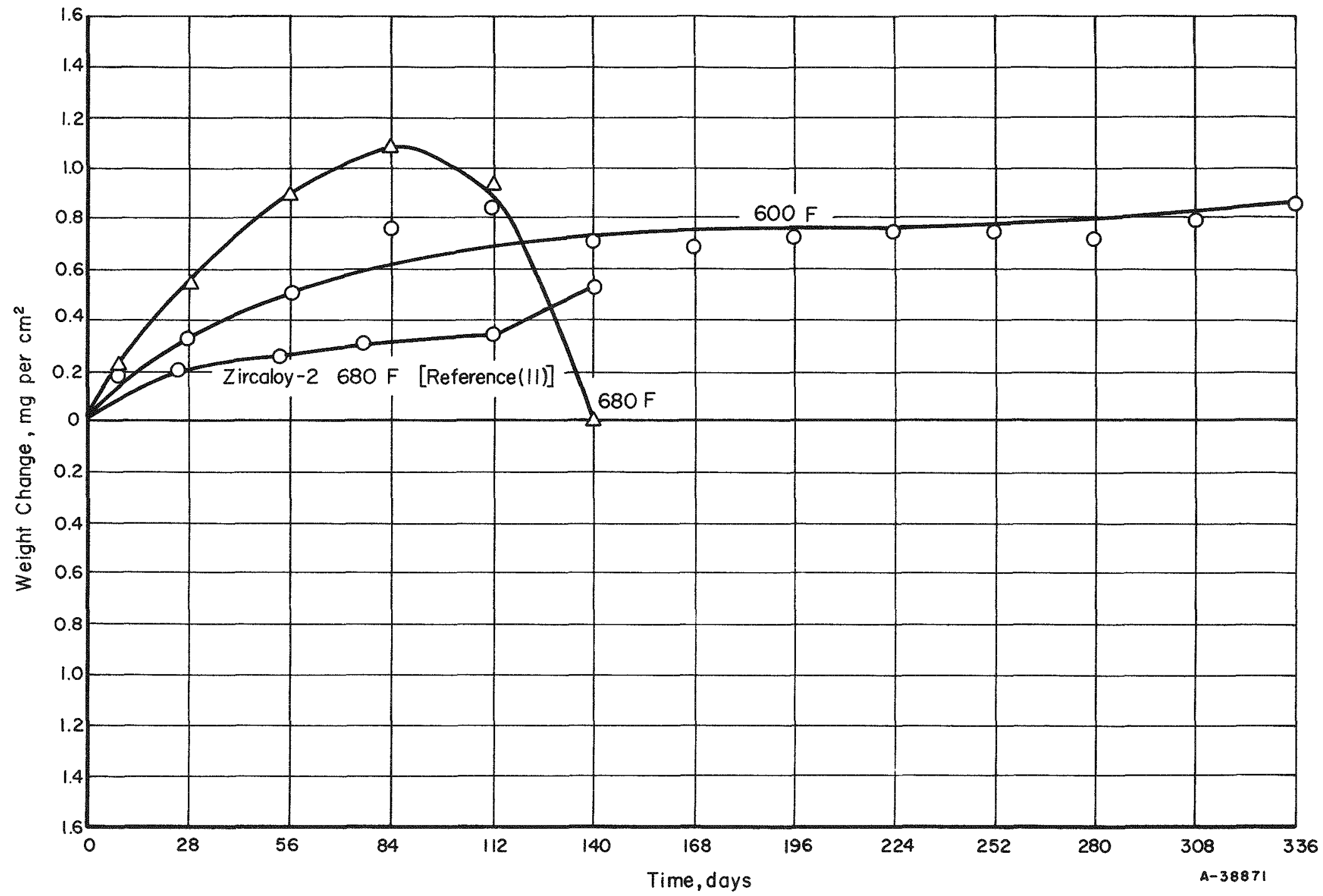

FIGURE 32. EFFECT OF TIME ON WEIGHT CHANGES OF NIOBIUM-20 w/O URANIUM ALLOY IN 600 AND $680 \mathrm{~F}$ WATER 
increase in weight up to 84 days, at which time the alloy begins to lose weight. At this point, the oxide layer has ceased to be adherent and begins to spall. It continued to spall for the remaining time to 140 days' exposure at which point the specimen was removed from test.

All of the niobium-uranium alloys tested appear to possess adequate corrosion resistance to 600 and $680 \mathrm{~F}$ water so that defects in cladding which might occur would not be serious for relatively long periods of time.

\section{PHYSICAL-PROPERTY DETERMINATIONS}

Thermal-Conductivity Measurements

Thermal-conductivity measurements were made by a steady-heat-flow method which consists of heating one end of a specimen, measuring the temperature gradient along the specimen, and determining the rate of heat flow through the specimen by means of a metal standard (Armco iron) of known thermal conductivity attached to the cold end of the specimen. Radial heat flow into or away from the specimen is kept to a minimum by thermal insulation and an encircling guard tube. Tests were performed under a vacuum of approximately $2 \times 10^{-5} \mathrm{~mm}$ of mercury. Five Chromel-Alumel thermocouples in the niobium $-20 \mathrm{w} / 0$ uranium alloy specimen and four in the niobium-10 w/o uranium alloy specimen were wedged in equally spaced holes along the specimen. Two thermocouples were also placed in the Armco iron standard.

Figure 33 shows the thermal conductivity of unalloyed niobium and the niobium-10 and $-20 \mathrm{w} / 0$ uranium alloys from room temperature to $1800 \mathrm{~F}$. Alloying uranium with niobium results in decreased thermal conductivity. This effect is more pronounced at room temperature than at elevated temperatures.

\section{Electrical-Resistivity Measurements}

Electrical-resistivity measurements were made on the niobium-10 and $-20 \mathrm{w} / 0$ uranium alloys by the potentiometric method using a specimen approximately 1 in. long. Steel points pressed against the specimen were used as potential leads; copper wires clamped to the ends of the specimens served as current leads. Measurements were made under a vacuum of about $5 \times 10^{-5} \mathrm{~mm}$ of mercury. Results of resistivity measurements are shown in Figure 34. As can be seen, the addition of uranium to niobium significantly increases the resistivity of unalloyed niobium.

Since the thermal conductivity and electrical conductivity (reciprocal of electrical resistivity) of a metal depend upon the presence of free electrons, there should be a relatively simple relationship between the two. Wiedemann and Franz $(12)$ proposed that the ratio $K / \sigma$, where $K$ is the thermal conductivity and $\sigma$ is the electrical conductivity, should be constant. Lorenz later showed the above relationship to be temperature dependent and introduced $\mathrm{T}$, the absolute temperature, to yield the constant $\mathrm{K} / \sigma \mathrm{T}$. Later 


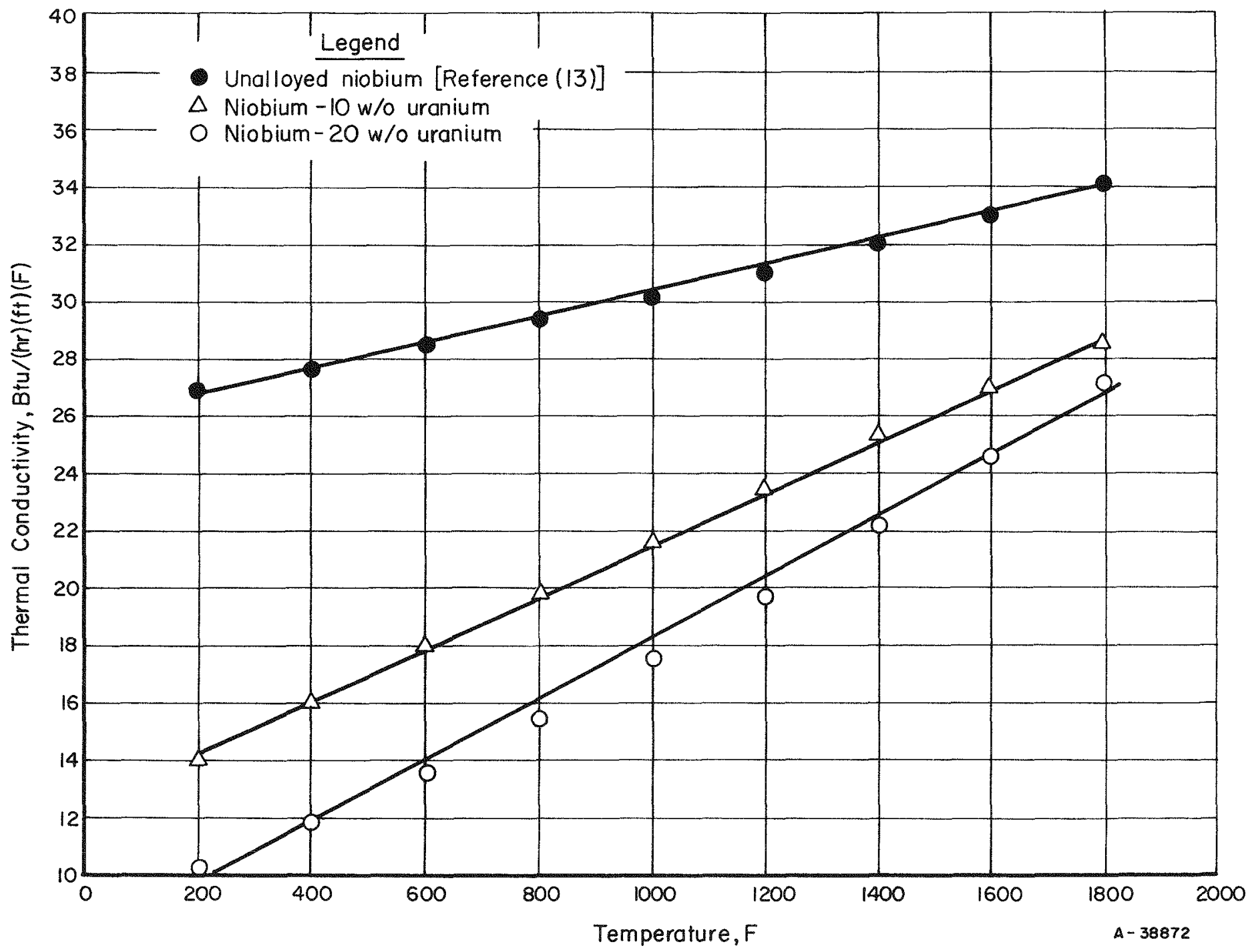

FIGURE 33. THERMAL CONDUCTIVITY OF NIOBIUM AND NIOBIUM-10 AND - 20 w/O URANIUM ALLOYS 


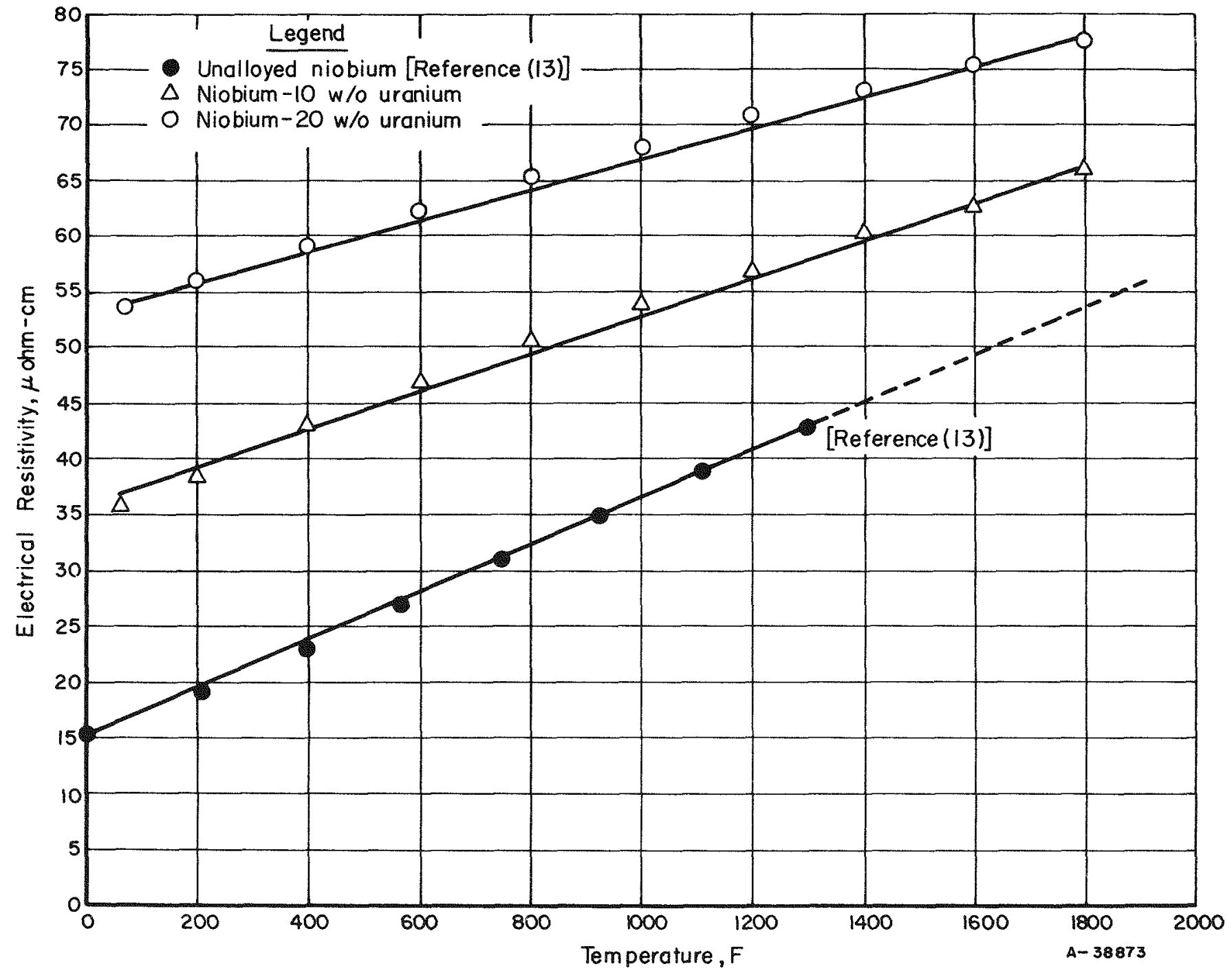

FIGURE 34. ELECTRICAL RESISTIVITY OF NIOBIUM AND NIOBIUM-10 AND - 20 w/o URANIUM ALLOYS 
work has shown that closer correlation between electrical and thermal conductivity can be obtained by adopting an equation of the form

$$
K=A \sigma T+B
$$

where the constants $A$ and $B$ are determined empirically. In the above equation, the term $A \sigma T$ is considered the contribution of electronic conduction and $B$ is the contribution of lattice conduction to the total thermal conductivity. The usefulness of this equation lies in the ability to predict the thermal conductivity of a given alloy if the electrical conductivity of the alloy is known. In Figure 35 a plot is shown of the Wiedemann-Franz relation for niobium-uranium alloys. This curve was obtained by plotting the thermal conductivity versus the $\sigma \mathrm{T}$ where $\mathrm{T}$ is the temperature in degrees Kelvin. A least-square analysis of the data shown in Figures 33 and 34 yielded the equation $K=0.0124+(0.0271)$ $\sigma \mathrm{T}$ as the best fit for the niobium-uranium system. As can be seen in Figure 35, the experimental curve also shows a reasonably good fit with the so-called "ideal" Wiedmann-Franz relation $(K=0.0245 \sigma \mathrm{T})$.

\section{Thermal-Expansion Measurements}

Linear-thermal-expansion measurements shown in Figure 36 were made in a vertical quartz-tube recording dilatometer. Each specimen was thermal cycled twice from room temperature to about $1800 \mathrm{C}$ and back to room temperature. Tests were performed in a vacuum of at least $5 \times 10^{-5} \mathrm{~mm}$ of mercury. Alloying with 10 and $20 \mathrm{w} / 0$ uranium does not appear to significantly affect the thermal expansion of niobium.

\section{Recrystallization Studies}

The recrystallization behavior of the niobium-4.38, -10,-14.3,-20,-25, and $-30 \mathrm{w} / \mathrm{O}$ uranium alloys was investigated. All alloys with the exception of the $30 \mathrm{w} / \mathrm{o}$ uranium alloy were reduced 90 per cent by rolling; the $30 \mathrm{w} / 0$ uranium alloy could only be reduced 80 per cent. Hardness measurements were obtained to serve as a rough indication of recrystallization with the extent of recrystallization being finally determined by metallographic examination.

Specimens of each alloy were annealed for $1 \mathrm{hr}$ between 1800 and 2600 at $100 \mathrm{~F}$ intervals. Hardness measurements showed a large drop from room temperature to $1800 \mathrm{~F}$ (the lowest annealing temperature) with no additional decrease in hardness apparent upon increasing annealing temperatures to $2600 \mathrm{~F}$. Major stress relief apparently occurs below $1800 \mathrm{~F}$. This has been observed before with niobium-base alloys. (5)

In Figure 37 the microstructure of cold-worked niobium-14.3 w/o uranium is shown. This microstructure is typical of all the cold-worked alloys. A typical recrystal-lized microstructure is shown in Figure 38 for the niobium-30 w/o uranium alloy which was completely recrystallized at $2200 \mathrm{~F}$. Table 18 lists the alloys studied and the temperatures at which recrystallization was completed.

In Figure 39, the microstructure of the niobium-10 w/o uranium alloy is shown. This alloy failed to completely recrystallize even at $3000 \mathrm{~F}$. Recrystallization for this 


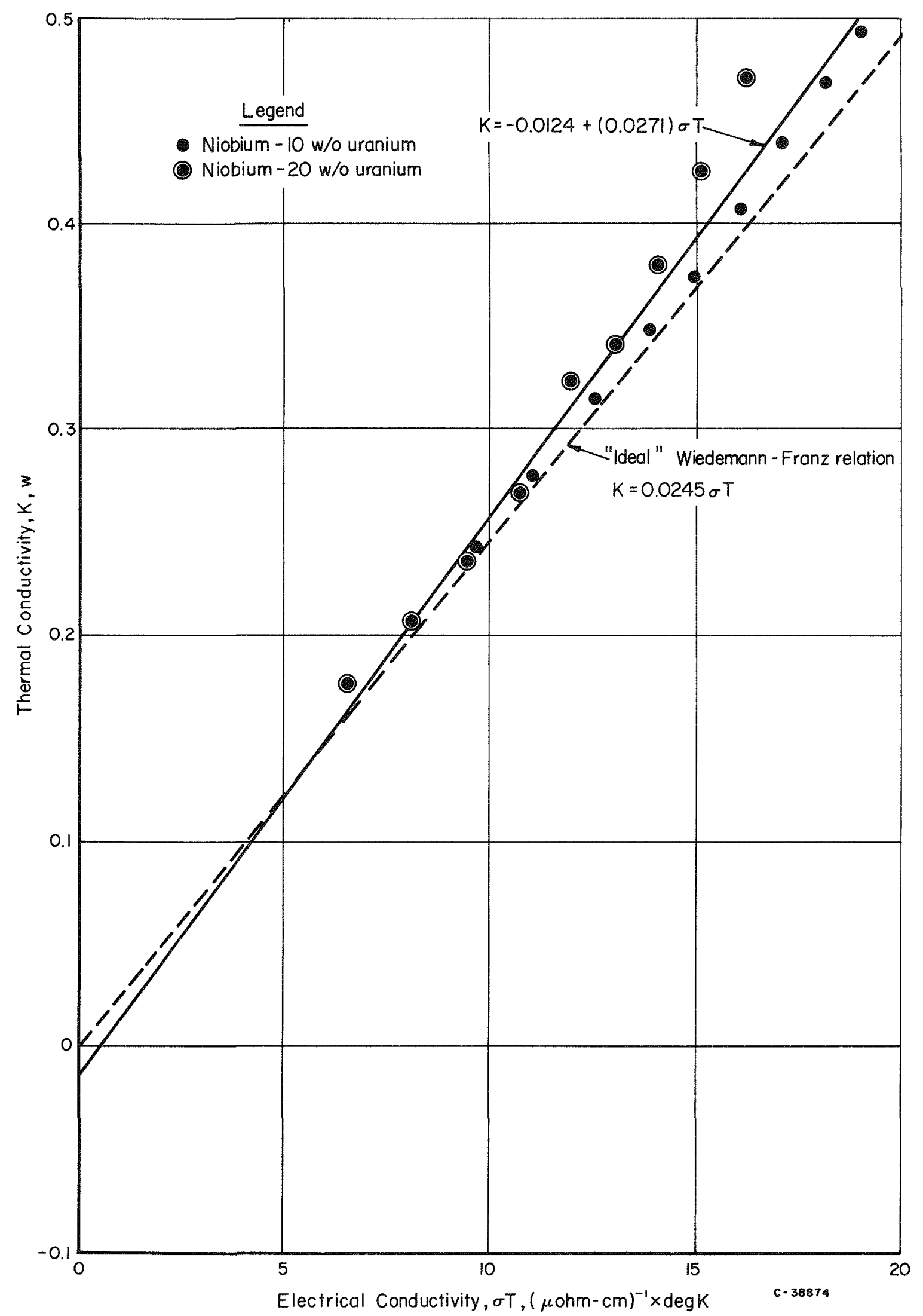

FIGURE 35. THERMAL AND ELECTRICAL CONDUC TIVITY RELATIONSHIPS FOR NIOBIUM-URANIUM ALLOYS 


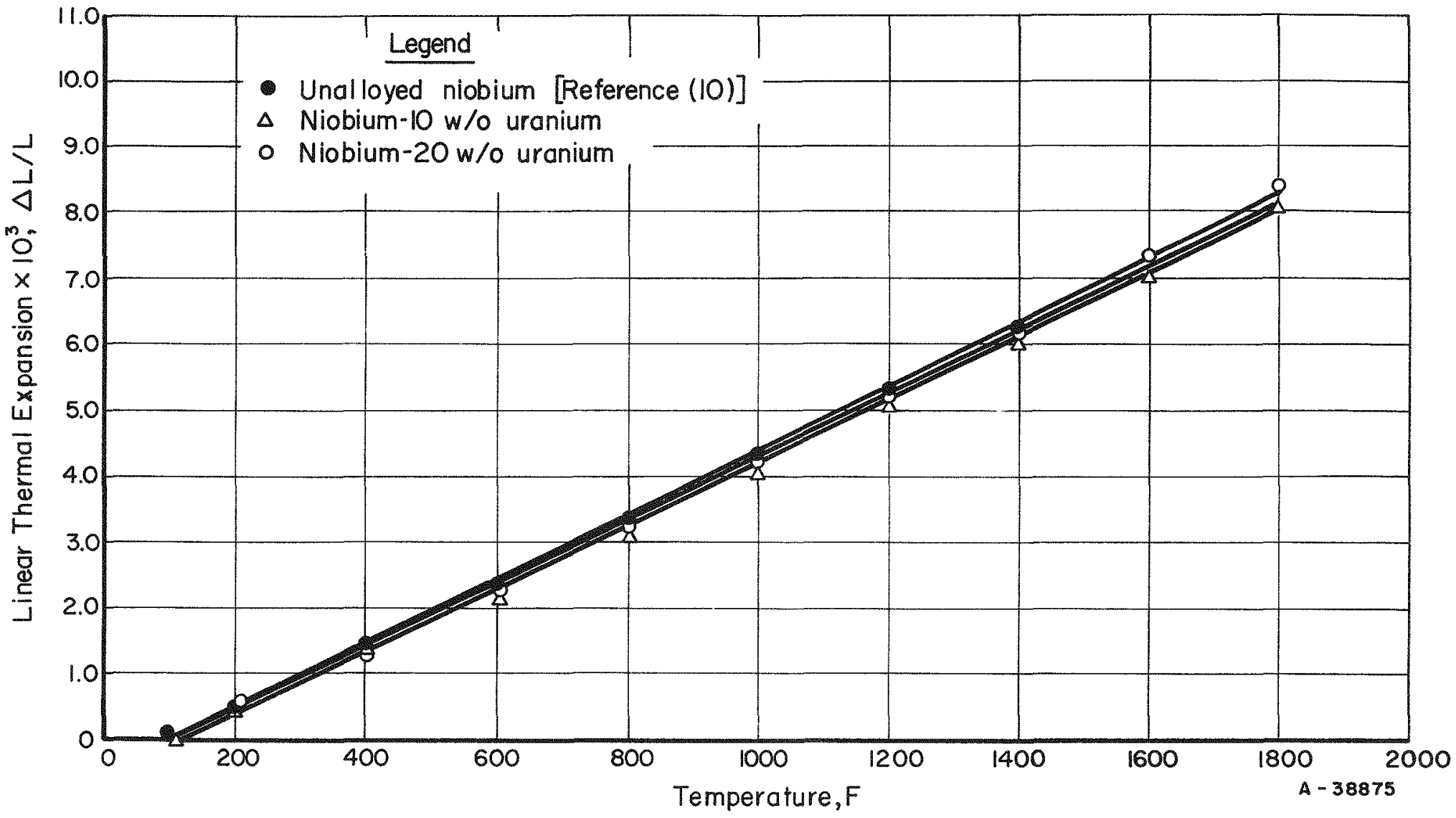

FIGURE 36. LINEAR THERMAL EXPANSION OF NIOBIUM AND NIOBIUM-10 AND -20 w/O URANIUM ALLOYS 

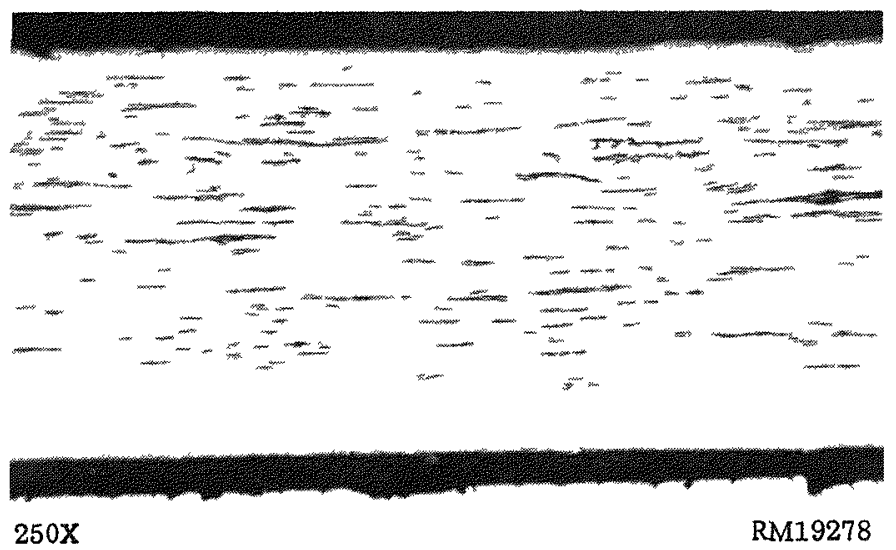

FIGURE 37. NIOBIUM-14.3 w/O URANIUM ALLOY COLD WORKED TO 90 PER CENT REDUCTION IN THICKNESS

This structure is typical of the cold-worked niobiumuranium alloys.

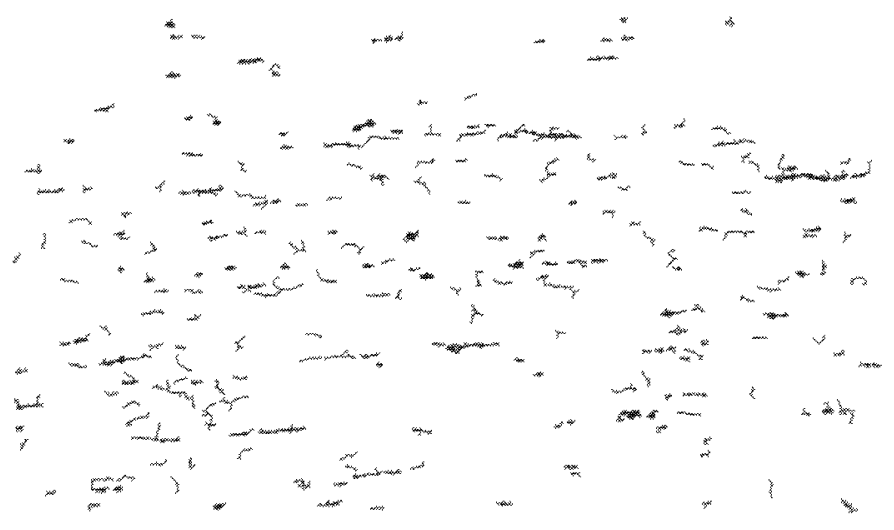

$250 \mathrm{X}$

RM17160

FIGURE 38. NIOBIUM-30 w/o URANIUM ALLOY COLD WORKED TO 80 PER CENT REDUCTION IN THICKNESS AND ANNEALED 1 HR AT $2200 \mathrm{~F}$

Microstructure shows complete recrystallization.

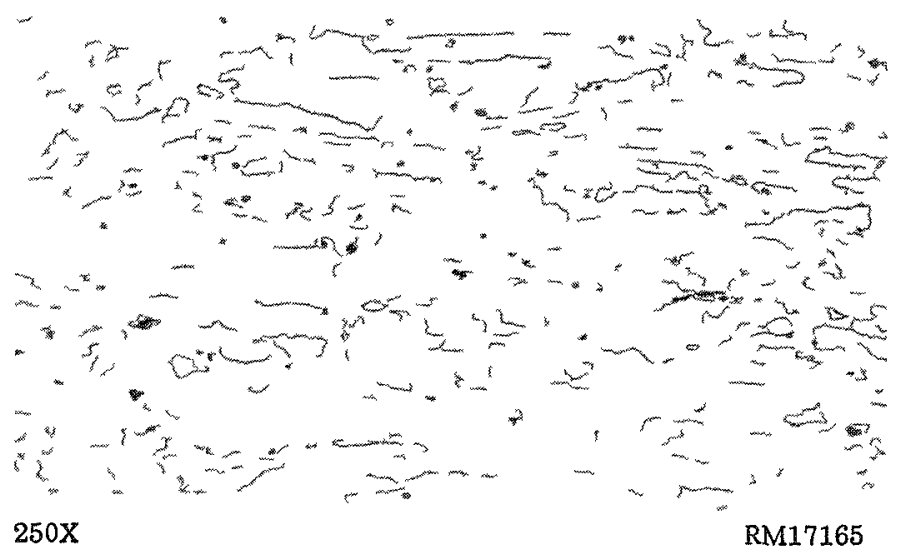

FIGURE 39. NIOBIUM-10 w/O URANIUM ALLOY COLD WORKED TO 90 PER CENT REDUCTION IN THICKNESS AND ANNEALED 1 HR AT $2400 \mathrm{~F}$

High oxygen content ( $3100 \mathrm{ppm})$ of alloy is believed responsible for lack of recrystallization at temperatures to $3000 \mathrm{~F}$. 
TABLE 18. RECRYSTALLIZATION TEMPERATURES OF NIOBIUM-URANIUM ALLOYS

\begin{tabular}{ccc}
\hline $\begin{array}{c}\text { Alloy Composition } \\
\text { (Balance Niobium), } \\
\text { w/o }\end{array}$ & $\begin{array}{c}\text { Cold Work, } \\
\text { per cent }\end{array}$ & $\begin{array}{c}\text { Temperature at } \\
\text { Which Recrystallization } \\
\text { is Complete }\end{array}$ \\
\hline $\begin{array}{l}4.38 \mathrm{U} \\
10 \mathrm{U}\end{array}$ & 90 & $2300 \mathrm{~F}$ \\
$14.3 \mathrm{U}$ & 92 & Did not recrystallize at $3000 \mathrm{~F}^{(\mathrm{a})}$ \\
$20 \mathrm{U}$ & 90 & $2300 \mathrm{~F}$ \\
$25 \mathrm{U}$ & 92 & $2400 \mathrm{~F}$ \\
$30 \mathrm{U}$ & 90 & $2300 \mathrm{~F}$ \\
& 80 & $2200 \mathrm{~F}$ \\
\hline
\end{tabular}

(a) Alloy contained $3100 \mathrm{ppm}$ oxygen.

alloy would be expected around $2300 \mathrm{~F}$. Consequently, it appears that the high oxygen content of the alloy ( $3100 \mathrm{ppm})$ is preventing recrystallization with stress relief occurring before recrystallization can occur.

Uranium composition appears to have little effect on the recrystallization temperature in the range of compositions studied.

\section{PHASE STUDIES}

The effects of oxygen and zirconium on the composition limits of the gamma immiscibility loop in the niobium-uranium alloy system were also investigated. It is desirable to know the effects of oxygen and zirconium on niobium-uranium alloy structures since oxygen is a major impurity and zirconium a desirable alloying addition to niobiumuranium alloys. It was planned to compare the results obtained in this study with the composition limits of the gamma immiscibility loop determined from diffusion couples in a previous study. The two-phase region was established in this previous study on the basis of concentration-penetration curves determined by electron-microprobe analyses of the diffusion-annealed couples, as extending between 9 and 55 w/o niobium at $700 \mathrm{C}$, between 17 and $42 \mathrm{w} / 0$ niobium at $900 \mathrm{C}$, and between 21 and $37 \mathrm{w} / \mathrm{o}$ niobium at $925 \mathrm{C}$. At $1000 \mathrm{C}$, no two-phase immiscibility loop was detected in the diffusion couples.

In order to study the effects of oxygen on the gamma immiscibility loop, measured amounts of oxygen were added to sintered niobium initially containing about $200 \mathrm{ppm}$ oxygen, by exposing the niobium to oxygen in a modified Sievert's apparatus. Three sets of alloy charges were then prepared: one set was prepared with the original niobium containing $200 \mathrm{ppm}$ oxygen, a second set with niobium containing approximately $1000 \mathrm{ppm}$ 
oxygen, and a third set with niobium containing approximately $3000 \mathrm{ppm}$ oxygen. The charges were prepared to produce alloys of uranium with nominally $10,20,30,40,50$, $52,54,56$, and $58 \mathrm{w} / \mathrm{o}$ niobium. To study the effects of zirconium, alloy charges of compositions niobium $-60 \mathrm{w} / 0$ uranium $-5,-10$, and $-20 \mathrm{w} / 0$ zirconium and niobium $-50 \mathrm{w} / \mathrm{o}$ uranium $-5,-10$, and $-20 \mathrm{w} / \mathrm{o}$ zirconium were prepared. The materials used in these alloys were sintered niobium biscuit, biscuit uranium, and crystal-bar zirconium.

The alloy charges were arc melted seven times for homogeneity and were cast into wire bars. In order to reduce any segregation that may have occurred during the casting of the alloys, the wire bars were annealed in vacuum for $8 \mathrm{hr}$ at temperatures ranging from 1200 to $1600 \mathrm{C}$; the temperature of homogenization was varied depending on the niobium content of the alloy, being increased with increasing niobium content, except for the zirconium-bearing alloys which were all annealed at $1600 \mathrm{C}$.

Specimens for heat treatment were cut from the wire bars, wrapped in tantalum foil, and sealed in Vycor or quartz capsules, which were evacuated and which contained zirconium chips for gettering purposes. The heat treatments were chosen to bracket single-phase and two-phase regions in each group of alloy specimens heated together. The uranium-niobium alloys containing $10 \mathrm{w} / 0$ niobium were heated at temperatures ranging from 725 to $800 \mathrm{C}$ for 1 month, the alloys containing 20,30 , and $40 \mathrm{w} / \mathrm{o}$ niobium were heated at temperatures ranging from 850 to $940 \mathrm{C}$ for 1 month, the alloys containing 50 to $58 \mathrm{w} / 0$ niobium were heated at temperatures ranging from 650 to $750 \mathrm{C}$ for 2 months, and the uranium-niobium-zirconium alloys were heated at temperatures ranging from 500 to $750 \mathrm{C}$ for 3 months. All heat treatments were followed by water quenching.

After heat treatment, the alloys were metallographically examined. It was found that the alloys showed varying degrees of inhomogeneity and displayed dendritic structures; the most severe inhomogeneity was found to occur in the uranium-30 w/o niobium alloys. The uranium-10 w/o niobium alloys contained two phases, but secondphase platelets were distributed over only a small portion of the specimen surface. An attempt was made to utilize an electron-beam microanalyzer to establish the compositions of the gamma 1 matrix, and the gamma 2 platelets. However, the analyses were inconclusive since the gamma2 platelets behaved nearly as two-dimensional surfaces which the electron-beam penetrated, resulting in misleading data. Because of the lack of homogeneity in the alloys, only conclusions which are qualitative in nature could be drawn from the observations.

In general, the structures of the heat-treated binary alloys were in agreement with the composition limits described by the diffusion analyses previously mentioned. Oxygen ranging from 100 to $1000 \mathrm{ppm}$ by analysis for each alloy composition did not appear to appreciably affect the amounts of uranium- or niobium-rich second phase observed in the alloys. However, an additional oxide phase was evident in the alloys to which oxygen had been added. The uranium-20 w/o niobium and uranium-40 w/o niobium alloys contained, respectively, niobium-rich and uranium-rich second phase precipitated at the grain boundaries at temperatures up to $900 \mathrm{C} ; 940 \mathrm{C}$ appeared to be the upper limit for secondphase precipitation in the uranium-30 w/o alloys. At 650 and $750 \mathrm{C}$, the uranium-52 w/o niobium alloys appeared to contain two phases, while the alloys containing $54 \mathrm{w} / 0$ niobium appeared to be single phase.

Alloys of niobium-50 w/o uranium with up to $10 \mathrm{w} / 0$ zirconium consisted primarily of retained gamma with massive transformation products at the grain boundaries. These 
grain-boundary phases were produced by transformation of segregated uranium-rich areas to form alpha uranium and a niobium-rich solid solution. The alloys containing $60 \mathrm{w} / \mathrm{o}$ uranium did not contain grain-boundary transformation products but rather dis played random small areas where transformation had apparently occurred.

\section{CONCLUSIONS}

In reviewing the information presented, the following conclusions can be drawn.

(1) The inability to fabricate alloys containing $30 \mathrm{w} / \mathrm{o}$ or more uranium is probably due to segregation. Although skull melting eliminated banding or macrosegregation, it did not eliminate microsegregation.

(2) Alloys of niobium containing 4.38 through $20 \mathrm{w} / \mathrm{o}$ uranium are much stronger in the 1600 to $2400 \mathrm{~F}$ range than a number of commonly used structural materials.

(3) Contamination by oxygen results in increased tensile and creep strength up to $1600 \mathrm{~F}$ and reduced tensile elongation at temperatures up to $2200 \mathrm{~F}$.

(4) Creep tests of the niobium-uranium alloys indicate that high creep strength can be expected even at $2000 \mathrm{~F}$.

(5) Niobium-uranium alloys are compatible with $\mathrm{NaK}$ (1600 F) and sodium (1500 F). The slight attack which is noted in these liquids is due to the oxygen in the $\mathrm{NaK}$ and sodium.

(6) The resistance of the niobium-uranium alloys to corrosion by 600 and $680 \mathrm{~F}$ water is adequate for a fuel material. Although there is some attack a cladding failure would not be expected to lead to catastrophic failure of the fuel.

(7) Alloying with 10 and $20 \mathrm{w} / 0$ uranium decreases the thermal conductivity of unalloyed niobium in a manner typical of solidsolution alloys. A Wiedemann-Franz relation was developed which should allow reasonable predictions of the thermal conductivity of niobium-uranium alloys from electrical-resistivity data. The electrical resistivity of niobium is increased by the addition of 10 and $20 \mathrm{w} / \mathrm{o}$ uranium. Neither 10 nor $20 \mathrm{w} / \mathrm{o}$ uranium affect the the rmal-expansion behavior of niobium significantly.

(8) Recrystallization temperatures for alloys containing from 5 to $30 \mathrm{w} / 0$ uranium range from 2200 to $2400 \mathrm{~F}$. High oxygen contamination appears to promote stress relief without recrystallization. 
(9) Oxygen additions produce no significant changes in niobiumuranium alloy constitution in the vicinity of the gamma immiscibility gap aside from the precipitation of oxide in the structure.

As a general conclusion, it can be stated that niobium-uranium alloys possess great promise for use as fuel alloys at elevated temperatures. They exhibit exceptional high-temperature strength and acceptable corrosion resistance to high-temperature water and liquid metals. However, fabricability problems limit consideration to alloys containing $25 \mathrm{w} / \mathrm{o}$ or less uranium.

Current irradiation studies remain to be completed to complete the evaluation of these alloys.

In addition to their promise as fuel alloys, the exceptional strength makes the high niobium ( 4 to $20 \mathrm{w} / 0$ uranium) alloys attractive as a structural material. The alloys mentioned above are readily fabricable, have excellent room-temperature ductility and in general possess a combination of properties rarely obtainable in materials exhibiting high elevated-temperature strength.

\section{ACKNOW LEDGMENTS}

The authors wish to thank Warren Berry for his helpful suggestions in interpretations of the water corrosion data. They would also like to acknowledge the help of Glenn Beatty in the determination of the Wiedemann-Franz relation for the niobiumuranium alloys.

\section{REFERENCES}

(1) De Mastry, J. A., Shober, F. R., and Dickerson, R. F., "Metallurgical Studies of Niobium-Uranium Alloys", BMI-1400 (December 7, 1959).

(2) Murr, W. E., and Melehan, J. B., private communication.

(3) Rough, F.A., and Bauer, A. A., "Constitution of Uranium and Thorium Alloys", BMI-1300 (June 2, 1958).

(4) Dickerson, R. F., Foster, E. L., and Chubb, W., "Segregation in Arc-Melted Uranium-Niobium Alloys", BMI-1218 (August 28, 1957). Confidential.

(5) De Mastry, J. A., Shober, F. R., and Dickerson, R. F., "High-Temperature Niobium-Base Alloys for Sodium-Cooled Reactors", BMI-1513 (April 14, 1961).

(6) Begley, R. T., and Platte, W. M., "Development of Niobium-Base Alloys", WADC TR 57-344, Part IV (February, 1960).

(7) "Steels for Elevated Temperature Service", United States Steel (1949). 
(8) Hastelloy Alloy X, Haynes Stellite Company, Kokomo, Indiana (October, 1957).

(9) "René 41", The Alloy Specialist, Cannon Muskegon Corporation.

(10) Fieldhouse, I. B., Hedge, J. C., and Lang, J. I., "Measurement of Thermal Properties", WADC TR 58-274 (March 1, 1958).

(11) The Metallurgy of Zirconium, National Nuclear Energy Series, McGraw-Hill Book Company, New York (1955), "Corrosion of Zirconium and Its Alloys" (B. Lustman).

(12) Deem, H. W., Wood, W. D., and Lucks, C. F., "Memorandum on the Relationship Between Electrical and Thermal Conductivities of Titanium Alloys" (July 18, 1957).

(13) Niobium Data Manual, E. L. Francis, Comp., IGR-R/R-304 (1958). 